\title{
ESTUDIO DE LA PROACTIVIDAD MEDIOAMBIENTAL EN LAS EMPRESAS INDUSTRIALES DE LA COMUNIDAD VALENCIANA: IDENTIFICACIÓN DE PATRONES DE COMPORTAMIENTO.
}

TESIS DOCTORAL

Doctorando:

D. Conrado Enrique Carrascosa López

Dirigida por:

Dra. D ${ }^{a}$ María del Val Segarra Oña

Dr. D. Baldomero Segura García del Río

Dr. D. Ángel Peiró Signes

Valencia, Julio 2012 


\section{Resumen.}

El concepto de proactividad podría definirse como la tendencia a iniciar cambios de forma voluntaria en lugar de esperar para reaccionar ante posibles presiones. Cuando esta proactividad es encauzada hacia el cuidado del medioambiente, entonces surge el concepto de proactividad medioambiental, que se define como la implementación voluntaria de prácticas e iniciativas animadas a mejorar la relación entre las empresas y el medioambiente. El propósito de esta tesis es estudiar en detalle el concepto proactividad medioambiental en la empresa y su aplicación a las industrias manufactureras que, en muchas ocasiones, observan el medioambiente con recelo. Para ello partimos de una revisión de la literatura sobre proactividad medioambiental, y su aplicación a los distintos tipos de industrias, con el objetivo de verificar su aplicación práctica y su utilidad para las empresas. En el mundo actual en el que aumentar la competitividad de las empresas es un factor fundamental para favorecer su supervivencia, es interesante conocer si la proactividad medioambiental puede ser una fuente de mejora de la productividad en la empresa y, por lo tanto, de su competitividad. Así, el objetivo principal de este estudio es analizar en profundidad el sector industrial desde el punto de vista del comportamiento medioambiental, estudiando la proactividad medioambiental en una zona concreta, en este caso la Comunidad Valenciana. La estructura seguida en la elaboración de esta tesis consiste en el compendio de dos artículos publicados en revistas académicas internacionales que han aplicado evaluación externa anónima, dos capítulos de libros de investigación publicados en una editorial internacional de prestigio y un quinto artículo que actualmente se encuentra en proceso de revisión. Cada uno de ellos aborda cada una de las diferentes fases en las que se ha dividido este estudio, y su conjunto explica el contenido de esta tesis. La estructura de los capítulos que incluyen los artículos es la correspondiente al formato pedido por las revistas para ser revisados y posteriormente publicados.

Esta investigación está dividida en dos fases independientes pero interconectadas entre sí. En la primera fase de estudio se elabora un acercamiento a través de tres estudios de casos empíricos, según una metodología cualitativa, aplicados a los tres sectores industriales más importantes de la Comunidad Valenciana, el sector de la alimentación, el de la cerámica y el del automóvil. En estos tres estudios los objetivos buscados son los siguientes:

1.- Identificación de facilitadores de la proactividad medioambiental.

2.- Identificación de los obstáculos que encuentran dichas empresas para su orientación medioambiental proactiva. 
3.- Identificación de los beneficios que esperan dichas empresas cuando se implican en el comportamiento medioambiental proactivo.

En la segunda fase se realiza un análisis cuantitativo doble para corroborar la información obtenida en los estudios de casos referentes a la identificación de facilitadores de la proactividad medioambiental. En el primer análisis se exploran el tamaño de la empresa y la internacionalización de la misma. En el segundo análisis se explora el compromiso medioambiental de la gerencia.

Se ha encontrado conveniente realizar el estudio en estas dos fases. La primera, para poder ver que ocurre desde el punto de vista interno a través de entrevistas personales en las cuales se observa el comportamiento real de las empresas. Posteriormente, observar que ocurre desde un punto de vista externo a las empresas a través del análisis cuantitativo. El análisis conjunto ofrece la visión amplia objetivo de este estudio y permite contrastar la información obtenida con los estudios de casos, con la información obtenida a través del análisis cuantitativo.

Los resultados de esta investigación permiten conocer patrones de comportamiento de las empresas industriales de la Comunidad Valenciana, de sus facilitadores, beneficios y obstáculos. Con respecto a los facilitadores, las principales conclusiones que se han obtenido son que el tamaño grande de una empresa facilita la proactividad medioambiental, sin embargo también se verifica que el tamaño pequeño no es una barrera infranqueable para el comportamiento medioambiental proactivo. La intenacionalización de la empresa también facilita la orientación medioambiental proactiva, aunque la implicación directa de la gerencia se revela como un factor esencial en las empresas que muestran orientación proactiva hacia el medio ambiente. Los principales obstáculos observados para la proactividad medioambiental son la falta de apoyo financiero y la falta de apoyo institucional. Los principales beneficios consecuencia de un comportamiento medioambiental proactivo son evitar futuras sanciones, seguido de la mejora de la imagen corporativa, y del ahorro de costes a largo plazo.

La conclusión final de esta investigación indica que la proactividad medioambiental puede ser una fuente de valor para las empresas de la Comunidad Valenciana, y que por lo tanto merece la pena su apoyo y su difusión.

Palabras clave: Proactividad medioambiental, sector industrial, desarrollo sostenible, estrategia. 


\section{Resum.}

El concepte de proactivitat podría definirse com la tendència a iniciar canvis de forma voluntaria en lloc de esperar per a reaccionar ante posibles presions. Quan esta proactivitat es dirigeix a l'atenció del mediambient llavors sorgix el concepte de proactivitat mediambiental. Es tracta de la implementació voluntària de pràctiques i iniciatives animades a millorar la relació entre les empreses i el mediambient.

El propòsit d'esta tesi es estudiar el concepte proactivitat mediambiental y la seua aplicació a les industries manufactureres, les quals observen el medi ambient amb recel en moltes ocasions. Es necesari fer una revisió de la literatura en proactivitat mediambiental, y la seua aplicació als distints tipus de industries, l'objectiu es conéixer quines son les últimes tendències en este camp, però sobretot el més important es verificar la seua aplicació pràctica y la seua utilitat per a les empreses. En el món actual en el qual augmentar la competitivitat de les empresas es un factor fonamental per a afavorir la seua supervivència, es interesant conéixer si la proactivitat mediambiental potser una font de millora de la productivitat en la empresa y per tant de la seua competitivitat.

L'objectiu principal de este estudi es analitzar en profunditat el sector industrial des del punt de vista del comportament mediambiental, estudiant la proactivitat mediambiental en la Comunitat Valenciana. L'estructura seguida en la elaboració de esta tesi consisteix en el compendi de dos articles publicats en revistes acadèmiques internacionals que han aplicat avaluació externa anónima, dos capítols de llibre de investigació en editorial internacional de prestigi i un quint article que actualmente es troba en procés de revisió. Cada un dels quals aborda cada una de les diferents fases en què s'ha dividit este estudi, y el seu conjunt explica el contingut de esta tesi. L'estructura dels capítols que inclouen els articles es la corresponent al format demanat per les revistes per a ser revisats y posteriorment publicats.

Esta investigació está dividida en dos fases independents però interconnectades entre si. En la primera fase d'estudi ens acostem per mitjà de tres estudis de casos empírics, segons una metodología qualitativa, aplicats als tres sectors industrials més importants de la Comunitat Valenciana, el sector de l'alimentació, el de la ceràmica i el del automòbil. En els tres estudis els objectius buscats són els següents:

1.- Identificació de facilitadors de la proactivitat mediambiental.

2.- Identificació dels obstacles que troben les empreses per a la seua orientació mediambiental proactiva. 
3.- Identificació dels beneficis que esperen les empreses quan s'impliquen en el comportament mediambiental proactiu.

En la segona fase es realitza una anàlisi quantitativa per a corroborar la información obtinguda en els estudis de cas referents a la identificació de facilitaors de la proactivitat mediambiental. En la primera anàlisi s'exploren la grandària de l'empresa i la internacionalització de la mateixa. En la segona anàlisi s'explora el compromís mediambiental de la gerencia.

S'ha trobat convenient realitzar l'estudi en estes dos fases, la primera es per a poder veure que passa desde dins, per mitjà d'entrevistes personals, en les quals s'observa el comportament real de les empreses. Y posteriorment veure que passa desde fora, per mitjà de la anàlisi quantitativa. L'anàlisi conjunta oferix la visió àmplia objectiu d'este estudi y permet contrastar la informació real obtinguda amb els estudis de casos, amb la información obtinguda per mitjà de la anàlisi quantitativa.

Els resultats d'esta investigació permeten conéixer patrons de comportament de les empreses industrials de la Comunitat Valenciana, dels seus facilitadors, beneficis i obstacles. Respecte als facilitadors, les principals conclusions que s'han obtingut són que la grandària gran d'una empresa facilita la proactivitat mediambiental, no obstant això també es verifica que la grandària xicoteta no és una barrera infranquejable per al comportament mediambiental proactiu. El competir internacionalment també facilita l'orientació mediambiental proactiva i la implicació directa de la gerència és essencial per a facilitar també la dita orientació proactive. Els principals obstacles observats per a la proactivitat mediambiental són la falta de suport financer i la falta de suport institucional. Els principals beneficis conseqüència d'un comportament mediambiental proactiu són evitar futures sancions, seguit de la millora de la imatge corporativa, i de l'estalvi de costos a llarg termini

La conclusió final d'esta investigació indica que la proactivitat mediambiental pot ser una font de valor per a les empreses de la Comunitat Valenciana, i que per tant val la pena el seu suport i la seua difusió

Paraules clau: Proactivitat mediambiental, sector industrial, desenrotllament sostenible, estrategia. 


\begin{abstract}
.
Proactivity concept could be defined as the tendency to initiate changes on a voluntary basis rather than waiting to react to possible pressures. Environmental proactivity appears when this proactivity is focused on environmental care. It is the voluntary implementation of practices and initiatives encouraged to improve the relationship between the company and the environment.
\end{abstract}

The purpose of this thesis is to study the environmental proactivity concept and its application to manufacturing industries, which often regard environment distrustfully. It is therefore necessary a literature review on environmental proactivity and its application to different industrial types, the goal is to know what the latest trends in this field are, but above all the most important is to check its practical application and usefulness for companies. In today's world, increasing enterprises competitiveness is a key factor to promote their survival, it is interesting to know if environmental proactivity can be a source of companys' productivity improvements and therefore their competitiveness can be improved as well.

The main objective of this study is the industrial sectors in-depth analysis from the environmental performance point of view, studying environmental proactivity in the Valencian Community. The structure followed in this research is the collection of two papers published in international academic journals with anonymous review, two chapters of research books in prestigious international editorial, and a fifth paper that is actually in revision process. Each one approaches the different phases in which this study has been divided, and the whole content explains this thesis. Articles internal structure follows each journal's requested format in order to be reviewed and subsequently published.

This research is divided into two separated but interconnected phases. The first phase consists in a qualitative approach through three empirical case studies, according to qualitative methodology, applied to the three major industrial sectors of the Valencian Community, the food industry, the tile industry and the automotive industry. The objectives of this first phase are:

1.- Environmental proactivity facilitators identification.

2.- Environmental proactivity obstacles identification.

3.- Environmental proactivity benefits identification. 
In the second phase, a double quantitative analysis is done in order to corroborate the case studies proposed hypotheses relating to the environmental proactivity facilitators identification. In the first analysis, the ones that refer to firm size and internationalization are explored. In the second one is explored environmental management commitment.

It has been found convenient to carry out the study in these two phases; the first is to see what happens from the inside through personal interviews that let recognize firms' real behavior. And then see what happens from the outside through the quantitative analysis. This combined analysis provides the broad vision and aim of this study and allows contrasting the real information obtained from the case studies with information obtained through the quantitative analysis.

The results of this research allow us to know industrial firms behavior patterns in Valencia, their facilitators, benefits and obstacles. The main conclusion obtained concerning the facilitators are the following; large size of a company facilitates environmental proactivity, but it is also verified that small size is not an insurmonuntable barrier to proactive environmental behavior. International competing also facilitates proactive environmental orientation and direct involvement of management is also essential to provide such a proactive orientation. The major obstacles identified for environmental proactivity are lack of financial support and lack of institutional support. The main benefits resulting from the proactive environmental behavior are to avoid futures sanctions, followed by improvement of corporate image and cost savings in the long term.

The final conclusion of this research indicates that environmental proactivity can be a source of value for companies in the Valencian Community, and therefore it is worth its support and diffusion

Key words: Environmental proactivity, industrial sector, sustainable development, strategy. 


\section{Agradecimientos}

En primer lugar quisiera expresar mi gratitud mis directores $\mathrm{D}^{\mathrm{a}}$ María del Val Segarra Oña, D. Baldomero Segura García del Río y D. Ángel Peiró Signes por su guía, sus consejos y su ayuda en la realización de esta tesis. Especialmente a D ${ }^{a}$ María del Val Segarra Oña, iniciadora y promotora de esta investigación, quisiera agradecer su paciencia, su confianza y sus abundantes dosis de motivación, especialmente cuando mis fuerzas flaqueaban. Sin ella no habría sido posible esta tesis.

Quisiera agradecer al Ministerio de economía y competitividad su apoyo a través del proyecto de investigación (EC02011-27369), a la Universitat Politécnica de Valencia por su apoyo a través del proyecto de investigación (PAID-06-2011-1879) y al Master GEPS. También quisiera mostra mi agradecimiento a las revistas: Environmental Engineering and Management Journal, International Business \& Economics Research y TEC empresarial, y a la editorial Springer-Verlag por la publicación de los diferentes artículos y a sus revisores por sus comentarios y sugerencias.

Muchas gracias a mi querida esposa Maria José, por su paciencia, su ánimo constante, y la sobrecarga familiar que ha llevado sobre sus hombros. Sin ella no habría sido posible esta tesis.

Quisiera dedicar esta tesis a mis queridos hijos, Jesús, Miguel, Pablo y Andrés, y a dos personas que ya no están entre nosotros, a mi querido papá y a mi querida abuela María. 
Índice:

\section{Capítulo 1: Introducción}

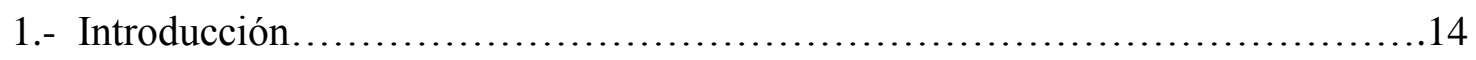

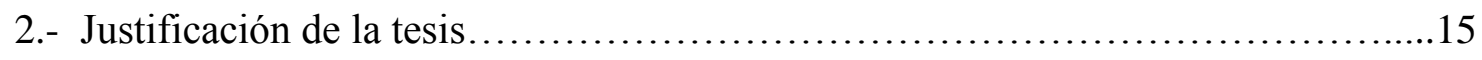

3.- Estructura de la tesis y objetivos de la investigación..................................20

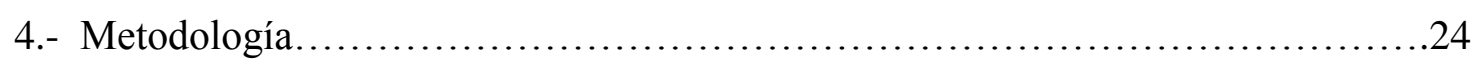

4.1. Descripción del cuestionario para estudio cualitativo......................25

4.2. Descripción de los estudios cuantitativos.................................27

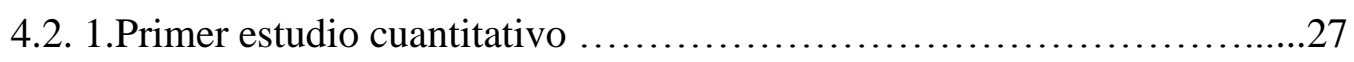



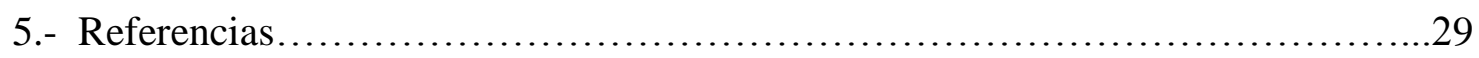

\section{Capítulo 2: Do companies know which are the barriers and facilitators that enable} proactive environmental orientation of the industry? An empirical study of a low tech industry.

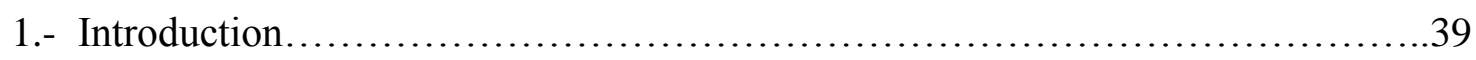

2.- Research approach....................................................... 41

2.1.- Objectives and chapter structure........................................41

2.2.- Review of literature on environmental strategy .........................42

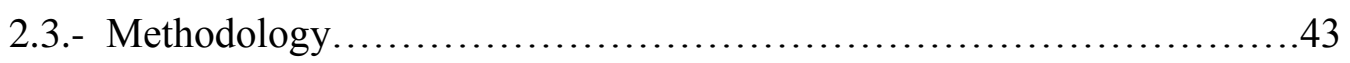

3.- Practical application to the Spanish food sector..................................43

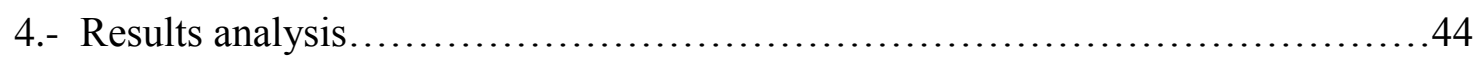

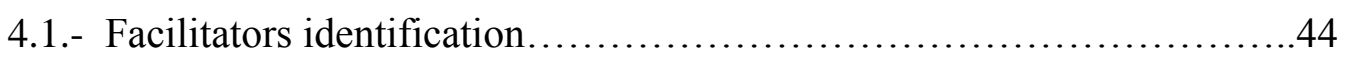

4.2.- Obstacles identification for environmental proactivity...................45

4.3.- Benefits identification for environmental proactivity.....................45

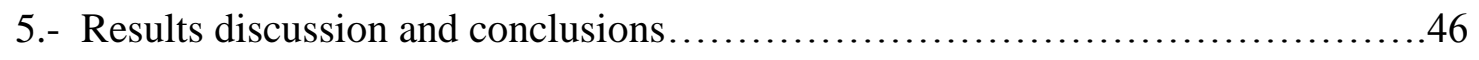

5.1.- Model developed and verification of hypotheses.........................46 
References.

Capítulo 3: Is it possible to generate added value through a higher environmental proactivity orientation? A practical analysis of the Spanish ceramic industry.

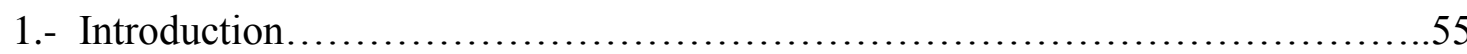

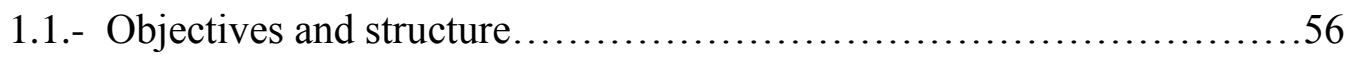

1.2.- Literature review on environmental strategy $\ldots \ldots \ldots \ldots \ldots \ldots \ldots \ldots \ldots . \ldots 56$

2.- General perspective ceramic sector......................................57

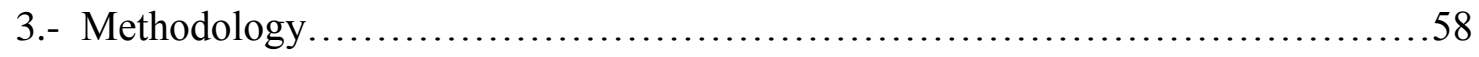

4.- Results analysis..................................................59

4.1.- Facilitators identification........................................59

4.2.- Identification of obstacles to environmental proactivity................60

4.3.- Identification of benefits of environmental proactivity................60

5.- Conclusions and discussion........................................61

5.1.- Modeling results and hypotheses testing.........................61

5.2.- Conclusion....................................................

References..........................................................62

Capítulo 4: Empirical analysis of the integration of environmental proactivity into managerial strategy. Identification of benefits, difficulties and facilitators at the Spanish automotive industry

1.- Introduction......................................................67

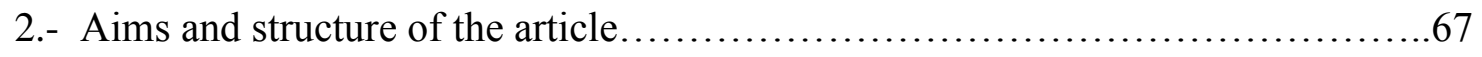

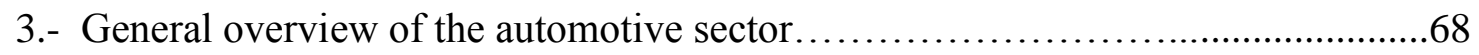

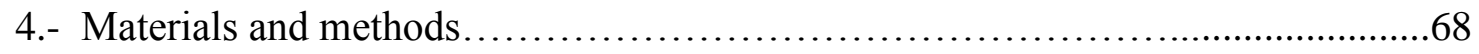

4.1.- Part one: identifying case's studied proactive attitude.................69

4.2.- Part two: empirical data confrontation.................................69

4.3.- The sample..................................................69

5.- Results analysis................................................. 70

5.1.- Results from the qualitative analysis...........................70 
5.1.1.- Identification of factors characterizing the companies environmental performance.................................... 70

5.1.2.- Identification of obstacles to proactive orientation............ 70

5.1.3.- Identification of the benefits of environmental actions..........71

5.2.- Results from the quantitative analysis.............................71

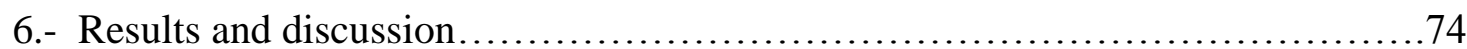

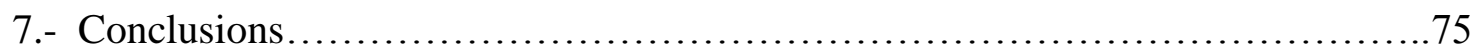

References.................................................................... 75

Capítulo 5: Environmental proactivity applied to manufacturing industries. Is it valuable?

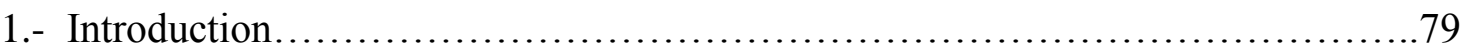

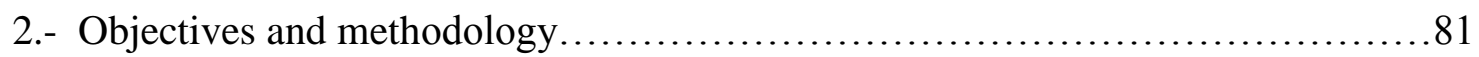

3.- Three case studies. Most important industrial sectors of Valencian Community...81

3.1.- Automotive sector case study.................................... 81

3.2.- Food industry case study......................................... 81

3.3.- Tile industry case study........................................ 82

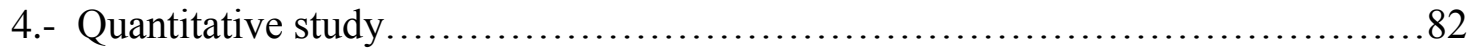

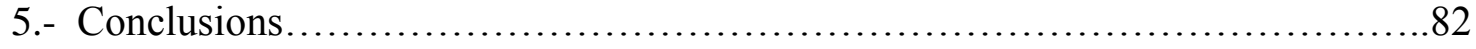

6.- References.............................................................. 83

Capítulo 6: Explorando la relación entre mejora continua, innovación y compromiso medioambiental de la gerencia, un estudio empírico

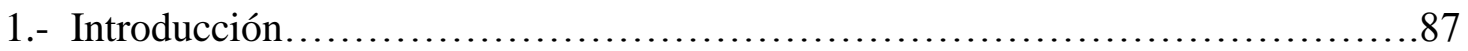

2.- Revisión de literatura...................................................... 88

3.- Muestra y metodología................................................91

4.- Análisis y resultados................................................. 95

5.- Conclusiones............................................................. 99

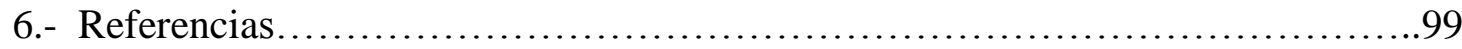

\section{Capítulo 7: Discusión de resultados y conclusiones}

1.- Introducción. 
2.- Resultados............................................................. 104

3.- Conclusiones.......................................................... 114

4.- Limitaciones......................................................... 118

5.- Futuras líneas de investigación.........................................118

6.- Referencias................................................................ 119

\section{Capítulo 8: Anexos}

1.- Cuestionario de evaluación de la proactividad medioambiental..................121



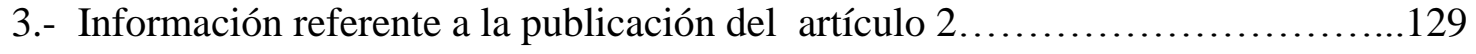

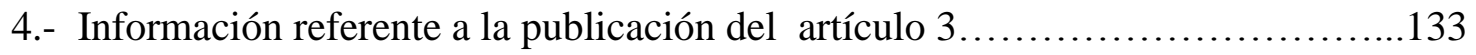

5.- Información referente a la publicación del artículo $4 \ldots \ldots \ldots \ldots \ldots \ldots \ldots \ldots \ldots \ldots \ldots \ldots$

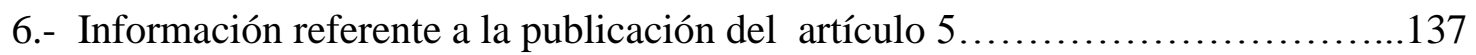




\section{CAPÍtULO 1}

INTRODUCCIÓN 


\section{1.- Introducción}

La motivación principal de esta tesis es profundizar en el concepto de la proactividad medioambiental y estudiarla desde el punto de vista de las empresas industriales, en un estudio aplicado fundamentalmente a la Comunidad Valenciana, en el cual se explica cual es el comportamiento de sus industrias con respecto a la proactividad medioambiental y que patrones se pueden identificar en el mismo. Por ello se titula esta tesis "Estudio de la proactividad medioambiental en las empresas industriales de la Comunidad Valenciana:

\section{Identificación de patrones de comportamiento"}

La presente tesis está compuesta por ocho capítulos. El primer capítulo se corresponde con la introducción. El segundo y el tercer capítulo se corresponden con dos capítulos de libros de investigación publicados en editorial internacional de prestigio. El cuarto capítulo se corresponde con un artículo publicado en una revista internacional que ha aplicado evaluación externa anónima. El quinto capítulo se corresponde con un artículo que ha sido aceptado para su publicación en otra revista internacional con evaluación externa anónima. El sexto capítulo es un artículo que se encuentra actualmente en proceso de revisión. El séptimo capítulo presenta los resultados y las conclusiones obtenidas con este estudio. En el octavo capítulo se adjuntan en los anexos la encuesta que ha conducido los estudios de caso y la información correspondiente a la publicación de los capítulos de libro de investigación y de revistas académicas.

Este primer capítulo introductorio está formado por 5 apartados. Después de esta introducción, que es el primer apartado, en el segundo se muestra el estado del arte del concepto proactividad medioambiental en la literatura académica, presentando cual es el "Research gap" que justifica la presente tesis. En el tercer apartado se explica la estructura de la tesis, sus objetivos y el hilo conductor de los cinco artículos. En el cuarto apartado se explica la metodología utilizada en cada una de las fases de este estudio, el origen de los datos con los que se ha materializado, así como sus características y procedencia. En el quinto apartado se muestran todas las referencias bibliográficas utilizadas en el conjunto de los cinco artículos. 


\section{2.- Justificación de la tesis.}

Se podría definir el concepto de proactividad como la tendencia voluntaria a iniciar cambios, en lugar de esperar y reaccionar a los acontecimientos. Proactividad estratégica es la habilidad de las empresas para iniciar cambios en sus políticas en lugar de reaccionar ante los acontecimientos (Aragón- Correa, 1998). Se define el término proactividad empresarial, como aquel comportamiento que consiste en tomar la iniciativa para la mejora de las circunstancias de cualquier campo de la empresa (Crant, 2000). Si esta proactividad es aplicada al cuidado del medioambiente, se refiere entonces a proactividad medioambiental, se trata de la implementación voluntaria de prácticas e iniciativas que conducen a mejorar la relación de la empresa con el medioambiente (González-Benito, González-Benito, 2006).

Los factores determinantes de la proactividad medioambiental pueden clasificarse en internos de la empresa o externos a ella. Los internos son: el tamaño de la empresa, el formar parte de una corporación internacional y el apoyo y compromiso de la alta gerencia. Los factores externos a la empresa son: el sector industrial al que se pertenece, ya que cada industria tiene un potencial diferente de polución y está sujeta a diferentes controles por parte de las administraciones públicas, instituciones y consumidores, y la localización, ya que de ella dependen tanto la legislación medioambiental como la presión social (González-Benito, González-Benito, 2006). De entre estos determinantes, el considerado central y esencial para el desarrollo de estrategias medioambientales proactivas es la presión y compromiso de los accionistas (González-Benito, González-Benito, 2010). Aragón-Correa et al., (2008) estudió las pequeñas y medianas empresas, para verificar que el tamaño de la empresa es relevante, pero no una condición determinista que impida desarrollar estrategias medioambientales proactivas. La relación entre la presión del accionariado y las prácticas medioambientales proactivas varían con respecto al tamaño de las empresas. Las empresas pequeñas son más sensibles a dichas presiones percibidas, y éstas repercuten en un mejor comportamiento medioambiental (Darnall et al., 2010). En relación a las presiones hacia las empresas, Gadenne et al., (2009) observa que, a pesar de encontrar empresas con accionistas / gerentes con actitudes "verdes", el nivel de implementación de prácticas medioambientales en dichas empresas era pobre.

La capacidad de generar una actitud estratégica proactiva es dinámica, y es importante para su generación el entorno de la empresa. Esta generación de la estrategia proactiva del medioambiente puede ser facilitado o dificultado por la empresa y su entorno (AragónCorrea, Sharma, 2003). Se puede influir en la motivación proactiva a través de la concienciación sobre los potenciales beneficios que pueden suponer las prácticas 
medioambientales (Gadenne et al., 2009). Por ello, el comportamiento medioambiental proactivo de una misma empresa puede variar con el tiempo. Las empresas que mejoran su comportamiento medioambiental significativamente, previamente han mejorado sus recursos financieros y / o la capacidad de gestión de su gerencia. De forma análoga, aquellas cuyo comportamiento medioambiental proactivo empeora, previamente han sufrido una merma en sus recursos financieros y/o la capacidad de gestión de su gerencia (Clarkson et al., 2011).

En cuanto a la influencia externa, hay estudios que analizan los diferentes patrones de respuesta medioambiental ante la influencia de la presión de los diferentes agentes sobre las empresas (Murillo-Luna et al., 2008). Por ejemplo, el rol de los clientes en las presiones medioambientales, observando la diferencia en la respuesta medioambiental entre empresas con posiciones diferentes en la cadena de suministro, concretamente entre las empresas B2B (Business to business) o las C2C (Close to consumer). Este estudio concluye que la presión recibida $\mathrm{y}$, por tanto, el comportamiento, es mejor entre las empresas cercanas al consumidor que entre las B2B (Haddock-Fraser, Tourelle, 2010).

Es necesario mirar más allá de la superficie de la empresa, para comprender mejor cuáles son las capacidades que apoyan la aparición de estrategias sostenibles con éxito, considerando fundamental en este proceso el concepto de capacidad de absorción (Delmas et al., 2011). Así mismo, no siempre el hecho de mostrar actitudes favorables hacia el medioambiente está asociado con la toma de acciones para mejorar el impacto medioambiental de la empresa, por lo que se recomiendan los estudios empíricos (Gadenne et al. 2009).

Para medir el grado de proactividad medioambiental de una empresa se considera necesario medir la implementación de diversas prácticas medioambientales. Así mismo, es necesario aproximarse empíricamente para poder medir los efectos comparativos de aquellos factores que afectan al comportamiento medioambiental en la empresa y así poder determinar cuál es la influencia de cada una de ellos (González-Benito, González-Benito, 2006; AragónCorrea, Sharma, 2003). Entre estas formas de medida se encuentra la Australian Environmental Attitude Scale, la cual compila las respuestas de una serie de preguntas en un cuestionario del tipo escala Likert sobre las actitudes medioambientales observadas, utilizada por Gadenne et al. (2009) en su estudio.

Existen estudios en los que se relaciona la proactividad medioambiental de la empresa con la obtención de diferentes beneficios. Por ejemplo, (Aragón-Correa (1998) define los efectos positivos de la proactividad medioambiental como una nueva área de ventaja competitiva. Hay situaciones en las que el comportamiento proactivo produce beneficios 
tanto para el medio ambiente como para la empresa (King y Lenox, 2001). Los estudios cada vez van concretando y analizando cada uno de los beneficios obtenidos, como la mejora en la reputación de la empresa (Buysse y Verbeke, 2003). El estudio de Gonzalez-Benito y González-Benito (2005), revela que algunas facetas de proactividad medioambiental conducen a efectos positivos tanto en el propio desempeño de la empresa así como en las actividades de marketing. En el estudio de Gadenne et al. (2009) se añaden y detallan más beneficios para las empresas, entre los que se encuentran: reducción de desechos, ahorro de costes, aumento de la satisfacción de los clientes, mejoras en los productos y en las relaciones públicas de las empresas. Los estudios más recientes en este campo añaden que la proactividad medioambiental es una ayuda para los procesos de internacionalización (Martín-Tapia et al, 2010) e incluso para mejorar en los recursos financieros (Clarkson et al., 2011)

Se han encontrado estudios que, buscando relaciones entre la proactividad medioambiental y los efectos económicos beneficiosos para la empresa, exploran la relación entre los sistemas de gestión medioambiental y la creación de valor. Por ejemplo un estudio de caso en el que verifica que adoptar el espíritu de la ISO 14001 provoca cambios en la empresa que se transforman en beneficios para ella (Rondinelli, Vastag, 2000). El estudio de Melnyk et al. (2003) en un estudio más amplio del sector industrial en USA, demuestra que la certificación ISO 14001 conlleva beneficios reales. Darnall et al. (2008) en su estudio basado en una muestra del sector industrial de Canadá, Alemania, Hungría y Estados Unidos, encuentra evidencia empírica del potencial valor de negocio creado en empresas que han implementado sistemas de gestión medioambiental. En España, Segarra et al.(2011a) revelan la misma relación positiva en el sector industrial de la alimentación.

Hay autores críticos con una visión excesivamente positiva del término proactividad medioambiental, conforman la línea de investigación que cuestiona en cierta medida la hipótesis "pays to be green", que relaciona un mejor desempeño medioambiental con recompensas económicas directas. Sharfman y Fernando (2008) indican que los estudios más positivos coinciden para tipos de empresas con riesgo medioambiental, un comportamiento medioambiental positivo disminuye el riesgo y por lo tanto el mercado recompensa dicha disminución, indican que esto no es siempre aplicable para todo tipo de empresas. King y Lenox (2001) argumentan que varios estudios que asocian un mejor comportamiento medioambiental con un mejor comportamiento financiero, con frecuencia carecen de la suficiente información longitudinal necesaria para verificar dicha relación. Afirman que no se puede responder con claridad si conviene "ser verde" en un sector o si conviene operar en sectores "verdes". Por ello se sugiere que la pregunta más importante debería ser ¿cuando 
conviene "ser verde"?. La estrategia proactiva hacia el medio ambiente y su relación con la obtención de ventajas competitivas no siempre puede ser positiva, depende de la influencia de diferentes características del entorno empresarial en general, como la incertidumbre, la complejidad y la generosidad (Aragón-Correa y Sharma, 2003). No siempre se han podido encontrar evidencias de que la proactividad medioambiental asegurara una mayor rentabilidad, por lo menos a corto plazo (González-Benito y González-Benito, 2005). El primer paso para contestar a la pregunta ¿cuando conviene ser verde?, requiere la clasificación de las inversiones relativas al medio ambiente de acuerdo con su potencial para la obtención de ventaja competitiva. Orsato (2006) establece cuatro tipos de estrategias medioambientales, e indica cual sería la ventaja competitiva que se podría obtener en cada una de ellas.

La estrategia proactiva de una empresa puede ser facilitada o dificultada por ciertas dimensiones del entorno de la empresa (Aragón-Correa, Sharma, 2003). Se han encontrado pocas referencias en cuanto a las dificultades que tienen las empresas que quisieran tener un comportamiento medioambiental más proactivo, siendo la falta de recursos financieros una de las mayores barreras que dificultan el desarrollo de prácticas medioambientales (Gadenne et al., 2009).

El formato utilizado con más frecuencia para estudiar el concepto proactividad medioambiental en la literatura académica actual es a través de estudios cuantitativos basados en encuestas o entrevistas. Muchos de estos estudios cuantitativos tienen en común similares características de la muestra, se trata de grupos de empresas pertenecientes a diferentes sectores cuyo único nexo común es operar dentro del mismo país (Aragón-Correa, 1998; Buysse y Verbeke, 2003; Dias Sardinha y Reijnes, 2005; Gadenne et al., 2009; HaddockFraser y Tourelle, 2010; King y Lenox, 2001; Melnyk et al., 2003). A través de estos estudios se han estudiado muestras de empresas en España, Bélgica, Portugal, Australia, Reino Unido y Estados Unidos. También se ha encontrado incluso un estudio referido a muestra de empresas de varios países, Canadá, Estados Unidos, Alemania y Hungria (Darnall et al., 2008).

González-Benito y González-Benito (2006) afirman que los factores externos a las empresas, determinantes de la proactividad medioambiental, son la localización, ya que de ella dependen tanto la legislación medioambiental como la presión social; y el sector industrial al que se pertenece, ya que cada industria tiene un potencial diferente de polución y está sujeta a diferentes controles por parte de las administraciones públicas. Siguiendo esta línea, se han encontrado trabajos que se enfocan hacia un solo sector. Por ejemplo, Martín-Tapia et al. 
(2010) hacia el sector alimentación, González-Benito y González-Benito (2005 y 2010) hacia los sectores químico, electrónico y del mueble. De este modo se evitan las posibles distorsiones que pueden existir debidas a las diferentes peculiaridades que cada sector tiene.

Sin embargo en España se ha encontrado un hecho de relevancia que no se ha tomado en cuenta en estos estudios a nivel nacional, es que la legislación medioambiental no es la misma en todo el país, ya que una parte de ella ha sido transferida como competencia a las comunidades autónomas. Considerando esta cuestión, Murillo-Luna et al. (2008) basan su estudio en una muestra de empresas de la Comunidad Autónoma de Aragón, pertenecientes a diferentes sectores industriales. Por esta razón se aconsejan en el caso particular español, los estudios regionales, para de este modo evitar la posible distorsión provocada por las diferencias respecto las diferentes legislaciones medioambientales autonómicas.

Cuando el objetivo es analizar en profundidad, buscando comprender de cerca el comportamiento de las empresas, para así poder centrarse en los factores internos a ella, se aconseja en este caso fijar tanto el sector industrial al que se pertenece, así como uniformidad en la legislación y presión sociales. Este es el marco a través del cual Aragón-Correa et al., (2008) estudian el sector de reparación de automóviles en tres provincias de Andalucía; Málaga, Granada y Almería.

La principal justificación de esta tesis es que no se han encontrado estudios sobre proactividad medioambiental aplicados a la Comunidad Valenciana. La cercanía geográfica y el interés por estudiar la industria cercana a nuestro alrededor podría haber sido una razón de suficiente peso para enfocar el estudio a la Comunidad Valenciana, pero no ha sido ésta la única razón para tomar esta decisión. Se ha tenido en cuenta según la literatura antes expuesta, las dos consideraciones de elementos externos a las empresas con influencia en la proactividad medioambiental, el mantener una legislación común para la muestra a estudiar, y separar el estudio por sectores industriales para evitar en la medida de lo posible las diferencias entre ellos. Se ha optado por realizar un análisis independiente para cada sector de los estudiados. La elección de los sectores a estudiar se ha basado en su importancia en cuanto al nivel exportador, por ello se han elegido los sectores de automoción, cerámica y alimentación.

La proactividad medioambiental es un término que cada vez está tomando más importancia, y es necesario establecer las bases para su mejor comprensión, que permita conocer los patrones de comportamiento de sus elementos de influencia. El mejor conocimiento de los elementos de un engranaje, y su adecuada dimensión, permiten un uso 
más eficiente de los recursos y posibilita el mejor aprovechamiento de los potenciales beneficios de su aplicación.

\section{3.- Estructura de la tesis y objetivos de la investigación.}

El objetivo principal de este estudio es analizar en profundidad el sector industrial desde el punto de vista del comportamiento medioambiental, estudiando la proactividad medioambiental en la Comunidad Valenciana.

La estructura seguida en la elaboración de esta tesis consiste en el compendio de varias publicaciones, cada una de ellas aborda cada una de las diferentes fases en las que se ha dividido este estudio, y su conjunto explica el contenido de esta tesis. La estructura de los capítulos que incluyen los artículos es la correspondiente al formato pedido por las revistas para ser revisados y posteriormente publicados. Para ello se han elegido tres sectores industriales de los más representativos en la Comunidad Valenciana, y se han realizado tres estudios independientes, cada uno de ellos enfocado a uno de ellos, el sector de la alimentación, el de la cerámica y el del automóvil.

Se comienza analizando el sector de la alimentación, y los objetivos buscados para este sector son los siguientes:

1.- Identificación de facilitadores de la proactividad medioambiental. Este objetivo se subdivide en tres partes:

1.1.- Comprobar la relación entre el tamaño de la empresa y su proactividad medioambiental para el sector de la alimentación.

1.2.- Comprobar la relación entre la internacionalización de las empresas y su proactividad medioambiental para las empresas del sector de la alimentación.

1.3.- Comprobar la relación entre el compromiso medioambiental de la gerencia y la proactividad medioambiental de las empresas del sector de la alimentación.

2.- Identificación y ponderación según su importancia de los obstáculos para la proactividad medioambiental para el sector de la alimentación.

3.- Identificación y ponderación según su importancia de los beneficios esperados tras la proactividad medioambiental para las empresas del sector de la alimentación. 
En el capítulo 2 de la tesis se abordan estos objetivos para el sector de la alimentación. Se presentó como artículo en 5th International Symposium on Information Technologies in Environmental Engineering ITEE 2011 en Poznan en Julio 2011. Posteriormente se le dio la forma de capítulo de libro y ha sido publicado por la editorial Springer Berlin Heidelberg bajo el título: "Do companies know which are the barriers and facilitators that enable proactive environmental orientation of the industry? An empirical study of a low tech industry". El título del libro del que forma parte es "Information Technologies in Environmental Engineering New Trends and Challenges." Este libro forma parte de una colección llamada "Earth and Environmental Science". Copyright Year 2011

DOI 10.1007/978-3-642-19536-5

ISBN 978-3-642-19535-8 (Print) 978-3-642-19536-5 (Online).

A continuación se analiza el sector de la cerámica, y los objetivos buscados para este sector son los siguientes:

4.- Identificación de facilitadores de la proactividad medioambiental. Este objetivo se subdivide en tres partes:

4.1.- Comprobar la relación entre el tamaño de las empresas y su proactividad medioambiental en el sector de la cerámica.

4.2.- Comprobar la relación entre la internacionalización de la empresa y su proactividad medioambiental para el sector de la cerámica.

4.3.- Comprobar la relación entre el compromiso medioambiental de la gerencia y la proactividad medioambiental de las empresas del sector cerámico.

5.- Identificación y ponderación según su importancia de los obstáculos para la proactividad medioambiental en el sector cerámico.

6.- Identificación y ponderación según su importancia de los beneficios esperados tras la proactividad medioambiental en el sector cerámico.

En el capítulo 3 de la tesis se abordan estos objetivos correspondientes al sector cerámico. El artículo resultado se presentó en el congreso ICOVACS 2010, que tuvo lugar en Valencia en Noviembre de 2010, bajo el título: "Environmental proactivity as a value generating element: an application to the spanish ceramic industry". Posteriormente se le 
dio la forma de capítulo de libro y ha sido publicado por la editorial Springer bajo el título: "Is it possible to generate added value through a higher environmental proactivity orientation? A practical analysis of the Spanish ceramic industry.". El título del libro del que forma parte es "EcoProduction \& Logistics - emerging trends and business practices". Está prevista su publicación en Junio de 2012 bajo el ISBN 978-3-642-23552-8

Por último se analiza el sector del automóvil, y los objetivos buscados para este sector son los siguientes:

7.- Identificación de facilitadores de la proactividad medioambiental. Este objetivo se subdivide en tres partes:

7.1.- Comprobar la relación entre el tamaño de las empresas del sector del automóvil y su proactividad medioambiental.

7.2.- Comprobar la relación entre la internacionalización de las empresas del sector del automóvil y su proactividad medioambiental.

7.3.- Comprobar la relación entre el compromiso medioambiental de la gerencia y la proactividad medioambiental de las empresas del sector del automóvil.

8.- Identificación y ponderación según su importancia de los obstáculos para la proactividad medioambiental en el sector del automóvil.

9.- Identificación y ponderación según su importancia de los beneficios esperados tras la proactividad medioambiental en el sector del automóvil.

Este estudio sectorial se enfocó de forma diferente, mientras que los dos anteriores se habían realizado en una sola fase de estudio cualitativo, este estudio sobre el sector del automóvil se realiza en dos fases, la primera cualitativa idéntica a los anteriores es complementada con un análisis cuantitativo sobre una muestra más amplia. Los objetivos de dicho estudio cuantitativo son los siguientes:

10.- Comprobar la relación entre el tamaño de la empresa y su proactividad medioambiental a través del estudio cuantitativo.

11.- Comprobar la relación entre la internacionalización de la empresa y su proactividad medioambiental a través del estudio cuantitativo. 
Este estudio se realizó en forma de artículo y fue presentado en la 4th International Conference on Tourism \& Environment en Cáceres en Septiembre de 2011. Posteriormente este artículo ha sido publicado por la revista Environmental Engineering and Management Journal bajo el título: "Empirical analysis of the integration of environmental proactivity into managerial strategy. Identification of benefits, difficulties and facilitators at the Spanish automotive industry".

ISSN:1582-9596, On-line ISSN:1843-3707, volumen 10 (número 12, diciembre 2011), comprendiendo las páginas 1821 hasta 1830 . Dicha revista se encuentra incluida en la base de datos del ISI Thompson como JCR en el SCIENCE CITATION INDEX, con un factor de impacto de 1.435 en 2010.

Con los tres estudios de caso se obtiene una imagen bastante completa de la proactividad medioambiental y de sus patrones de comportamiento en cada sector industrial. Entonces cobran sentido los siguientes objetivos:

12.- Comparación intersectorial de los patrones de comportamiento y observación de sus similitudes o diferencias entre ellos.

13.- Otro objetivo de esta investigación, a modo de conclusión final, es confirmar si la proactividad medioambiental, además de evidentemente ser buena para el medioambiente, puede proporcionar beneficios a las empresas estudiadas del tejido industrial de la Comunidad Valenciana.

Para ello se contrastará el estudio según la corriente que no está tan a favor de la proactividad medioambiental y que cuestiona en ocasiones la hipótesis "Pays to be green" (Conviene ser verde) en algunas circunstancias. Se verificará si se dan las condiciones que dicha corriente propone para poder beneficiarse del comportamiento medioambientalmente proactivo o no. El objetivo es verificar si merece la pena aconsejar y fomentar la proactividad medioambiental para las empresas de los entornos estudiados. Ya que con frecuencia existe la visión del cuidado medioambiental como si fuera una carga pesada impuesta por la sociedad, exenta de beneficios para la propia empresa. Comparando el estudio desde el punto de vista de la literatura a favor y desde el punto de vista de la que se está en contra, se obtiene una mayor confianza en las conclusiones obtenidas. (Dubé y Paré, 2003). 
En el capítulo 5 de la tesis se abordan estos objetivos. Como resultado del desarrollo de estos objetivos se obtiene el artículo "Environmental proactivity applied to manufacturing industries. Is it valuable?". Presentado en Orlando International Academic Conference en Enero 2012 y posteriormente aceptado para su publicación en la revista International Business \& Economics Research Journal el 2 de Marzo de 2012.

Por último se aborda la figura de la gerencia y su importancia para la proactividad medioambiental de la empresa. Se opta por complementar la información obtenida a través de los estudios de caso cualitativos con un estudio a través de técnicas cuantitativas, con el objetivo siguiente:

14.- Verificar la relación existente entre el compromiso medioambiental de la gerencia y las actividades de mejora continua e innovación. El objetivo es comprobar si proactividad medioambiental, innovación y mejora continua son tres herramientas que convergen hacia una meta común, la mejora de la competitividad.

En el capítulo 6 de esta tesis se aborda este objetivo. El artículo resultado fue presentado en la modalidad poster en el Taller de estrategia empresarial 2012 ACEDE, bajo el título "Explorando la relación entre mejora continua, innovación y compromiso medioambiental de la gerencia, un estudio empírico”. Además se encuentra en revisión para su publicación en la revista TEC empresarial. Emitida por la Escuela de Administración de empresas del Instituto Tecnológico de Costa Rica. Esta revista está indexada en Latindex, Dialnet, CLASE y EBSCO.

\section{4.- Metodología.}

La mayoría de estudios aplicados encontrados sobre proactividad medioambiental son cuantitativos de tamaño de muestra relativamente grande, estos estudios permiten observar relaciones entre distintas variables. La forma de obtención de información es a través de encuestas enviada por correo o cualquier otra forma, en la que se le pide a la empresa que conteste y envíe la respuesta con posterioridad. Estos envíos masivos de encuestas, son generalmente respondidos en un porcentaje muy bajo. En bastante menor cantidad, también se han encontrado algunos estudios cualitativos, con tamaño de muestra menor, pero que permiten un análisis más profundo, permitiendo acercarse hasta las causas.

Gadenne et al. (2009) afirma que empresas con actitud aparentemente "verde", sin embargo tienen un nivel de prácticas medioambientales pobre y por eso recomienda los 
estudios cercanos. Pensamos que, cuando se pregunta a empresas sobre su impacto medioambiental, estas tienden a mostrar en algunas ocasiones una imagen más "verde" que la propia realidad.

En la presente tesis pretendíamos hacerlo de forma diferente, y en lugar de enviar las encuestas y esperar a la respuesta, optamos por realizar las encuestas de forma personal, concertando una cita. Las entrevistas se concertaban con la persona responsable del departamento medioambiental, si lo había, o con la persona encargada de dichas tareas. Sucedía en el caso de empresas pequeñas, que dicha figura no existía, y que esta responsabilidad recaía directamente en el gerente de la empresa. En las entrevistas se pasaba personalmente un cuestionario diseñado por los autores, para caracterizar las empresas en su nivel de proactividad medioambiental, y evaluar su desempeño. Además se recogía información cualitativa que servía para verificar y ampliar lo contestado en el cuestionario, a través de charlas informales con trabajadores de la empresa, identificando información interna, observando los productos o los procesos de fabricación de la empresa. Las respuestas eran rellenadas por el investigador directamente. El investigador además anotaba cualquier otra información relevante obtenida de forma indirecta. Esto limitaba el número de casos a estudiar a un número menor, pero por otro lado permite mayor profundidad y veracidad en las respuestas.

El objetivo principal de la presente tesis es el estudio en profundidad de la proactividad medioambiental aplicada en los sectores industriales, por esta razón se optó en sus estadios iniciales por el análisis cercano, personal y profundo a través de estudios de caso empíricos. De esta forma se llevaron a cabo tres estudios de caso realizados a tres sectores industriales diferentes, en los cuales se estudia la proactividad medioambiental, sus factores motivadores, así como los beneficios obtenidos a través de ella. Dichos sectores son los principales sectores industriales de la comunidad valenciana, el sector de la alimentación, el sector de la cerámica y el sector del automóvil.

\subsection{Descripción del cuestionario para el estudio cualitativo.}

En base a la literatura estudiada, se ha elaborado un cuestionario de respuestas simples y escala tipo Likert, con 5 alternativas respuesta, más una adicional para indicar que no se dispone de criterios suficientes para responder, que serán cumplimentados personalmente por un técnico-investigador en la empresa considerada en cada momento. El análisis del factor 
medioambiental como aspecto proactivo de la dirección de empresas es un fenómeno complejo en el que intervienen multitud de determinantes.

El cuestionario está formado por un total de 42 preguntas divididas en tres grandes apartados. En el primer Bloque, Caracterización, se recopilan los datos básicos de la empresa con una serie de preguntas de respuesta sí/no (dicotómicas), incluyendo además la posibilidad de responder de manera abierta, con el objetivo de determinar si la empresa cuenta con elementos organizativos propios de gestión medioambiental. En el resto de bloques, se utilizar una escala tipo Likert para conocer el grado de acuerdo de los gestores con las afirmaciones propuestas. El intervalo propuesto varía entre 1 (Totalmente en desacuerdo) y 5 (Totalmente de acuerdo), ya que un diseño escalar es preferible a una dicotomía o variable discreta cuando la naturaleza del concepto por el que se pregunta es complejo (Arroyo, 2009).

El segundo bloque incide en identificar los aspectos que permitan caracterizar la empresa en su nivel de proactividad medioambiental. Para elaborar las preguntas de los siguientes bloques del cuestionario se han considerado los factores identificados por Banejee (2003), González Benito et al (2006), con el objetivo de evaluar aquellas variables que se erigen como principales determinantes de la proactividad medioambiental.

El tercer gran apartado trata de identificar aquellos aspectos de la organización que permitan el establecimiento de un sistema de medida de la integración en la estrategia empresarial de la proactividad medioambiental. Se analizan aspectos relacionados con la capacidad de influir en las decisiones de la empresa, la importancia de la protección ambiental, aspectos relacionados con la toma de decisiones ambientales, los obstáculos con los que la empresa se puede encontrar y los beneficios que le puede reportar la gestión ambiental.

En el bloque 3 se hace hincapié en la innovación medioambiental, entendida como aquella que contribuye a la sostenibilidad del entorno natural (Faber y Frenken, 2008) ya que la innovación tecnológica en este campo aún está muy limitada en el campo del análisis económico aunque, desde nuestro punto de vista, representa un elemento diferenciador de gran importancia en la creación y sostenibilidad de ventajas competitivas.

La pregunta 32 trata de cuantificar lo que Shrivastava (1995) llama "desarrollo ecológico sostenible" y "estrategia de nicho ecológicamente sostenible" para conseguir una ventaja competitiva.

Los resultados de esta parte de la investigación se materializan en unas tablas con porcentajes. En la parte correspondiente a los facilitadores, dichos porcentajes representan el 
resultado de la evaluación medioambiental de las empresas, en la que se evalúan los diferentes aspectos correspondientes a su comportamiento medioambiental. En la parte correspondiente a los obstáculos, los porcentajes muestran la importancia de ellos para las empresas. En la parte correspondiente a los beneficios, los porcentajes muestran las posibilidades de obtención de beneficios esperadas después del comportamiento medioambiental proactivo.

\subsection{Descripción de los estudios cuantitativos.}

Después de realizar el estudio de caso cualitativo sobre el sector del automóvil, se planteó la posibilidad de complementarlo a través de un estudio cuantitativo realizado sobre una muestra mayor. El objetivo no era otro sino contrastarlo con los resultados obtenidos anteriormente y de esta forma reforzar las hipótesis planteadas en el estudio previo. Para ello se plantearon en el estudio cuantitativo la relación entre el tamaño de la empresa y su internacionalización con la proactividad medioambiental.

Posteriormente se vió recomendable la realización asimismo de un estudio cuantitativo que pudiera a su vez complementar y reforzar los resultados obtenidos sobre la implicación de la gerencia. Se encontró conveniente completar esta fase de estudio cuantitativa, ya que en la primera se puede ver que pasa a nivel interno, en profundidad y posteriormente en esta segunda fase se puede ver que pasa a nivel externo, a través del análisis cuantitativo. El análisis conjunto ofrece la visión amplia objetivo del estudio y permite contrastar la información real obtenida tras los estudios de caso, con la información obtenida a través del análisis cuantitativo y así poder tener más elementos de información que permitan caracterizar la proactividad medioambiental de la forma más completa posible.

\subsection{Primer estudio cuantitativo.}

Esta parte se realizó en tres pasos. En línea con Dubé y Paré (2003) los métodos de análisis estadísticos estándar como el análisis de varianza y el análisis de regresión ayudan a los investigadores a confirmar o rechazar hipótesis en investigación cuantitativa.

Los datos necesarios para la realización del estudio cuantitativo han sido tomados de la base de datos PITEC (Panel de innovación tecnológica). Se trata de una herramienta estadística que monitoriza las actividades tecnológicas y de innovación de las empresas españolas. Ha sido construida por el instituto nacional de estadística (INE) con el apoyo de académicos y expertos, e incluye empresas españolas caracterizadas por el tipo de innovación (según la clasificación del manual de Oslo, 2005), por industria (según la clasificación CNAE) 
o por localización geográfica. La versión tomada para el presente estudio es la correspondiente al año 2008, que recoge información de 11686 empresas, de las cuales 268 pertenecen al sector del automóvil.

El estudio se inició con un análisis factorial para reducir las variables de datos. Esta técnica permite encontrar las variables fundamentales que intervienen en la explicación de fenómenos, buscando las relaciones entre diferentes variables de datos, y permite obtener grupos homogéneos de variables correlacionadas. A continuación se realizó un modelo de regresión lineal y finalmente un análisis de correspondencias para medir el promedio de reciprocidad entre las variables estudiadas y la orientación medioambiental de la empresa. Los análisis se llevaron a cabo con el paquete estadístico SPSS para Windows.

Las variables tomadas para el estudio han sido seleccionadas según la teoría estudiada, de todas las variables disponibles se han elegido aquellas que tienen relación con el objetivo del estudio cuantitativo, son aquellas relacionadas con el tamaño de la empresa, con el mercado donde opera, con las inversiones en I + D y con las patentes de las empresas, son las siguientes: Ventas netas (NS) representa las ventas totales de la empresa en 2008; inversión en bienes total (INVER); tamaño de la empresa según número de empleados (SZ); mercado nacional, indica si la empresa opera en el mercado nacional (MDONAC); mercado europeo, indica si la empresa opera a nivel europeo (MDOUE); inversión total interna en I \& D (GINTID) ; inversión total externa en I \& D (GEXTD); número de empleados a tiempo completo en actividades de I \& D (PIDCA); número de patentes nacionales (PATNUM) y número de patentes europeas (PATEPO)

\subsection{Segundo estudio cuantitativo.}

La comprobación de la tercera hipótesis con un análisis cuantitativo suponía un reto mayor, ya que la implicación medioambiental de la gerencia no es una variable fácilmente medible y dicha información característica no era fácil de obtener. Se pensó entonces que la proactividad medioambiental estaba relacionada con el concepto de mejora continua, y con el concepto de innovación, cuando estas se aplican en relación con el medioambiente. Se optó por hacer una revisión bibliográfica buscando la relación entre dichos tres conceptos, y efectivamente se hallaron relaciones entre las tres, pero los estudios obtenidos relacionaban dichos conceptos de dos en dos, mejora continua con innovación, mejora continua con proactividad medioambiental y proactividad medioambiental con innovación. Y además no se 
habían encontrado estudios empíricos que relacionaran los tres conceptos a la vez entre sí, por lo que se optó por efectuar la exploración conjunta de los tres.

Para este estudio se han utilizado datos del Panel de Innovación Tecnológica PITEC (2009). La muestra está compuesta por 8038 empresas. Se han seleccionado las 32 variables que están relacionadas con mejora continua e innovación. La variable dependiente es la preocupación medioambiental al innovar (Denominada Objetivo 11 en PITEC). Se analiza la relación entre las variables a través del análisis factorial; a través de este análisis se buscan las relaciones que existen entre las diferentes variables de datos y se permite obtener grupos homogéneos de variables correlacionadas. A continuación se realiza un análisis de la varianza, (test ANOVA) para determinar si existen diferencias significativas entre cada una de los grupos obtenidos anteriormente. Por último se realiza un análisis discriminante para identificar las características que diferencian los grupos, permitiendo la determinación de grupos diferenciados. Posteriormente se comparan los grupos obtenidos en el análisis con la clasificación realizada según su proactividad medioambiental, de forma que si el grado de aciertos es lo suficientemente elevado se puede concluir que las funciones y por ello los factores que la componen están influyendo en esta clasificación y, por tanto, en la proactividad medioambiental.

\section{5.- Referencias.}

Cada artículo tiene al final su propia bibliografía, en este apartado se muestran todas las referencias bibliográficas utilizadas en el conjunto de los cinco artículos.

Abbaspour M., Karbassi A.R., Khadivi S., (2006), Implementation of green management concepts in sport complexes, International Journal of Environmental Research, 3, 213219.

ACEA, (2010), EU Economic report, European Automobile Manufacturers Association, Brussels, 193-199.

Aláez R., Bilbao J., Camino V., Longás J.C., (2009), Thoughts on the crisis in the Spanish automotive industry and its perspectives Spanish Business Information, ICE: Journal of Economics, Published in Spanish (Reflexiones sobre la crisis de la industria española del automóvil y sus perspectivas, Información Comercial Española, ICE: Revista de economía), 850, 41-56.

Albors, J. (2002), Pautas de innovación tecnológica industrial en una región intermedia. El caso de la Comunidad Valenciana, Economía Industrial, 346, 135-146.

Albors-Garrigós J, Hervás-Oliver JL (2006). La industria cerámica europea en el siglo XXI. Retos tecnológicos y desafíos de la próxima década. Boletín Sociedad Española. Cerámica.. V., 45, 1, 13-21.

Albors-Garrigós J, Marquez-Rodríguez P, Segarra-Oña, M. (2009) Internet como herramienta de creación de valor en sectores maduros. El caso de los productores y 
distribuidores cerámicos en España. Análisis empírico de los factores moderadores. Bol. Soc. Esp. Ceram. V. 48 (6):279-288

Albors-Garrigós, J., Hervás-Oliver, J. Segarra-Oña, M. (2009), Análisis de las prácticas de mejora continua en España barreras y facilitadores, Economía Industrial, 373, 185-195.

Álvarez Gil MJ, De Burgos Jiménez J, Céspedes Lorente JJ (2001). Un análisis exploratorio de las estrategias medioambientales y el contexto organizativo de los hoteles españoles, Cuadernos de Economía y Dirección de la Empresa, núm. 8, pp. 5-32.

Amadieu P, Viviani J P (2010). Intangible Effort and Performance: The Case of the French Wine industry. Agribusiness Vol. 26 (2) 280-306.

ANFAC, (2009), Memoria de 2008, Spanish vehicles Manufacters Association, Madrid.

Angell, L., Klassen, R. (1999), Integrating environmental issues into the mainstream: an agenda for research in operations management Journal of Operations Management 17, 575-598

Aragón-Correa J.A., (1998), Strategic proactivity and firm approach to the natural environment, Academy of Management Journal, 41, 556-568.

Aragón-Correa JA, Sharma S, (2003) A Contingent Resource-based view of proactive corporate environmental strategy. Academy of Management Review,Vol 28. No. I. 7188.

Aragón-Correa, J. A., Hurtado-Torres N, Sharma S, García-Morales V. (2008), Environmental strategy and performance in small firms: A resource-based perspective, Journal of Environmental Management, 86, 1, 88-103.

Arroyo Menéndez, M. (2009), "Diseño y validación de variables escalares en encuestas: comportamiento de Indicadores empíricos y la percepción de los entrevistados", http://eprints.ucm.es/5853/1/dise\%C3\%B1o_de_escalas.pdf, E-Prints-Complutense.

Azzone G, Bertele U, (1994). Exploiting Green Strategies for Competitive Advantage, Long Range Planning, Vol. 27, No. 6, pp. 69-81

Banerjee SB (2002) Corporate environmentalism, the construct and its measurement. Journal of Total Business Research Vol. 55, pp. 177-191.

Banerjee SB, Iyer SY, Kashyap RK (2003) Corporate environmentalism Antecedents and influence of industry type. Journal of Marketing Vol. 67, pp. 106-122.

Bansal, P., Roth, K., (2000), why companies go green: a model of ecological responsiveness. Academy of Management Journal, 43, 4, 717-736.

Bessant, J. (1998), Developing Continuous Improvement Capability. International Journal of Innovation Management, 2, 4, 409-429.

Bessant, J., Burnell, J., Harding R., Webb S., (1993), Continuous Improvement in British Manufacturing. Technovation, 13, 4, 241-254.

Bessant, J., Francis, D., (1999), Developing Strategic Continuous Improvement Capability, International Journal of Operations \& Production Management 19, 11, 1106-1119.

Beveridge W.I.B., (1951), The art of scientific investigation, William Heinemann, London.

Billiot MJ, Daughtrey ZW (2001) Evaluating Environmental Liability through Risk Premium Charged on Loans to Agribusiness Borrowers. Agribusiness, Vol. 17 (2), 273297.

Bond, T. C., (1999), The Role of Performance Measurement in Continuous Improvement. International Journal of Operations \& Production Management, 19, 12, 1318-1334.

Boyd G.A., McClelland J.D., (1999), The impact of environmental constraints on productivity improvement in integrated paper plants, Journal of Environmental Economics and Management, 38, 121-142.

Bravo Gil R, Fraj Andrés , Martínez Salas E. (2005). La importancia del factor medioambiental en las estrategias corporativa y de marketing: una aplicación al sector de bienes de consumo. Cuadernos de estudios empresariales, No 15, 199-224. 
Brunnermeier S.B., Cohen M.A., (2003), Determinants of environmental innovation in US manufacturing industries, Journal of Environmental Economics and Management, 45, 278-293.

Buil-Carrasco I, Fraj-Andrés E, Martínez-Salinas E, Matute-Vallejo J, (2005) Tipología de empresas medioambientales en el sector de bienes de consumo final. Revista de economía y empresa, $n^{\circ} 54$ y 55 , Vol. XXIII ( $2^{\mathrm{a}}$ época), $2^{\circ}$ y 3 er cuatrimestre, 69-93.

Burciu A., Bostan I., Condrea P., Grosu V., (2010), Financing the environmental policies in the Communitarian space, Environmental Engineering and Management Journal, 9, $1179-1185$.

Butler, J. (2008) The Compelling "Hard Case" for "Green" Hotel Development, Cornell Hospitality Quarterly, 49 (3), pp. 234-244.

Buysse K, Verbeke A, (2003) Proactive environmental strategies: A stakeholder management perspective. Strategic Management Journal, 24, 453-470

Carretero Peña AA (2009). Aplicación de la Norma UNEE 150008:2008 para la realización de Análisis de Riesgos Medioambientales en el contexto de la ley 26/2007 de Responsabilidad Medioambiental. Boletín Sociedad. Española. Ceramica. V., 48, 4, 7-8.

Christmann P (2000). Effects of 'best practices' of environmental management on cost advantage: The role of complementary assets. Academy of Management Journal, 43, 663-680.

Cilleruelo-Carrasco, E., Sánchez-Fuente, F., Etxebarría-Robledo, B. (2008), Compendio de definiciones del concepto innovación realizadas por autores relevantes: diseño híbrido actualizado del concepto. Dirección y Organización, 36, 61-68.

Clarkson PM, Li Y, Richardson GD, Vasvari FP, (2011):'Does it really pay to be green? Determinants and consequences of proactive environmental strategies. J. Account Public Policy 30, 122-144

Claver-Cortés E., López M.D., Molina J.F., Tarí J.J., (2007), Environmental management and firm performance: A case study, Journal of Environmental Management, 84, 606619.

Cordente-Rodríguez M., Mondéjar-Jiménez J.A., Meseguer-Santamaría. M., MondéjarJiménez J., Vargas-Vargas M., (2010), Environmental behavior and selective waste management in Spanish housing, Environmental Engineering and Management Journal, 9, 1165-1171.

Cox M.A., Cox T.F., (2008), Multidimensional scaling, In: Handbook of Data Visualization, Chen C.-h., Hardle W., Unwin A. (Eds), Springer Handbooks of Computational Statistics, Springer, 315-347.

Crotty M, Smith J, (2008) Environmental Regulation and Innovation Driving Ecological Design in the UK Automotive Industry Bus. Strat. Env. 17, 341-349 (2008) Published online 29 August 2006 in Wiley InterScience (www.interscience.wiley.com) DOI: 10.1002/bse. 550

D’Amico F., Buleandra M.M., Buleandra M., D’Amico G., Tanase J., (2010), Industrial district revitalization through sustainable development policies, Environmental Engineering and Management Journal, 9, 281- 291

Da Silva EM, Jabbour CJC, Santos FCA (2009). Integrating environmental management and manufacturing strategy: an emerging competitive priority. International Journal of Environmental Technology and Management. V.10, No 3, pp. $397-411$.

Damanpour, F. Gopalakrishnan, S., (2001), The dynamics of the adoption of product and process innovations in organizations. Journal of Management Studies, 38, 1, 45-65.

Darnall N, Henriques I, Sadorsky P, (2008) Do environmental management systems improve business performance in an international setting? Journal of International Management 14, 364-376 
Darnall, N., Henriques, I., Sadorsky, P., (2010), Adopting proactive environmental strategy: The influence of stakeholders and firm size. Journal of Management Studies, 47, 10721094.

Darnall, N., Jolley, G. J., Handfield, R. (2006), Environmental Management Systems and Green Supply Chain Management: Complements for Sustainability? Business Strategy and the Environment, 18, 30-45.

Davenport, T. H. (1993): Process Innovation. Boston, MA.: Harvard Business School Press.

De Benito-Valencia, C.M., (2000), La mejora continua en la gestión de calidad. Seis sigma, el camino para la excelencia, Economía Industrial, 331, 59-66.

De Ron, A., (1998), Sustainable production the ultimate result of a continuous improvement. International Journal of production economics, 56-57, 99-110.

Delmas M, Hoffmann VH, Kuss M (2011) Under the tip of the Iceberg: Absorptive Capacity, Environmental Strategy, and competitive Advantages Business and Society 50(I) 116-154

Dowell G, Hart S, Yeung B (2000). Do corporate global environmental standards create or destroy market value? Management Science, 46: 1059-1074.

Dubé L, Paré G (2003). Rigor in information systems positivist case research: current practices, trends, and recommendations. Mis Quarterly, Vol. 27, No 4, pp. 597-635

Esty, D. C., Winston, A. S., (2006), "Green to Gold, How smart companies use environmental strategy to innovate, create value, and build competitive advantage", John Wiley and Sons, Hokoben, New Jersey.

Faber A., Frenken K., (2009), Evolutionary methodologies for analyzing environmental innovations and the implications for environmental policy, Technological Forecasting and Social Change, 76, 462-470.

Fairchild R, (2008) The Manufacturing Sector's Environmental Motives: A Game-theoretic Analysis. Journal of Business Ethics, Vol. 79, No 3, pp. 333-334.

Ferguson M.E., Toktay L.B., (2006), The effect of competition on recovery strategies, Production and Operations Management, 15, 351-368.

Fernández-Olmos M, Rosell-Martínez J, Espitia-Escuer M (2009). Vertical Integration in the Wine Industry: A Transaction Costs Analysis on the Rioja DOCa. Agribusiness, Vol. 25 (2) 231-250 (2009)

Ferrari G., Mondéjar-Jiménez J., Vargas-Vargas M., (2010), Environmental sustainable management of small rural tourist enterprises, International Journal of Environmental Research, 4, 407-414

FIAB Federación española de industria de la alimentación y bebidas (2010) Economic report 2009. www.fiab.es/es/zonadescargas/industria.

Flyvbjerg B, (2006). Five Misunderstandings About Case-Study Research. Qualitative Inquiry. Vol. 12 No 2, pp. 219-245

Fritz M, Schiefer G (2008). Food Chain Management for Sustainable Food System Development: A European Research Agenda. Agribusiness, Vol. 24 (4), 440-452.

Fundación Entorno (2003). Entorno 2003. Informe sobre la gestión ambiental en la empresa española. Avances hacia la sostenibilidad. Madrid.

Gabaldon, S. Lopez, J. B. Carda, J. B. Legislación y gestiónmedioambiental en la producción de baldosascerámicas, Bol. Soc. Esp. Ceram. Vidr., 42 (3): 169-179, (2003).

Gadenne DL, Kennedy J, Mckeiver C, (2009) An empirical Study of environmental Awareness and Practices in SMEs. Journal of Business Ethics 84, 45-63

Galdeano-Gómez E, (2008) Does and Endogenous Relationship Exist between Environmental and Economic Performance? A Resource-Based view on the horticultural sector. Environ Resource Econ, 40:73-89 DOI 10.1007/s10640-007-9141-4

García F.J., Arma Y., (2007), Relation between social-environmental responsibility and performance in hotel firms, Hospitality Management, 26, 824-839. 
García-Sabater J, Marín-García J, 2009, Facilitadores y barreras para la sostenibilidad de la mejora continua: Un estudio cualitativo en proveedores del automóvil de la Comunidad Valenciana. Intangible Capital, 2009 - 5(2):183-209 - ISSN: $1697-9818$ doi: 10.3926/ic.2009.v5n2.p183-209

Gee, S. (1981). Technology transfer, innovation \& international competitiveness. Wiley and Sons, New York.

Gertsen, F. (2001): «How continuous improvement evolves as companies gain experience», nternational Journal of TechnologyManagement, Vol. 22, No. 4, pp.303-326.

González Benito J, González Benito O., (2005). Environmental proactivity and business performance: an empirical analysis. Omega International. Journal of Management Science, Vol. 33. No 1, pp.1-15.

González-Benito J, González-Benito O, (2006), A Review of Determinant factors of Environmental Proactivity. Business Strategy and the Environment 15, 87-102 (2006)

González-Benito J, González-Benito O, 2008, A Study of Determinant Factors of Stakeholder Environmental Pressure Perceived by Industrial Companies. Business Strategy and the Environment 19, 164-181.

González-Benito J, González-Benito O, (2010), A Study of Determinant Factors of Stake Environmental pressure perceived by industrial companies. Business Strategy and the Environment 19, 164-181

González-Torre P., Álvarez M., Sarkis J., Adenso-Díaz B., (2009), Barriers to the implementation of environmentally oriented reverse logistics: Evidence from the automotive industry sector, British Journal of Management, 21, 889-904.

Greenacre M.J., (1984), Theory and Applications of Correspondence Analysis, Academic Press, London.

Greenacre M.J., (1993), Correspondence Analysis in Practice. Academic Press, London.

Gruia R., Tane N., Marculescu A., Padureanu V., (2010), Study on the process of emergetic sustainability applied in the management of "environmental-economy" complex systems, Environmental Engineering and Management Journal, 9, 1647-1650.

Gupta M, 1994, Environmental management and its impact on the operations function. International Journal of Operations \& Production Management, Vol. 15 No. 8, 1995, pp. 34-51

Haddock-Fraser JE, Tourelle M, (2010) Corporate Motivations for Environmental Sustainable Development: Exploring the role of consumers in stakeholder engagement. Business Strategy and the Environment 19, 527-542

Hair, J.F., Anderson, R. E., Tatham, R. L., Black, W. C., (1998), Multivariate data analysis: with readings, 5th Ed. Englewood Cliffs, NJ: Prentice-Hall.

Hart, S.L., 1995. A natural-resource-based view of the firm. Academy of Management Review 20, 4., 996-1014.

Herea V., (2010), Policy and strategy for improving sustainable social development programmes. Environmental Engineering and Management Journal, 9, 861-868.

Hervás-Oliver, J. L Albors-Garrigós J (2009) The role of the firm's internal and relational capabilities in clusters: when distance and embeddedness are not enough to explain innovation. Journal of Economic Geography 9 (2009) pp. 263-283

Hitchens, D., Thankappan, S., Trainor, M., Clausen, J. \& De Marchi, B. (2005). Environmental performance, competitiveness and management of small businesses in Europe. Royal Dutch Geographical society, KNAG. Vol. 96, No. 5, pp. 541-557.

Hopwood B., Mellor M., O`Brien G., (2005), Sustainable development: mapping different approaches, Sustainable Development, 13, 38-52.

Huberty C.J., 1984 Issues in the use and interpretation of discriminant analysis. Psychological Bulletin, 95 (1984), pp. 156-171.

Hunt CB, Auster ER, (1990). Proactive environmental management: avoiding the toxic trap, Sloan Management Review 31 (2), pp. 7-18. 
Ingenleek P, Meulenberg MTG (2006). The Battle between Good and Better: A strategic Marketing Perspective on Codes of Conduct for Sustainable Agriculture. Agribusiness, Vol. 22 (4), 451-473.

IVEX, InstitutoValenciano de exportación, 2011.Información sectorial. http://www.ivex.es/dms/estudios/informacion_sectorial_CV/ceramicofeb/CERAMICOCV2011.pdf

Johnson, R.A., Wichern, D. W. (2001), Applied Multivariate Statistical Analysis. 5th Edition, prentice-hall, New Jersey.

Kalantari K, Asadi A (2010) Designing a structural model for explaining environmental attitude and behavior of urban residents (Case of Tehran). Int. J. Environ. Res., 4 (2), pp. 309-320.

Kaplan, R S (1986) The role for empirical research in management accounting. Accounting, Organizations and Society.

King A.A, Lenox MJ (2001) Does It Really Pay to Be Green? An Empirical Study of Firm Environmental and Financial Performance Journal of Industrial Ecology Volume 5, Number 1 105-116

King N (1994) "The qualitative research interview”, pp. 14-36. En Qualitative methods in organizational research, Cassel, C. y Simon G. Eds. Sage Publications, Ltd. London.

Kline S.J, Rosenberg N, (1986), The positive Sum Strategy: Harnessing technology for Economic Growth . National Academy Press. Washington. D. C.

Lawrence PR, Lorsch JW (1967) Organization and Environment Managing Differentiation and Integration. Boston, MA: Harvard University.

Liu X, Liu B, Shishime T, Yu Q, Bi J, Fujitsuka T (2010) An empirical study on the driving mechanism of proactive corporate environmental management in China. Journal of Environmental Management. Journal of Environmental Management, Vol 91, pp. $1707-1717$

López-Gamero MD, Claver-Cortes E, Molina-Azorín JF (2008): Complementary Resources and Capabilities for an Ethical and Environmental Management: A Qual/Quan Study. Journal of Business Ethics(2008) 82:701-732 DOI 10.1007/s10551-007-9587-x.

Marín-García, J. A.; Pardo del Val, M.; Bonavía Martín, T. (2008). La mejora continua como innovación incremental. El caso de una empresa industrial española. Economía Industrial $n^{\circ} .368$, pp. 155-169

Martín-Castilla J.I. (2007) La consideración de aspectos sostenibles en los enfoques de excelencia. Boletín económico de ICE n 2909.

Martín-Tapia I, Aragón-Correa J, Rueda-Manzanares A, (2010) Environmental Strategy and exports in medium, small and micro-enterprises. Journal of World Business 45, 266-275

McKeiver C, Gadenne D, (2005) Environmental management systems in small and medium businesses, International Small Business Journal, V. 23, n 5, 513-537.

Melnyk SA, Sroufe RP, Calantone R, (2003). Assessing the impact of environmental management systems on corporate and environmental performance. Journal of Operations Management. Vol. 21, No 3, 329-351.

Mezquita A, Monfort E, Zaera V (2009) Sector azulejero y comercio de emisiones: reducción de emisiones de CO2, benchmarking europeo. Bol. Soc. Esp. Ceram. V., 48, 4, 211-222.

Michaels S, Furuseth OJ (1997). Innovation in environmental policy: the National Environmental Policy Act of the US and the Resource Management Act of New Zealand. The Environmentalist 17, 181-190.

Miret-Pastor, L., Segarra-Oña, M., Peiró-Signes, A. (2011), Identification of service sectors and high technology in Valencia: a new cluster mapping? (In Spanish: Identificación de sectores de servicios y de alta tecnología en la Comunidad Valenciana: ¿Un nuevo cluster mapping?). Revista de estudios regionales, 90: 71-96. 
Mitchell R, Com M A, Wooliscroft B, Higham J (2010) Sustainable Market Orientation: A New Approach to Managing Marketing Strategy. Journal of Macromarketing, doi:10.1177/0276146710361928.

Molina-Azorín J.F., Claver-Cortés E., Pereira-Moliner J., Tarí J.J., (2009), Environmental practices and firm performance: an empirical analysis in the Spanish hotel industry, Journal of Cleaner Production, 17, 516-524.

Morrison, 1969 D.G. Morrison, On the interpretation of discriminant analysis. Journal of Marketing Research, 62 (1969), pp. 156-163.

Morrow D, Rondinelli D, 2002, Adopting Corporate Environmental Management Systems: Motivations and Results of ISO 14001 and EMAS Certification. European Management Journal Vol. 20, No. 2, pp. 159-171, 2002

Murillo, Garcés, Rivera (2004) Estrategia empresarial y medio ambiente: opinión de un grupo de expertos, Universia Business Review- Actualidad económica, cuarto trimestre, $52-63$

Murillo-Luna J, Garcés-Ayerbe C, Rivera-Torres P, (2008) Why do patterns of environmental response differ? A stakeholders' pressure approach. Strategic Management Journal 29: 1225-1240

Noci G, Verganti R, (1999) 'Managing Green' product innovation in small firms. R\&D Management 29, 1

Orsato RJ, (2006) Competitive environmental strategies: when does it pay to be green? California Management Review Vol. 48, No.2

Oslo Manual, (2005) Guidelines for collecting and interpreting innovation data. Third edition, OECD and Eurostat organization for economic co-operation and development statistical office of the European Communities.

Papadopoulos, T (2011) "Continuous improvement and dynamic actor associations: A study of lean thinking implementation in the UK National Health Service", Leadership in Health Services, Vol. 24 Iss: 3, pp.207 - 227.

Paulraj A., (2011), Understanding the relationships between internal resources and capabilities, sustainable supply management and organizational sustainability, Journal of Supply Chain Management, 47, 19-37.

Peiró-Signes A, Segarra-Oña M, Miret-Pastor L, Verma L. (2011) An important key for promoting efficient vertical policies. Environmental Engineering and Management Journal, 10 (12), 1893-1901.

Peiró-Signes, A., Segarra-Oña, M., Miret-Pastor, L., Verma, R. (2011) Eco-innovation attitude and industry's tecnological level. An important key for promoting efficient vertical policies. Environmental Engineering and Management Journal.10 (12): 18931901.

Penrose E.T., (1959), The growth theory of the firm, Wiley, New York.

Perreault, W. D., Behrman, D. N., Armstrong, G.M, (1979), Alternative approaches for interpretation of multiple discriminant analysis in marketing research. Journal of Business Research, 7, 151-173.

Perrin, B. (1995), Evaluation and future directions for the Job Accommodation Network (JAN) in Canada. Final Report.Employment Policies and Operations, HRDC.

Peteraf M (1993) The cornerstone of competitive advantage: a resource based view, Strategic Management Journal, Vol. 14, pp. 179-191.

Pianta, M (2003). Innovation and employment, in: I. Faberberg, D. Mowery and R.R. Nelson (Eds), Handbook of Innovation. Oxford University Press (forth) Chapter 22.

Porter M.E., Van der Linde C., (1995), Toward a new conception of the environment competitiveness relationship, Journal of Economic Perspectives, 9, 97-118.

Ratnasingam J, Wagner K (2010) The Impact of ISO 14001 on the Operations Management of Wooden Furniture Manufactureres in Malaysia. Eur. J. Wood Prod. 68:479-481 DOI 10.1007/s00107-009-0370-9. 
Repetto R., Rothman D., Faeth P., Austin D., (1997), Has environmental protection really reduced productivity growth, Challenge, $41,46-57$.

Rivas J, Magadán M (2010) Less green taxes and more control over pollutant industries: a theoretical proposal Environmental Engineering and Management Journal, 9 (9) 11731177

Rondinelli D, Vastag G (2000) Panacea, common sense or just a label? The value of ISO 14001 Environmental management systems.European Management Journal Vol. 18, No. 5, pp. 499-510, 2000

Roome N (1994) Business strategy, R\&D management and environmental imperatives, R\&D Management 24, Vol. 1, pp. 65-82

Rouse M J, Daellenbach U S (1999) Rethinking research methods for the resource-based perspective: isolating sources of sustainable competitive advantage. Strategic Management Journal 20:487-494.

Russo MV, Harrison NS (2005) Organizational design and environmental performance: clues from the electronics industry. Academy of Management Journal, V. 48, No 4, pp. 582-593.

Schaefer A, Harvey B, (1998) Stage models of corporate 'greening': a critical evaluation. Business Strategy and the Environment 7(3), 109-123.

Schumpeter, J.A. (1939). Business cycles: a theoretical, historical and statistical analysis of the capitalist process. McGraw-Hill, Nueva York.

Segarra-Oña, M., De Miguel Molina, B. (2009), Evaluación de la Concentración Industrial Sinérgica: propuesta metodológica y aplicación a un sector industrial, TEC Empresarial 65, 3 (1-2): 65-72.

Segarra-Oña M, Segura B, Martínez M (2009) La integración de la proactividad medioambiental en la estrategia empresarial: un estudio empírico. XI Reunión de Economía mundial. Congress proc. (I.S.B.N.: 1887-9489)

Segarra-Oña M, Carrascosa-López C, Segura-García-del-Río B, Peiró-Signes A (2011a) Empirical analysis of the integration of environmental proactivity into managerial strategy. Identification of benefits, difficulties and facilitators at the Spanish automotive industry, Environmental Engineering and Management Journal, Forthcoming.

Segarra-Oña, M., Peiró-Signes, A., Albors-Garrigós, J., Miret-Pastor, P.,(2011b) Impact of Innovative Practices in Environmentally Focused Firms: Moderating Factors, Int.J.Environ.Res, 5 425-434.

Segarra-Oña M., Carrascosa-López C., Segura B., (2011c), Do companies know which are the barriers and facilitators that enable proactive environmental orientation of the industry? An empirical study of a low tech industry, Information Technologies in Environmental Engineering Environmental Science and Engineering, 3, 373-388.

Segarra-Oña, M. Peiró-Signes, A., Miret-Pastor, L.,Albors-Garrigós, J. (2011d) ¿Ecoinnovación, una evolución de la innovación? Análisis empírico en la industria cerámica española Bol. Soc. Esp. Ceram. V. 50(5):253-260.

Sharma S, Aragón-Correa JA Rueda-Manzanares A (2007) The contingent influence of organizational capabilities on proactive environmental strategy in the service sector: an analysis of North American and European ski resorts. Canada Journal of Administrative Sciences, V. 24, pp. 268-283.

Sharma S, Vredenburg H (1998) Proactive corporate environmental strategy and the development of competitively valuable organisational capabilities. Strategic Management Journal Vol. 19, pp. 729-753.

Shrivastava, P. (1995): "The role of corporations in achieving ecological sustainability", Academy of Management Review, 20, 4, 936-60.

Simpson D., Power D., Samson D., (2007), Greening the automotive supply chain: a relationship perspective, International Journal of Operations and Product Management, 27, 28-48. 
Singh RK, Murty HR, Gupta SK, Dikshit AK (2008) Development and implementation of environmental strategies for steel industry, Int. J. Environmental Technology and Management, Vol. 8, No. 1, pp. 69-86.

Smith AD (2010) Growth of corporate social responsibility as a sustainable business strategy in difficult financial times. International Journal of Sustainable Economy Vol. 2, No 1 , pp.59-79

Stake RE (1995) The art of case study research. Thousand Oaks, CA. Sage.

Telle K, Larsson J (2007). Do environmental regulations hamper productivity growth? How accounting for improvements of plants' environmental performance can change the conclusion. Ecological Economics, Vol. 61, pp. 438-445.

Trott P, (2008), Innovation management and new product development. 4th edition. Pearson Education Limited. ISBN 978-0-273-71315-9

Vargas-Vargas M, Meseguer-Santamaría ML, Mondéjar-Jiménez J, Mondéjar-Jiménez JA, (2010) Environmental Protection Expenditure for Companies: A Spanish Regional Analysis, International Journal of Environmental Research, 4 (3) 373-378.

Vastag G, Kerekes S Rondinelli DA (1996) Evaluation of corporate environmental management approaches: A framework and application. International Journal of Production Economics.V. 43, No 2-3, pp. 193-211.

Vega-Jurado, J., Gutiérrez-Gracia, A., Fernández-de-Lucio, I. (2009), 1LLa relación entre las estrategias de innovación: coexistencia o complementariedad Journal of Technology Management \& Innovation, 4, 3, 74-88.

Verbeke A, Bowen F, Sellers M (2006). Corporate environmental strategy: extending the natural resource-based view of the firm. Acad of Management Best Paper

Villavicencio, J. M. (2007) Factoresqueinciden en el desempeñoexportador de lasPymes: unaaplicación empírica, Tec Empresarial, 1(4) 28-40

Vyas S., Kumaranayake L., (2006), Constructing socio-economic status indices: how to use principal components analysis, Health Policy and Planning, 21, 459-468.

Walker H, Di Sisto L, McBain D (2008). Drivers and barriers to environmental supply chain management practices: lessons from the public and private sectors. J. of Purchasing \& Supply Management, Vol. 14, pp. 69-85.

Welford R., (1995), Environmental Strategy and Sustainable Development, Routledge, London.

Wijnands JHM, Bremmers HJ, Van der Meulen BMJ, Poppe KJ (2008) An Economic and Legal Assessment of the EU Food Industry's Competitiveness. Agribusiness, Vol. 24 (4), 417-439

Winsemius P, Guntram U (1992) Responding to the environmental challenge, Business Horizons 35 (2), pp. 12-20.

Zhu Q., Sarkis J., Lai K., (2007), Green supply chain management: pressures, practices and performance within the Chinese automobile industry, Journal of Cleaner Production, 15, 1041-1052. 


\section{CAPítulo 2}

DO COMPANIES KNOW WHICH ARE THE BARRIERS AND FACILITATORS THAT ENABLE PROACTIVE ENVIRONMENTAL ORIENTATION OF THE INDUSTRY? AN EMPIRICAL STUDY OF A LOW TECH INDUSTRY. 


\title{
Do companies know which are the barriers and facilitators that enable proactive environmental orientation of the industry? An empirical study of a low tech industry.
}

\author{
Conrado Carrascosa- López ${ }^{1}$, Marival Segarra-Oña ${ }^{1}$, Baldomero Segura-García-del- \\ Río $^{2}$
}

\author{
${ }^{1}$ Departamento de Organización de Empresas, Universidad Politécnica de Valencia. Camino de Vera s/n 46022 Valencia \\ concarlo@upvnet.upv.es \\ maseo@omp.upv.es \\ ${ }^{2}$ Departamento de Economía y Ciencias Sociales, Universidad Politécnica de Valencia. Camino de Vera s/n 46022 \\ Valencia \\ bsegura@upvnet.upv.es
}

\begin{abstract}
A growing number of companies consider aspects tied to sustainable development, environmental attitude, eco-innovation or environmental management to be a first-class asset on a strategic level. In this context, management of sustainable development becomes a crucial process.

The aim of this work is to analyze the real incorporation of environmental proactivity into company's global strategy as a value generating element. The methodology used is case study analysis, with personal interviews to people in charge of the environmental management department that answer an environmental proactivity survey. The empirical application focuses on a low-tech industry, the Spanish food sector. The objective of the research is to identify which aspects determine company's environmental strategy, which are the barriers and facilitators that enable proactive environmental orientation of the industry studied and to verify what benefits companies can obtain from its application.
\end{abstract}

Keywords: Environmental proactivity, Sustainable development, Strategy, Management, Food industry, Low tech industry.

\section{Introduction}

Traditionally the industrial sector has been considered as the most directly responsible for environmental degradation, although this impact has been declining in recent years thanks to rising environmental concerns and the implementation of laws and regulations by governments to control pollution (Fairchild 2008). These changes have led to the implementation in companies of different environmental strategies, since environmental response to environmental proactivity (González-Benito and González-Benito 2006).

Nowadays, environmental care is often considered in the business strategy of companies (Singh et al. 2008). Establish how to incorporate environmental orientation in business is a competitive priority to be taken into account in the manufacturing strategy (Da Silva et al. 2009). Environmental proactivity offers a vision that integrates medium and long term 
objectives. Local, global, social and economic actions are integrated as well. Economic issues and the environment are interdependent and inseparable components in human progress (Porter and Van der Linde 1995).

An increasing number of companies consider issues related to sustainable development, environmental attitude, eco-innovation or environmental management as a first class asset at the strategic level. (Dowell et al. 2000, Christmann 2000, Noci and Verganti 1999). In this context, sustainable development management becomes a necessary process.

The need for companies to differentiate through sustainability is growing in importance, but there is still no scientific basis for measuring. Because of this, it is necessary to analyze the environmental factor as a proactive aspect of business management, as well as factors that motivate companies to move towards environmental protection in what is called corporate environmental science. (Banerjee 2002, Banerjee et al. 2003). Several authors have analyzed integration of environmental factor in business (Hitchens et al. 2005). In general, the influence of factors such as social pressure (Kalantari and Asadi 2010), environmental legislation (Telle and Larsson 2007), competitive advantages (Albors-Garrigós and Hervas-Oliver 2006, Segarra-Oña et al. 2011) and management commitment to the company's environmental focus (Russo \& Harrison 2005) and also studied aspects of their strategies (Walker et al. 2008, Bravo el al. 2005, Liu et al. 2010) or its adaptation to the rules (Mezquita et al. 2009, Carretero Peña, 2009). 


\section{Research approach}

\subsection{Objectives and paper structure}

Several authors have studied how environmental management tools affect business competitiveness; Russo and Harrison (2005) pointed out that incentives were a valuable tool to improve environmental performance and, therefore, the promotion of environmental performance could be an opportunity to shape the redesign of an organization to be more proactive. McKeiver \& Gadenne (2005) analyzed both external and internal factors that influence the implementation of an environmental management system. Other authors studied how competitive advantage could be gained through environmentally-oriented activities (Sharma and Vredenburg, 1998) or how business performance can be improved taking into account environmental concerns (González Benito and González Benito 2005, Melnyk et al. 2003).

Several studies have studied the empirical level of environmental proactivity in the industry. In Spain, Aragón-Correa et al (2008) observed that in the automotive repair industry, companies with proactive practices got better economic performance. In the work done by Martin-Tapia et al (2009) the food sector was studied, and evidence was found of the correlation between environmental strategies and advanced level of exports.

It is a need, at this time of economic difficulties, because environmental liability can be a source of financial risk (Billiot and Dauhtrey 2001), to analyze the inclusion of environmental proactivity in the overall strategy of organizations as a differentiator, creator of competitive advantage, analyzing the degree of inclusion of environmental factor as part of business strategy.

Considering the above, the main objective of this research is to analyze environmental proactivity as an aspect of business management and to identify factors that help companies to move towards sustainable management; The specific objectives are to identify factors that characterize environmental performance and the identification of facilitators and constraints encountered by companies regarding their environmental management (Walker et al. 2008).

This study has been developed in the Spanish food sector, analyzing company's business operations in order to identify potential improvement actions.

This research verifies the existing literature on environmental proactivity, environmental strategy and environmental determinants in the industry, to identify the most representative factors affecting the decisions of companies in the food sector. The study sample consists of 18 heterogeneous firms, all of which have in common the membership to the food and beverage sector.

A survey has been developed to measure environmental integration (Segarra et al. 2009), used as a tool to guide the interviews, through a case study that contributes to the development and accumulation of knowledge (Flyvbjerg 2006, Stake 1995). The results of the interviews with responsible persons of the environment department have been analyzed; they have been grouped according to the type of company (national, multinational, size). The results help explain the differences between the companies, all in the same industry. After analysis and discussion of the results obtained, the paper concludes with the presentation of its findings.

The structure of this paper is as follows. First we review the existing literature on environmental strategy, applied to the case study of the Spanish food sector, adding a current view of the situation of that sector. The following step is to show the methodology applied, and the analysis of the results: the identification of facilitators, barriers and benefits of environmental proactivity. Finally the work ends with a discussion of the results and conclusions 


\subsection{Review of literature on environmental strategy}

There have been made different classifications in accordance to the environmental strategy, however, in general, there have been defined four groups in terms of exogenous and endogenous environmental risks: preventive, strategic, proactive and reactive.(Winsemius and Guntram 1990, Vastag et al. 1996, Fundación entorno 2003). In order to identify the factors taken into account for classification purposes, the Spanish Fundación Entorno (2003), classifies the companies as leaders, those who recognize in the environment opportunities for innovation and improvement; enthusiasts, those with implemented environmental management systems; proactive, those that integrate environmental considerations into their operations and are prepared to take advantage of opportunities offered by the environment; reactive, those that react to environmental obligations, and make decisions strictly to comply with environmental legislation; and indifferent; those that see difficulties in taking the necessary measures and are not involved and even see environmental concerns as a threat to its operations and its existence.

There are different classifications in response to different criteria. According to Hunt and Auster (1990): in beginner, fighter, concerned citizen, pragmatist or proactive. Winsemius and Guntram (1992): as reactive, receptive or proactive. Roome (1994): as non compliance, compliance, compliance plus, excellent and leading edge. Azzone and Bertelé (1994): as stable, reactive, anticipatory, proactive or creative. Vastag et al. (1996): as reactive, crisis preventive, strategic or proactive. Schaefer and Harvey (1998): as beginner, fighter, concerned, pragmatic or proactive and according to González-Benito and González-Benito (2005) as reactive, pro-certification, pro-design, pro-logistics or pro-commercial.

It has also been considered the combination of the resource-based view, RBV (Peteraf 1993) with the development of a theoretical framework to analyze the relationship between environmental strategies and development of specific environmental responsibilities (Verbeke et al. 2006, Sharma 2007, Da Silva et al. 2009, Smith 2010).

Although they may look different, they all have in common that they analyze the strategic position in various intermediate stages between the more reactive and more proactive point of view (Alvarez et al. 2001).

Moreover, the determinants of proactive environmental orientation are classified as internal aspects of the company (size, level of internationalization, position in value chain, management attitude, motivation and strategic approach of the companies as well) externalities (sector and geographic location) and as a determining factor, the involvement of owners and shareholders (Gonzalez-Benito and Gonzalez-Benito 2006). Also Murillo et al. (2004) classify factors as external (legislation, customers, vendors, companies in the sector, financial institutions, insurance, media, environmental and / or citizens or nearby communities) and internal (management, partners and shareholders and / or employees). Managers' commitment to contribute to sustainable development may be a source of competitive advantage (Lopez-Gamero et al. 2008)

Some studies have been developed trying to identify factors that affect the environmental orientation adopted by companies. In the consumer goods sector, factors such as the influence of external pressures, environmental orientation, marketing and corporate strategies, company size, sector size, and whether or not the company has a marketing department, have influence on the environmental strategy adopted (Buil-Carrasco et al. 2005, Mitchell et al. 2010). González-Benito and González-Benito (2006) identified various proactive environmental strategies in three industrial sectors, electricity, chemicals and furniture, noting the multidisciplinary nature of environmental proactivity. 
The hypothesis of this research are then raised

H1: Small size is a barrier to a company's environmental proactivity. H2: Multinational nature of a company facilitates its proactive environmental orientation. H3: Direct involvement of management is essential to facilitate proactive orientation.

\subsection{Methodology}

Following Kaplan (1986), it is difficult to imagine that theories can be verified in the field of business management if the study is not made within the organizational context. According to Rouse and Daellenbach (1999) in-depth case studies provide valuable field data to point out factors that influence management. There have been written several case studies focused in the sustainable agriculture in Netherlands (Ingenleek and Meulenberg 2006), in the French wine industry, (Amadieu and Viviani 2010), therefore it is interesting to study the food sector in Spain in a case study.

The method used in this study, interviews, is classified as direct collection of information (Stake, 1995). The type of interview used is called a structured open-ended interview (King, 1994). This technique combines the advantages of closed questionnaires with qualitative research open questionnaires. According to Dubé and Paré (2003) case studies require some recommendations for achieving a high level of rigor in research. These recommendations have been followed in this study and are the following: Firstly, considering aspects related with the design, identifying research questions, secondly aspects of data collection itself, procedural aspects, such as the number of interviews, interviewed, using an interview guide, etc.., effective use of tables to summarize information about the process of data collection or how to triangulate data to increase the internal validation of the results and clear explanations of the process. And finally with data analysis procedures, in order to provide clear descriptions of the analytic methods and procedures techniques to compare the results with existing literature.

A questionnaire Likert scaled was prepared, with five possible answers and an additional alternative response that indicates that there is insufficient information to answer. The questionnaire has been filled in person by the authors of the study, in order to characterize the company and their level of environmental proactivity and thus establishing a system to measure integration of environmental proactivity on business strategy.

On the other hand, the interview is conducted personally by one of the researchers, in order to collect all possible qualitative information. Through informal talks with employees, you can see different aspects of products, processes, and know how of the company. (Stake 1995)

The questionnaire consists of a total of 42 questions designed to identify aspects that characterize the company in terms of environmental proactivity, organizational aspects as well, establishing a system to measure integration of environmental proactivity into company's business strategy

Before use, the questionnaire was submitted to a test to see and discuss the suitability of the questions. The interviews were conducted to company managers personally to obtain more reliable results.

\section{Practical application to the Spanish food sector}

This practical application is based on the Spanish food sector. This sector is one of the three pillars of the Spanish industry, together with automobile and chemical industry. A brief description of this sector is shown, based on the information obtained from the FIAB, Spanish federation of food and beverage industry, (2010). The food and beverage industry had in Spain in 2009, 30650 companies. Among these, 99, $2 \%$ are considered SME's (Small and medium enterprises) and only $0,8 \%$ Big companies. This sector employs $17 \%$ of the total jobs on the industry. The Spanish sector of the food industry had 84,600 million Euros net 
sales in 2009; this represents $14 \%$ of the industry's net sales and $8.04 \%$ of Spanish GDP. In terms of foreign trade, the export value accounted in 200915053 million euros, compared to a value of imports of 14.787 million euros. This represented a positive trade balance in 2009 of 266 million euros. This sector helps to level the foreign trade balance in Spain. This sector has a higher rate of innovative companies than in the rest of the Spanish economy.

It is worth the deep study of this sector, because it is considered that adopting environmentfriendly practices has a greater influence in it than in manufacturing sectors (Galdeano-Gómez 2008). Few empirical studies have been conducted in the agriculture and food and beverage industry (Fernández-Olmos et al. 2009). There is high interest in formulating priority challenges for managerial improvements to increase sustainability of the food sector (Fritz and Schiefer 2008)

\section{Results analysis}

The sample studied is composed of 18 heterogeneous companies, all of them belonging to the FIAB (Spanish federation of food industry and beverage). The sample is mixed, 38\% are big companies and 62\% are SME's (Small and medium enterprises). Among these companies, $72 \%$ are only Spanish companies, and $28 \%$ are multinational.

In terms of environmental department it's important to mention that $55 \%$ of the companies of the sample have own environmental department. The same amounts of companies (55\%) have environmental accreditation already gained or are in process of obtaining it. It is interesting to disaggregate this data according to the size of the companies, because $71 \%$ of the big companies have the accreditation or are in process to gain it, while only $45 \%$ of SME's (Small and medium enterprises) are in the same situation. If the info is disaggregated according to the national or multinational characteristic of the companies, the result is the following: $60 \%$ of the multinational companies have the accreditation or are in process to gain it, while only $53 \%$ of national companies are in the same situation.

According to the first of the hypotheses based on the study of literature, the larger companies are a larger percentage of environmental proactivity they should have. According to the second hypothesis, multinational companies should provide a better percentage of environmental proactivity than national ones.

According to the third hypothesis; companies with management directly involvement in environmental matters should provide a higher percentage of environmental proactivity.

In the last section of this paper these hypotheses are contrasted with the reality of the companies studied

\subsection{Facilitators identification}

Facilitators of environmental proactivity are defined as those factors that help and lead the company to be more proactive. Their identification is one of the objectives of this study; it was carried out by analyzing the results of surveys to each of the companies, first recognizing those companies with better environmental performance, and then relating what characteristics have helped these companies achieve this best performance.

According to González-Benito (2006), facilitators of corporate environmental proactivity may be internal or external. This study focuses on the internal ones; the analysis of the survey shows three: the size of the company, its degree of internationalization and management involvement with the environment. From the analysis of those questions used to characterize the environmental performance is obtained a percentage that indicates the environmental performance of the companies.

The groups considered come from the breakdown of each of the facilitators, and companies are grouped in three different ways: firstly by size: SME's (Small and medium enterprises) and big companies, secondly according to their degree of internationalization in national and 
multinational, and finally according to the environmental implication of management: high or low

In the following table (see table 4.1), the environmental performance of companies is characterized after taking into account the grouping with the before mentioned facilitators.

At the horizontal level are represented actions that characterize the environmental performance and the columns are clusters of companies according to the above-mentioned facilitators, in that way that a high percentage indicates that the group required can be considered as environmentally proactive.

Table 4.1 Facilitators identification

The aggregation of the surveys and the grouping of companies according to different facilitators, enable to see the influence of each of them on the behaviors that characterize environmental proactivity, which are detailed in the left column.

\subsection{Obstacles identification for environmental proactivity}

The biggest obstacles companies face when trying to adopt a more proactive environmental strategy, as obtained from the analysis of surveys, and in aggregated value of the total sample, are the following, the higher percentage, the biggest importance is given by companies to that obstacle.

- Short financial support $(72,22 \%)$.

- Lack of institutional support $(64,44 \%)$

- Lack of tools information $(54,44 \%)$

- Lack of technical solutions $(51,11 \%)$

- Lack of qualified human resources $(46,67 \%)$.

The following table describes the obstacles to environmental proactivity, as the perception of companies, grouped taking into account the above-mentioned facilitators

Table 4.2 Obstacles for environmental proactivity

Again, the aggregation of the surveys and the grouping of companies according to the different facilitators enable to see the influence of each and the relationship of each with the obstacles noted in the left. This detailed information indicates what are the difficulties encountered by each one of the groups, and could be considered the basis to suggest potential actions for improvement.

\subsection{Benefits identification for environmental proactivity}

Companies identify potential benefits resulting from the implementation of actions from proactive environmental management. These are listed below in order of importance; the higher percentage indicates the importance given by companies to that benefit:

- Avoid sanctions $(85,56 \%)$.

- Improvement of corporate image $(78,89 \%)$

- Long term cost savings $(77,78 \%)$

- Long term economic benefits $(74,44 \%)$.

The breakdown in the table below shows the benefits seen by companies according to the grouping considered.

Table 4.3 Benefits of environmental proactivity.

The aggregation of the Surveys and the grouping of results by the different facilitators, allow to see the influence of each and the relationship with each of the benefits seen in the left column. 
This information is very revealing, because although the social level of environmental awareness is a factor that is present in society, its practical application, its potential economic benefits, its contribution to the improvement of competitiveness of the company that applies it (Da Silva et al. 2009), its vision that integrates short-, medium and long term objectives (Porter and Van der Linde 1995) is not as present in the corporate culture

\section{Results discussion and conclusions}

\subsection{Model developed and verification of hypotheses}

Environmental proactivity of a low-technology industry has been studied; specifically the Spanish food sector, and the barriers and facilitators considered important for the inclusion of environmental proactivity on business strategies have been identified by companies. Figure 1 shows the model developed by the authors based on field work.

Figure 5.1 Environmental management model food sector companies.

With respect to the hypotheses in our study,

H1: Small size is a barrier to a company's environmental proactivity. With the information obtained after the surveys analysis, this hypothesis is not verified. Although in table 1 , is observed that in average, big enterprises have a better environmental performance than Small and medium enterprises, it's interesting to mention that there is one exception. There's one small company with better environmental behavior than big companies. This company is multinational and its management is highly implicated in environmental management. This demonstrates that facilitators multinational nature and management involvement seem to be more decisive for companies to have a good level of environmental proactivity. Clearly, the study is based on Spanish food sector companies, and is for these companies for which we can conclude that small size is no barrier. It is also verified that big size of companies acts as a facilitator of environmental proactivity

H2: Multinational nature of a company facilitates its proactive environmental orientation. This hypothesis is fulfilled because multinational companies have better environmental behavior than national ones.

H3: Direct involvement of management is essential to facilitate proactive orientation. This hypothesis is verified because companies with high implication of management have better environmental behavior than the other ones.

\subsection{Conclusions}

As for the obstacles observed for environmental proactivity; the most important one is the short financial support $(72,22 \%)$, followed by lack of institutional support $(64,44 \%)$ and Lack of tools information $(54,44 \%)$. This perception is common for all groups of companies, except for big enterprises, Lack of institutional support $(68,24 \%)$ is the biggest problem followed in this case by short financial support $(62,86 \%)$ and Lack of tools information $(57,65 \%)$

As for the benefits observed of environmental proactivity, the major one is to avoid sanctions $(85,56 \%)$ followed by the improvement of corporate image $(78,89 \%)$, long-term cost savings $(77,78 \%)$ and long-term economic benefits $(74,44 \%)$. It is important to point out, that for those companies with highly implicated management, the most important benefit perceived is long-term cost savings (90\%), the second one is improvement of corporate image $(88,33 \%)$ and the third one is to avoid sanctions $(86,67)$.

The Analysis conducted to the Spanish food sector, with the deep analysis of these Surveys, and all qualitative information obtained after the personal interviews, verifies the internal 
factors driving environmental proactivity Gonzalez-Benito and González-Benito (2006) determined. With the In-depth study of other sectors, and the comparison between the results of these studies, we could get more information about firm's external factors that also promote environmental proactivity.

As the aim of this study is to analyze the causes of problems, to suggest potential areas for improvement, as final conclusions the following suggestions could be made, these emerge from the observation of the obstacles to environmental proactivity, their facilitators, and the potential benefits of its application: improving the funding of companies so they can deepen environmental proactivity ; improving institutional support for environmental issues; awareness of managers and shareholders on matters of environment, where there is agreement about the need to act (Michaels and Furuseth 1997), as a value generating element to take into account because of its potential to improve the corporate image and for its resource optimization and cost savings possibilities. Adoption of Environmental Management Systems, as ISO 14001, results in a more cost-effective production. (Ratnasingam and Wagner 2010)

There are studies that show that the EU food industry's competitiveness is weak (Wijnands et al. 2008). These measures to support environmental proactivity would be rewarded with improvements arising from the potential benefits of its application. Following the contingency approach developed by Lawrence and Lorsch (1967) applied to the food sector. Some are short-term benefits, other longer-term, but all in the end profitable to maintain a sustained growth of business and by extension of society (Sharma and Vredenburg 1998, GonzálezBenito and González-Benito 2006, Melnyk et al. 2003 and Aragón-Correa et al. 2008), increasing companies competitiveness (Lopez-Gamero et al. 2008) and therefore contributing to the economy improvement.

\section{Acknowledgements}

The authors acknowledge the financial aid received from the Spanish Ministry of Science and Innovation through research Project reference no. EC02008-05895-C02-01/ECON, submitted to the 2008 Call for Grants for R\&D projects. 
Table 4.1 Facilitators identification

\begin{tabular}{|c|c|c|c|c|c|c|c|}
\hline \multirow{2}{*}{ - } & \multicolumn{2}{|c|}{$\begin{array}{l}\text { Company size } \\
\text { facilitator }\end{array}$} & \multicolumn{2}{|c|}{$\begin{array}{l}\text { Internationalization } \\
\text { facilitator }\end{array}$} & \multicolumn{2}{|c|}{$\begin{array}{l}\text { Management implication } \\
\text { facilitator }\end{array}$} & \multirow{2}{*}{$\begin{array}{l}- \\
\text { Total }\end{array}$} \\
\hline & $\begin{array}{l}\text { Small } \\
\text { and } \\
\text { medium }\end{array}$ & Big & National & Multinational & $\begin{array}{l}\text { Low } \\
\text { implication }\end{array}$ & $\begin{array}{l}\text { High } \\
\text { implication }\end{array}$ & \\
\hline Energy saving & $69,09 \%$ & $80,00 \%$ & $72,31 \%$ & $76,00 \%$ & $70,00 \%$ & $75,00 \%$ & $77,65 \%$ \\
\hline $\begin{array}{l}\text { Usage of } \\
\text { ecological products } \\
\text { in production }\end{array}$ & $32,73 \%$ & $37,14 \%$ & $27,69 \%$ & $52,00 \%$ & $16,67 \%$ & $43,33 \%$ & $36,47 \%$ \\
\hline Water saving & $69,09 \%$ & $80,00 \%$ & $70,77 \%$ & $80,00 \%$ & $60,00 \%$ & $80,00 \%$ & $77,65 \%$ \\
\hline Waste managed & $81,82 \%$ & $97,14 \%$ & $84,62 \%$ & $96,00 \%$ & $76,67 \%$ & $93,33 \%$ & $92,94 \%$ \\
\hline $\begin{array}{l}\text { Recyclable } \\
\text { products }\end{array}$ & $72,73 \%$ & $74,29 \%$ & $72,31 \%$ & $76,00 \%$ & $63,33 \%$ & $78,33 \%$ & $77,65 \%$ \\
\hline $\begin{array}{l}\text { Training in } \\
\text { environmental } \\
\text { matters }\end{array}$ & $47,27 \%$ & $71,43 \%$ & $52,31 \%$ & $68,00 \%$ & $50,00 \%$ & $60,00 \%$ & $60,00 \%$ \\
\hline $\begin{array}{l}\text { Ecological reasons } \\
\text { used in marketing }\end{array}$ & $30,91 \%$ & $37,14 \%$ & $35,38 \%$ & $28,00 \%$ & $20,00 \%$ & $40,00 \%$ & $35,29 \%$ \\
\hline $\begin{array}{l}\text { Environmental } \\
\text { costs and savings } \\
\text { quantified }\end{array}$ & $67,27 \%$ & $85,71 \%$ & $72,31 \%$ & $80,00 \%$ & $70,00 \%$ & $76,67 \%$ & $78,82 \%$ \\
\hline $\begin{array}{l}\text { Information of } \\
\text { measures taken } \\
\text { externally reported }\end{array}$ & $32,73 \%$ & $42,86 \%$ & $38,46 \%$ & $32,00 \%$ & $33,33 \%$ & $38,33 \%$ & $38,82 \%$ \\
\hline $\begin{array}{l}\text { Information of } \\
\text { measures taken } \\
\text { internally reported }\end{array}$ & $50,91 \%$ & $80,00 \%$ & $58,46 \%$ & $72,00 \%$ & $53,33 \%$ & $66,67 \%$ & $65,88 \%$ \\
\hline $\begin{array}{l}\text { Knowledge of } \\
\text { environmental } \\
\text { management } \\
\text { systems }\end{array}$ & $69,09 \%$ & $88,57 \%$ & $72,31 \%$ & $88,00 \%$ & $70,00 \%$ & $80,00 \%$ & $81,18 \%$ \\
\hline $\begin{array}{l}\text { Implementation of } \\
\text { environmental } \\
\text { management } \\
\text { systems }\end{array}$ & $61,82 \%$ & $82,86 \%$ & $66,15 \%$ & $80,00 \%$ & $63,33 \%$ & $73,33 \%$ & $74,12 \%$ \\
\hline
\end{tabular}


Table 4.2 Obstacles for environmental proactivity

\begin{tabular}{||l|l|l|l|l|l|l|l||}
\hline \hline- & \multicolumn{2}{|l||}{ Company size facilitator } & \multicolumn{2}{l||}{ Internationalization facilitator } & \multicolumn{2}{l|}{ Management implication facilitator } & - \\
\hline- & $\begin{array}{l}\text { Small and } \\
\text { medium }\end{array}$ & Big & National & Multinational & $\begin{array}{l}\text { Low } \\
\text { implication }\end{array}$ & $\begin{array}{l}\text { High } \\
\text { implication }\end{array}$ & Total \\
\hline $\begin{array}{l}\text { Short financial } \\
\text { support }\end{array}$ & $78,18 \%$ & $62,86 \%$ & $73,33 \%$ & $76,00 \%$ & $73,33 \%$ & $71,67 \%$ & $72,22 \%$ \\
\hline $\begin{array}{l}\text { Lack } \\
\text { institutional } \\
\text { support }\end{array}$ & $67,27 \%$ & $68,24 \%$ & $66,67 \%$ & $68,00 \%$ & $63,33 \%$ & $65,00 \%$ & $64,44 \%$ \\
\hline $\begin{array}{l}\text { Lack of tools } \\
\text { information }\end{array}$ & $56,36 \%$ & $57,65 \%$ & $50,00 \%$ & $64,00 \%$ & $53,33 \%$ & $55,00 \%$ & $54,44 \%$ \\
\hline $\begin{array}{l}\text { Lack of qualified } \\
\text { human resources }\end{array}$ & $52,73 \%$ & $49,41 \%$ & $45,00 \%$ & $52,00 \%$ & $46,67 \%$ & $46,67 \%$ & $46,67 \%$ \\
\hline $\begin{array}{l}\text { Lack of technical } \\
\text { solutions }\end{array}$ & $56,36 \%$ & $54,12 \%$ & $50,00 \%$ & $52,00 \%$ & $40,00 \%$ & $56,67 \%$ & $51,11 \%$ \\
\hline
\end{tabular}


Table 4.3 Benefits for environmental proactivity

\begin{tabular}{|c|c|c|c|c|c|c|c|}
\hline - & Company size facilita & & $\begin{array}{l}\text { Internatio } \\
\text { facilitator }\end{array}$ & alization & $\begin{array}{l}\text { Management } \\
\text { facilitator }\end{array}$ & implication & \\
\hline- & $\begin{array}{l}\text { Small and medium } \\
\text { enterprises }\end{array}$ & $\begin{array}{l}\text { Big } \\
\text { Enterprises }\end{array}$ & National & Multinational & $\begin{array}{l}\text { Low } \\
\text { implication }\end{array}$ & $\begin{array}{l}\text { High } \\
\text { implication }\end{array}$ & Total \\
\hline $\begin{array}{l}\text { Long-term economic } \\
\text { benefits }\end{array}$ & $69,09 \%$ & $82,86 \%$ & $66,67 \%$ & $88,00 \%$ & $56,67 \%$ & $83,33 \%$ & $74,44 \%$ \\
\hline Long-term cost savings & $76,36 \%$ & $80,00 \%$ & $73,33 \%$ & $84,00 \%$ & $53,33 \%$ & $90,00 \%$ & $77,78 \%$ \\
\hline $\begin{array}{l}\text { Improvement of } \\
\text { corporate image }\end{array}$ & $72,73 \%$ & $83,53 \%$ & $75,00 \%$ & $84,00 \%$ & $60,00 \%$ & $88,33 \%$ & $78,89 \%$ \\
\hline $\begin{array}{ll}\text { New } & \text { business } \\
\text { opportunities } & \end{array}$ & $63,64 \%$ & $69,41 \%$ & $61,67 \%$ & $72,00 \%$ & $50,00 \%$ & $73,33 \%$ & $65,56 \%$ \\
\hline Increase of customers & $63,64 \%$ & $61,18 \%$ & $56,67 \%$ & $60,00 \%$ & $43,33 \%$ & $65,00 \%$ & $57,78 \%$ \\
\hline $\begin{array}{l}\text { Competitiveness } \\
\text { increase }\end{array}$ & $67,27 \%$ & $70,59 \%$ & $63,33 \%$ & $72,00 \%$ & $43,33 \%$ & $78,33 \%$ & $66,67 \%$ \\
\hline $\begin{array}{l}\text { Short-term economic } \\
\text { benefits }\end{array}$ & $65,71 \%$ & $55,29 \%$ & $48,33 \%$ & $52,00 \%$ & $40,00 \%$ & $58,33 \%$ & $52,22 \%$ \\
\hline Short-term cost savings & $65,71 \%$ & $51,76 \%$ & $41,67 \%$ & $56,00 \%$ & $33,33 \%$ & $56,67 \%$ & $48,89 \%$ \\
\hline Avoid sanctions & $91,43 \%$ & $90,59 \%$ & $83,33 \%$ & $96,00 \%$ & $83,33 \%$ & $86,67 \%$ & $85,56 \%$ \\
\hline
\end{tabular}




\section{References}

Albors-Garrigós J, Hervás-Oliver JL (2006). La industria cerámica europea en el siglo XXI. Retos tecnológicos y desafíos de la próxima década. Boletín Sociedad Española. Cerámica.. V., 45, 1, 13-21.

Álvarez Gil MJ, De Burgos Jiménez J, Céspedes Lorente JJ (2001). Un análisis exploratorio de las estrategias medioambientales y el contexto organizativo de los hoteles españoles, Cuadernos de Economía y Dirección de la Empresa, núm. 8, pp. 5-32.

Amadieu P, Viviani J P (2010). Intangible Effort and Performance: The Case of the French Wine industry. Agribusiness Vol. 26 (2) 280-306.

Aragón-Correa JA, Hurtado-Torres N, Sharma S, García-Morales VJ (2008). Environmental strategy and performance in small firms: A resource-based perspective. Journal of Environ Management, Vol. 86, 1.

Azzone G, Bertele U, (1994). Exploiting Green Strategies for Competitive Advantage, Long Range Planning, Vol. 27, No. 6, pp. 69-81

Banerjee SB (2002) Corporate environmentalism, the construct and its measurement. Journal of Total Business Research Vol. 55, pp. 177-191.

Banerjee SB, Iyer SY, Kashyap RK (2003) Corporate environmentalism Antecedents and influence of industry type. Journal of Marketing Vol. 67, pp. 106-122.

Billiot MJ, Daughtrey ZW (2001) Evaluating Environmental Liability through Risk Premium Charged on Loans to Agribusiness Borrowers. Agribusiness, Vol. 17 (2), 273 297.

Bravo Gil R, Fraj Andrés , Martínez Salas E. (2005). La importancia del factor medioambiental en las estrategias corporativa y de marketing: una aplicación al sector de bienes de consumo. Cuadernos de estudios empresariales, No 15, 199-224.

Buil-Carrasco I, Fraj-Andrés E, Martínez-Salinas E, Matute-Vallejo J, (2005) Tipología de empresas medioambientales en el sector de bienes de consumo final. Revista de economía y empresa, $n^{\circ} 54$ y 55, Vol. XXIII (2 época), $2^{\circ}$ y 3er cuatrimestre, 69-93.

Carretero Peña AA (2009). Aplicación de la Norma UNEE 150008:2008 para la realización de Análisis de Riesgos Medioambientales en el contexto de la ley 26/2007 de Responsabilidad Medioambiental. Boletín Sociedad. Española. Ceramica. V., 48, 4, 7-8.

Christmann P (2000). Effects of 'best practices' of environmental management on cost advantage: The role of complementary assets. Academy of Management Journal, 43, 663-680.

Da Silva EM, Jabbour CJC, Santos FCA (2009). Integrating environmental management and manufacturing strategy: an emerging competitive priority. International Journal of Environmental Technology and Management. V.10, No 3, pp. 397 - 411.

Dowell G, Hart S, Yeung B (2000). Do corporate global environmental standards create or destroy market value? Management Science, 46: 1059-1074.

Dubé L, Paré G (2003). Rigor in information systems positivist case research: current practices, trends, and recommendations. Mis Quarterly, Vol. 27, $N^{\circ} 4$, pp. 597-635

Fairchild R, (2008). The Manufacturing Sector's Environmental Motives: A Game-theoretic Analysis. Journal of Business Ethics, Vol. 79, No. 3, pp. 333-344.

Fernández-Olmos M, Rosell-Martínez J, Espitia-Escuer M (2009). Vertical Integration in the Wine Industry: A Transaction Costs Analysis on the Rioja DOCa. Agribusiness, Vol. 25 (2) 231-250 (2009)

FIAB Federación española de industria de la alimentación y bebidas (2010) Economic report 2009. www.fiab.es/es/zonadescargas/industria.

Flyvbjerg B, (2006). Five Misunderstandings About Case-Study Research. Qualitative Inquiry.Vol. 12 No 2, pp. 219-245

Fritz M, Schiefer G (2008). Food Chain Management for Sustainable Food System Development: A European Research Agenda. Agribusiness, Vol. 24 (4), 440-452. 
Fundación Entorno (2003). Entorno 2003. Informe sobre la gestión ambiental en la empresa española. Avances hacia la sostenibilidad. Madrid.

Galdeano-Gómez E, (2008) Does and Endogenous Relationship Exist between Environmental and Economic Performance? A Resource-Based view on the horticultural sector. Environ Resource Econ, 40:73-89 DOI 10.1007/s10640-007-9141-4

González Benito J, González Benito O., (2005). Environmental proactivity and business performance: an empirical analysis. Omega International. Journal of Management Science, Vol. 33. No 1, pp.1-15.

González Benito J, González Benito O, (2006) A review of determinant factors of environmental proactivity, Bus Strat and the Envir, 15, 87-102.

Hitchens D, Thankappan S, Trainor M, Clausen J, De Marchi B (2005) Environmental performance, competitiveness and management of small businesses in Europe. Tijdschrift voor economische en sociale geografie. Vol. 96, No. 5, pp. 541-557.

Hunt CB, Auster ER, (1990). Proactive environmental management: avoiding the toxic trap, Sloan Management Review 31 (2), pp. 7-18.

Ingenleek P, Meulenberg MTG (2006). The Battle between Good and Better: A strategic Marketing Perspective on Codes of Conduct for Sustainable Agriculture. Agribusiness, Vol. 22 (4), 451-473.

Kalantari K, Asadi A (2010) Designing a structural model for explaining environmental attitude and behavior of urban residents (Case of Tehran). Int. J. Environ. Res., 4 (2), pp. 309-320.

King N (1994) "The qualitative research interview", pp. 14-36. En Qualitative methods in organizational research, Cassel, C. y Simon G. Eds. Sage Publications, Ltd. London.

Lawrence PR, Lorsch JW (1967) Organization and Environment Managing Differentiation and Integration. Boston, MA: Harvard University.

Liu X, Liu B, Shishime T, Yu Q, Bi J, Fujitsuka T (2010) An empirical study on the driving mechanism of proactive corporate environmental management in China. Journal of Environmental Management. Journal of Environmental Management, Vol 91, pp.1707-1717

López-Gamero MD, Claver-Cortes E, Molina-Azorín JF (2008): Complementary Resources and Capabilities for an Ethical and Environmental Management: A Qual/Quan Study. Journal of Business Ethics(2008) 82:701-732 DOI 10.1007/s10551-007-9587-x.

Martin-Tapia I, Aragón-Correa JA, Rueda-Manzanares A, (2009) Environmental strategy and exports in medium, small and micro-enterprises Journal of World Business. In press doi: 10.1016/j.jwb.2009.09.009.

McKeiver C, Gadenne D, (2005) Environmental management systems in small and medium businesses, International Small Business Journal, V. 23, n 5, 513-537.

Melnyk SA, Sroufe RP, Calantone R, (2003) Assessing the impact of environmental management systems on corporate and environmental performance Journal of Operations Management. Vol. 21, No 3, 329-351.

Mezquita A, Monfort E, Zaera V (2009) Sector azulejero y comercio de emisiones: reducción de emisiones de $\mathrm{CO} 2$, benchmarking europeo. Bol. Soc. Esp. Ceram. V., 48, 4, 211-222.

Michaels S, Furuseth OJ (1997). Innovation in environmental policy: the National Environmental Policy Act of the US and the Resource Management Act of New Zealand. The Environmentalist 17, 181-190.

Murillo, Garcés, Rivera (2004) Estrategia empresarial y medio ambiente: opinión de un grupo de expertos, Universia Business Review-Actualidad económica, cuarto trimestre, 52-63.

Mitchell R, Com MA, Wooliscroft B, Higham J (2010). Sustainable Market Orientation: A New Approach to Managing Marketing Strategy. Journal of Macromarketing, doi:10.1177/0276146710361928. 
Noci G, Verganti R, (1999) 'Managing Green' product innovation in small firms. $R \& D$ Management 29, 1

Peteraf M (1993) The cornerstone of competitive advantage: a resource based view, Strategic Management Journal, Vol. 14, pp. 179-191.

Porter ME, Van der Linde C, (1995) Toward a new conception of the environment competitiveness relationship, J. of Econ Persp, 9 (4), 97-118.

Ratnasingam J, Wagner K (2010) The Impact of ISO 14001 on the Operations Management of Wooden Furniture Manufactureres in Malaysia. Eur. J. Wood Prod. 68:479-481 DOI 10.1007/s00107-009-0370-9.

Roome N (1994) Business strategy, R\&D management and environmental imperatives, $R \& D$ Management 24, Vol. 1, pp. 65-82

Russo MV, Harrison NS (2005) Organizational design and environmental performance: clues from the electronics industry. Academy of Management Journal, V. 48, No 4, pp. 582-593.

Schaefer A, Harvey B, (1998) Stage models of corporate 'greening': a critical evaluation. Business Strategy and the Environment 7(3), 109-123.

Segarra-Oña M, Segura B, Martínez M (2009) La integración de la proactividad medioambiental en la estrategia empresarial: un estudio empírico. XI Reunión de Economía mundial. Congress proc. (I.S.B.N.: 1887-9489)

Segarra-Oña M, Peiro-Signes A, Albors-Garrigos J, Miret-Pastor L (2011): "Impact of innovative practices in environmentally focused firms. Moderating factors" Int. J. Environ Res., 5 (2), Forthcoming

Sharma S, Aragón-Correa JA Rueda-Manzanares A (2007) The contingent influence of organizational capabilities on proactive environmental strategy in the service sector: an analysis of North American and European ski resorts. Canada Journal of Administrative Sciences, V. 24, pp. 268-283.

Sharma S, Vredenburg H (1998) Proactive corporate environmental strategy and the development of competitively valuable organisational capabilities. Strategic Management Journal Vol. 19, pp. 729-753.

Singh RK, Murty HR, Gupta SK, Dikshit AK (2008) Development and implementation of environmental strategies for steel industry, Int. J. Environmental Technology and Management, Vol. 8, No. 1, pp. 69-86.

Smith AD (2010) Growth of corporate social responsibility as a sustainable business strategy in difficult financial times. International Journal of Sustainable Economy Vol. 2, No 1, pp.59-79

Stake RE (1995) The art of case study research. Thousand Oaks, CA. Sage.

Telle K, Larsson J (2007). Do environmental regulations hamper productivity growth? How accounting for improvements of plants' environmental performance can change the conclusion. Ecological Economics, Vol. 61, pp. 438-445.

Vastag G, Kerekes S Rondinelli DA (1996) Evaluation of corporate environmental management approaches: A framework and application. International Journal of Production Economics.V. 43, No 2-3, pp. 193-211.

Verbeke A, Bowen F, Sellers M (2006). Corporate environmental strategy: extending the natural resource-based view of the firm. Acad of Management Best Paper

Walker H, Di Sisto L, McBain D (2008). Drivers and barriers to environmental supply chain management practices: lessons from the public and private sectors. $J$. of

Purchasing \& Supply Management, Vol. 14, pp. 69-85.

Wijnands JHM, Bremmers HJ, Van der Meulen BMJ, Poppe KJ (2008) An Economic and Legal Assessment of the EU Food Industry's Competitiveness. Agribusiness, Vol. 24 (4), 417-439

Winsemius P, Guntram U (1992) Responding to the environmental challenge, Business Horizons 35 (2), pp. 12-20. 


\section{CAPÍtULLO 3}

IS IT POSSIBLE TO GENERATE ADDED VALUE THROUGH A HIGHER ENVIRONMENTAL PROACTIVITY ORIENTATION? A PRACTICAL ANALYSIS OF THE SPANISH CERAMIC INDUSTRY. 


\title{
IS IT POSSIBLE TO GENERATE ADDED VALUE THROUGH A HIGHER ENVIRONMENTAL PROACTIVITY ORIENTATION? A PRACTICAL ANALYSIS OF THE SPANISH CERAMIC INDUSTRY
}

\author{
Conrado Carrascosa-López ${ }^{1,2}$, María-del-Val Segarra-Oña ${ }^{1,2,3}$, Ángel Peiró-Signes ${ }^{1,2}$, Luis \\ Miret-Pastor $^{1,4}$, Baldomero Segura-García-del-Río ${ }^{1,4}$ \\ ${ }^{1}$ Universitat Politècnica de València \\ ${ }^{2}$ Management Department \\ ${ }^{3}$ INERTE, International Network for Research on Tourism and Environment. \\ ${ }^{4}$ Social Sciences Department
}

\begin{abstract}
maseo@omp.upv.es, concarlo@upvnet.upv.es, anpeisig@omp.upv.es, luimipas@esp.upv.es, bsegura@upvnet.upv.es
\end{abstract}

\begin{abstract}
Environmental proactivity is actually one of the key aspects considered in the strategic dimension related to corporate social responsibility of companies. The aim of this work is to analyze if it is possible to generate added value through a higher environmental proactivity orientation. The empirical application focuses on the Spanish ceramic industry allocated in Castellón. The objective of the research is to know which aspects determine company's environmental strategy, which are the barriers and facilitators that enable proactive environmental orientation of the industry studied and to verify what benefits companies can obtain from its application using a qualitative methodology. The main obstacles that companies find when looking for a more proactive environmental attitude are the lack of institutional and financial support. As for the benefits observed of environmental proactivity, the major one is to avoid sanctions, followed by improving the corporate image, the saving of long-term costs and obtaining new opportunities of business. There are several indicators that show that environmental proactivity is a value taken into account in the strategic planning of companies.
\end{abstract}

Keywords: Environmental proactivity, Sustainable development, Ceramic industry.

\section{Introduction}

Actually, it is crucial to evaluate the point to which the environmental factor is part of the business strategy of companies [41], how companies incorporate their environmental orientation is an emerging competitive priority in manufacturing strategy [8]. Environmental proactivity offers a vision of progress that integrates immediate and longer term objectives as well as local and global action, and regards social, economic and environmental issues as inseparable and interdependent components of human progress [30].

A growing number of companies consider aspects tied to sustainable development, environmental attitude, eco-innovation or environmental management to be a first-class asset on a strategic level $[8,10,30]$. In this context, management of sustainable development becomes a crucial process.

The industrial sector has repeatedly been responsible for assaults on the environment, which have been reduced over the years due to the growing environmental awareness of the sector and the implementation of laws and guidelines to control the level of pollution caused by industries [11]. These changes give rise to the implementation in companies of different environmental strategies [15] from environmental responsiveness to environmental proactivity.

Several research papers have studied how environmental management tools affect firm competitiveness; Russo and Harrison [33] found that incentives could be a valuable tool for improving environmental performance and, then, environmental promotion could be an opportunity to shape an organization's redesign to be more proactive. McKeiver \& Gadenne [22] analyzed both, the external and internal factors affecting the implementation of an 
environmental management system. Other authors studied how competitive advantages could be gained through environmental orientated activities [38] or how firms' performance could be improved [15, 27].

Companies need to differentiate through sustainability is becoming more and more important, but there is still no scientific basis to carry out its measure. Consequently, it is necessary to analyze the environmental factor as a proactive aspect of company's management, as well as the determining factors encouraging a company to move towards environmental protection in what come to be called "corporate environmentalism" [4, 5]. Several authors have analyzed the integration of the environmental factor in business strategy [16]. On a general level, the influence of factors such as social pressure [18], environmental legislation [36], competitive advantages and management's commitment to the company's environmental focus [33] and also aspects as its strategies have been studied $[6,24,47]$.

\subsection{Objectives and structure}

Several studies on business proactivity applied on industries can be found. On a Spanish level, Aragón-Correa et al [2] found that in the automotive repair sector, the economic performance of companies with more proactive practices was improved. In the work performed by Martín-Tapia et al [21], the food industry was studied and a correlation between advanced environmental strategies and the export level of the SMEs was found. Currently, there is a need to analyze the actual inclusion of environmental proactivity in the global strategy of organizations as a differentiating element and hence, creator of competitive advantages, by analyzing the extent to which the environmental factor forms part of the business strategy.

Taking these into account, the main objective of this research is to analyze the environmental factor as a proactive aspect of company management and identify the factors that help companies to move towards sustainable management; the specific objectives being the identification of the factors characterizing environmental performance and the identification of the facilitators and difficulties encountered by companies with respect to their environmental management [47].

The study has been performed on the Spanish ceramic industry by analyzing the companies' performance in order to identify improvement actions.

This research examines the existing literature on environmental proactivity, environmental strategy and environmental determinants in the industry in order to identify the most representative issues affecting the decisions made in companies in the ceramic industry. In this work, actions taken by a set of 14 ceramic companies, a heterogeneous group of national and multinational companies were considered; all of them have in common the location in the ceramic cluster located in the surroundings of Castellón.

A questionnaire to measure environmental integration [37] was applied, used as a tool for guiding semistructured interviews as case-study method can certainly contribute to the cumulative development of knowledge $[13,42]$. The results of the interviews conducted with the environmental heads of the companies studies were then analyzed, differentiating between the type of company (national, multinational and size). Findings were determinant since differences between companies belonging to the same industry were explained. Then, the analysis and discussion of the results are presented. The work finishes with a summary of the conclusions.

\subsection{Literature review on environmental strategy}

Different classifications have been made according to their environmental strategy, however, in general, four groups have been defined in terms of endogenous and exogenous environmental risks: reactive, proactive, strategic and preventive [14, 45, 48].

In order to identify those factors to be taken into account for classification purposes, Fundación Entorno [13] classifies companies as: leaders, those who see the environment as an opportunity to innovate and improve; enthusiasts, those that implement environmental management and prevention systems; proactive, those that integrate environmental aspects into their operations and are very attuned to and take advantage of opportunities offered by the environment; reactive, those that react to the environmental obligations and make decisions to comply with the law in force; and indifferent, those that find it hard to take the necessary measures and do not feel committed but rather negative, seeing environmental concern as a threat hampering operations. Several classifications have been made attending different criteria, Hunt \& Auster [28], as beginner, fighter, concerned citizen, pragmatist or proactivist, Winsemius\&Guntram [48] as reactive, receptive, constructive proactive, Roome [31], as non-compliance, compliance, compliance plus, excellence and leading edge, Azzone\&Bertelé [3] as stable, reactive, anticipatory, proactive, creative, Vastag, Kerekes\&Rondinelli [45], as reactive, crisis preventive, strategic or proactive, Schaefer\&Harvey [34] as beginner, fighter, concerned citizen, pragmatic and proactive and 
González-Benito\& González-Benito [14] as reactive, pro-certification, pro-design, pro-logistics and procommercial.

The combination of the resource based theory, RBV [29], with the adoption of environmental strategies has also been considered, through the development of an integrated framework for analyzing the relationship between environmental strategies and the development of the company's specific environmental capabilities $[9,39,41$, 46].

Though they may appear to be different, they all have points in common in that they analyze the strategic positioning in different intermediate states between the most reactive and most proactive point of view. On the other hand, factors determining the proactive environmental orientation have been classified as internal aspects of the company (size, level of internationalization, position on the value change, attitude of the management as well as the motivation and strategic attitude of the company), external (sector and Geographic location) and as a determining factor, the pressure of the shareholders/owners [15]. Also, Murillo, et al. [26], classifies the factors as external (legislation, clients, vendors, companies in the sector, financial entities, insurers, media, ecologists and/or citizens or nearby communities; and internal (management, partners and shareholders and/or employees).

Trying to identify factors affecting the environmental orientation adopted by companies, some studies have been developed. In the consumer goods sector, factors such as the influence of external pressure forces, environmental orientation, corporate and marketing strategies, size, macro-sector and whether or not the company has a marketing department were found to have an influence on which environmental strategy is adopted [7, 28]. Gonzalez-Benito \& González-Benito [14] identified several environmental proactivity strategies in three industrial sectors, electricity, chemicals and furniture, noting the multidisciplinary nature of environmental proactivity.

Although the studies performed to date are high quality and specialized works, there is not yet enough data which aids in identifying the aspects of environmental proactivity with an influence on business competitiveness nor is there sufficient scientific basis for carrying out its measurement.

The intention is to study particularly which is the influence of the facilitators of environmental proactivity in the ceramic sector and more particularly in companies of Castellón's cluster. The cluster is known as a model where the nearness of the companies and the support institutions promote important increases of competitiveness [28], although the companies present an individual performance, which meets affected by its pull of resources and capacities [18]. In this line and focusing on the evaluating of which concrete characteristics of the companies affect the environmental proactive orientation, we raise our hypotheses:

H1: Small size is a barrier to a company's environmental proactivity.

$\mathrm{H} 2$ : The multinational nature of a company facilitates its proactive orientation.

$\mathrm{H} 3$ : The direct implication of management is vital to facilitate proactive orientation.

\section{General perspective ceramic sector}

Spain is the second European producer of ceramic tiles and the third world exporter, behind China and Italy. The Spanish ceramic sector produced in 2009 324, 4 million of $\mathrm{m} 2$ of ceramic tiles, (37 \% of EU-27). It employs 17700 persons directly and more than 6000 indirectly. It exports to 182 countries for a total value of 1673 million Euros. Being the total sales of the sector of 2591 million Euros.

In 2008, the Spanish ceramic sector invoiced 3692 million Euros, which represents a decrease of 11, $37 \%$ turnover of the previous year. This fall has been especially sudden on the Spanish market, where the decrease of sales has been near to $22 \%$, whereas on the international markets the fall has been much softer, with a decrease of the sales near to $4 \%$. The provisional information of 2009 shows an even more accused decrease in the domestic market, (37\% respect 2008), and on the international markets, (24\% respect 2008). The decrease of international sales is explained in Europe and the USA due to the economic crisis, which could not have been compensated by significant increases in Africa, Eastern Europe and Middle East. In Spain the fall is major due to the strong contraction of the construction sector, and the most accused fall of the internal demand.

Fig. 1 Spanish ceramic sector sales (Million Euro). 2009*(Provisional date) 




Source: Compiled by author with data from ASCER

A characteristic of the Spanish ceramic sector is the high geographical concentration in Castellón's province $[1,44]$, since $94,5 \%$ of the Spanish national output is concentrated in the area delimited in the northern part by Borriol and Alcora, in the western part for Onda, in the southern part for Nules and in the eastern part for Castellon de la Plana. His importance in the Valencian Community is very big, since it has been for many years the first investing sector and the second exporter (only behind car manufactures).

\section{Methodology}

We have developed an explanatory case study methodology Kaplan [19] to try to figure out how the barriers and facilitators of environmental proactivity influence competitiveness. Fourteen cases were studied according to Rouse and Daellenbach [32].

The method to be used in this study, i.e. in-depth interviews, is classified as direct data collection [43]. The type of interview used is called a structured open-ended interview [20]. This technique combines the advantages of closed questionnaires with those of qualitative research interviews. Following [10] to have high rigor level when using case studies as the methodological research, some considerations have to be taken into account. We have followed their three areas structure when designing our study, firstly, aspects related with the design, as identifying clear research questions, taking advantage of pilot cases in order to help refine the design and the data, the collection plans, to conduct more longitudinal case studies and, exploiting the richness of the various data collection methods. Secondly, questions regarding with data collection as to provide detailed information with respect to the data collection methods, procedures aspects as number of interviews, and interviewees, use of an interview, guide, instrument validation etc, the effectively use of tables to summarize information about the data collection process or how to triangulate data in order to increase internal validity of the findings and provide clear explanations on how the triangulation process is achieved. And last, data analysis procedures in order to provide clear descriptions of the analytic methods and procedures, make greater use of preliminary data analysis techniques and tools and compare findings with extant literature (both similar and conflicting) in exploratory case research so as to increase the confidence in the findings.

Following Flyvbjerg [12], when the objective is to achieve the greatest possible amount of information on a given problem or phenomenon, atypical or extreme cases reveal more information, for that reason we studied the company leader of the cluster, Porcelanosa among the chosen firms. Another tile manufacturer competitors and auxiliary companies all of them belonging to the ceramic cluster in Castellón.

A Likert scale questionnaire was prepared with five possible answers and an additional alternative answer indicating there is not enough criteria to answer. The questionnaire was filled in personally by the authors of the study in order to characterize the company in terms of its level of environmental proactivity and to establish a system for measuring the integration of environmental proactivity in the company's business strategy.

On the other hand, since the interview is conducted personally by one of the researchers, an attempt is made to gather qualitative information not directly related to the specific questions included in the questionnaire by means of informal talks with employees of the company, identification of information/internal training, and examination of the company's products and manufacturing processes [43]. 
The questionnaire consists of a total of 42 questions focused on identifying the aspects enabling the company to be characterized in terms of its environmental proactivity, and also those aspects of organization enabling a system to be established for the measurement of the integration of environmental proactivity in the companies' business strategy.

Before its final circulation, the questionnaire was submitted to a pretest to verify and discuss the appropriateness of the questions. The interviews are conducted by means of personal interviews with the directors or managers of companies rather than by post in order to make the results obtained more reliable. Proximity to reality, which the case study entails, and the learning process that it generates for the researcher will often constitute a prerequisite for advanced understanding [12].

\section{Results analysis}

The group of studied companies is composed of 14 companies all of them belonging to Castellón's ceramic cluster. The sample is mixed, $50 \%$ of the companies are multinational, and other one $50 \%$ are national. They have been gathered in groups as for the size in small (less than 50 employees), medium (between 50 and 250), and large (more than 250 employees). $71 \%$ of the companies of the sample have own environmental management department, and $29 \%$ realize the tasks distributed between other departments. $71 \%$ of the companies have environmental accreditation already gained or are in process of obtaining it. It is important to emphasize that even two companies have patents related to environmental actions.

\subsection{Facilitators identification}

The internal company facilitators observed with the analysis of the realized surveys are three: The size of the company, (small, medium and large company), the characteristic of the company as for his internationalization (international or national), and the degree of implication of executives and shareholders, (High, major of $70 \%$, or fall, minor of $70 \%$ ).

In the following table, the environmental behavior of the companies is characterized, grouping them taking into account the facilitators before mentioned.

Table 1. Facilitator's identification (\%)

\begin{tabular}{|c|c|c|c|c|c|c|c|c|}
\hline & \multicolumn{3}{|c|}{$\begin{array}{l}\text { Company size } \\
\text { facilitator }\end{array}$} & \multicolumn{2}{|c|}{$\begin{array}{l}\text { Internationalization } \\
\text { facilitator }\end{array}$} & \multicolumn{2}{|c|}{$\begin{array}{c}\text { Management } \\
\text { involvement } \\
\text { facilitator }\end{array}$} & \multirow{2}{*}{ 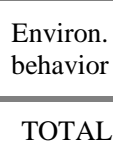 } \\
\hline & Small & Med. & Large & Internat. & Nat. & High & Low & \\
\hline Energy saving & 55 & 48 & 92 & 82,86 & 48,57 & 79,2 & 40 & 65,71 \\
\hline $\begin{array}{l}\text { Usage of ecological } \\
\text { products in } \\
\text { production }\end{array}$ & 55 & 40 & 56 & 65,71 & 34,29 & 53,6 & 45 & 50 \\
\hline Water saving & 60 & 76 & 84 & 91,43 & 57,14 & 84,4 & 55 & 74,29 \\
\hline Waste managed & 85 & 92 & 100 & 100 & 85,71 & 100 & 85 & 92,86 \\
\hline $\begin{array}{l}\text { Recyclable } \\
\text { products }\end{array}$ & 30 & 64 & 80 & 71,43 & 48,57 & 78 & 20 & 60 \\
\hline $\begin{array}{l}\text { Training in } \\
\text { environmental } \\
\text { matters }\end{array}$ & 55 & 32 & 72 & 62,86 & 42,86 & 61,2 & 40 & 52,86 \\
\hline $\begin{array}{l}\text { Ecological } \\
\text { arguments used in } \\
\text { marketing }\end{array}$ & 15 & 68 & 84 & 80 & 37,14 & 76,4 & 30 & 58,57 \\
\hline $\begin{array}{l}\text { Environmental } \\
\text { costs and savings } \\
\text { quantified }\end{array}$ & 30 & 52 & 80 & 57,14 & 54,29 & 72 & 25 & 55,71 \\
\hline $\begin{array}{l}\text { Information of } \\
\text { measures taken } \\
\text { externally reported }\end{array}$ & 25 & 32 & 44 & 51,43 & 17,14 & 46,4 & 10 & 34,29 \\
\hline $\begin{array}{l}\text { Information of } \\
\text { measures taken } \\
\text { internally reported }\end{array}$ & 25 & 24 & 56 & 45,71 & 25,71 & 49,6 & 10 & 35,71 \\
\hline
\end{tabular}


The aggregation of the surveys and the grouping of the companies according to the different facilitators allows us to see the influence of each one in each of the behaviors that characterize the environmental proactivity, that are detailed in the left column.

\subsection{Identification of obstacles to environmental proactivity.}

The main obstacles faced by companies when attempting to adopt a more proactive environmental strategy are, lack of institutional support $(65,71 \%)$, short financial support $(54,29 \%)$, lack of tools information $(51,43 \%)$, lack of technical solutions $(37,14 \%)$, and lack of qualified human resources $(33 \%)$.

In the following table, the obstacles to environmental proactivity of companies are characterized, grouping them taking into account the facilitators before mentioned.

Table 2. Obstacles to environmental proactivity (\%)

\begin{tabular}{lccccccccc}
\hline & \multicolumn{3}{c}{$\begin{array}{c}\text { Company size } \\
\text { facilitator }\end{array}$} & \multicolumn{2}{c}{$\begin{array}{c}\text { Internationalization } \\
\text { facilitator }\end{array}$} & $\begin{array}{c}\text { Management } \\
\text { involvement } \\
\text { facilitator }\end{array}$ & $\begin{array}{c}\text { Obstacles } \\
\text { to } \\
\text { proactivity }\end{array}$ \\
\hline & Small & Med. & Large & Internat. & Nat. & High & Low & TOTAL \\
\hline $\begin{array}{l}\text { Short financial } \\
\text { support }\end{array}$ & 65 & 64 & 36 & 45,71 & 62,86 & 41,6 & 75 & 54,29 \\
$\begin{array}{l}\text { Lack of institutional } \\
\text { support }\end{array}$ & 75 & 68 & 56 & 88,57 & 42,86 & 61,6 & 70 & 65,71 \\
$\begin{array}{l}\text { Lack of tools } \\
\text { information }\end{array}$ & 50 & 72 & 32 & 60 & 42,86 & 49,2 & 55 & 51,43 \\
$\begin{array}{l}\text { Lack of qualified } \\
\text { human resources }\end{array}$ & 25 & 44 & 28 & 45,71 & 20 & 30,8 & 35 & 32,86 \\
$\begin{array}{l}\text { Lack of technical } \\
\text { solutions }\end{array}$ & 15 & 52 & 40 & 57,14 & 17,14 & 46 & 10 & 37,14 \\
\hline
\end{tabular}

Again the aggregation of the surveys and the grouping of the companies according to the different facilitators allow us to see the influence of each one and the relation with each of the obstacles observed in the left column. This detailed info gives a deep and close overview of each group's needs.

\subsection{Identification of benefits of environmental proactivity}

The companies identify significant benefits arising from the implementation of proactive environmental management actions, the most important one is to avoid sanctions $(71,43 \%)$, followed by improvement of the corporate image $(68,57 \%)$.

Table 3 shows environmental proactivity benefits detected by the ceramic companies.

Table 3. Benefits of environmental proactivity (\%)

\begin{tabular}{|c|c|c|c|c|c|c|c|c|}
\hline & \multicolumn{3}{|c|}{$\begin{array}{l}\text { Company size } \\
\text { facilitator }\end{array}$} & \multicolumn{2}{|c|}{$\begin{array}{c}\text { Internationalizati } \\
\text { on } \\
\text { facilitator }\end{array}$} & \multicolumn{2}{|c|}{$\begin{array}{c}\text { Management } \\
\text { involvement } \\
\text { facilitator }\end{array}$} & \multirow{2}{*}{$\begin{array}{c}\text { Environ. } \\
\text { proactivity } \\
\text { benefits }\end{array}$} \\
\hline & Small & Med. & Large & Internat. & Nat. & High & Low & \\
\hline $\begin{array}{l}\text { Long-term economic } \\
\text { benefits }\end{array}$ & 35 & 64 & 60 & 71,43 & 37,14 & 62 & 30 & 54,29 \\
\hline Long-term cost savings & 35 & 72 & 68 & 68,57 & 51,43 & 70,8 & 30 & 60 \\
\hline $\begin{array}{l}\text { Improvement of } \\
\text { corporate image }\end{array}$ & 40 & 68 & 92 & 88,57 & 48,57 & 83,2 & 30 & 68,57 \\
\hline $\begin{array}{l}\text { New business } \\
\text { opportunities }\end{array}$ & 60 & 48 & 72 & 68,57 & 51,43 & 67,2 & 40 & 60 \\
\hline
\end{tabular}




\begin{tabular}{lcccccccc} 
Increase of customers & 25 & 52 & 52 & 51,43 & 37,14 & 55,2 & 10 & 44,29 \\
$\begin{array}{l}\text { Competitiveness } \\
\text { increase }\end{array}$ & 25 & 52 & 52 & 51,43 & 37,14 & 51,2 & 20 & 44,29 \\
$\begin{array}{l}\text { Short-term economic } \\
\text { benefits }\end{array}$ & 40 & 44 & 36 & 54,29 & 25,71 & 41,6 & 35 & 40 \\
$\begin{array}{l}\text { Short-term cost savings } \\
\text { Avoid sanctions }\end{array}$ & 55 & 44 & 64 & 71,43 & 25,71 & 58,4 & 30 & 48,57 \\
\hline
\end{tabular}

The aggregation of the surveys and the grouping of the companies according to the different facilitators allow us to see the influence of each one and the relation with each of the benefits observed in the left column.

\section{Conclusions and discussion}

\subsection{Modeling results and hypotheses testing}

The environmental proactivity of the ceramic industry cluster located in Castellón region was studied and the barriers and facilitators the companies consider as a key to the inclusion of proactive environmental actions in their business strategies were identified. Figure 4 shows the model developed by authors based on the fieldwork performed.

Fig. 4. Proactive performance model of the ceramic sector.

\section{Environmental management model ceramic sector companies}



Source: Compiled by authors.

With respect to the hypotheses made in the study, H1: Small size is a barrier to a company's environmental proactivity, this hypothesis is not verified. In table 1 , several factors to identify and to characterize the environmental behavior are observed, they show that there are small companies with a better environmental behavior than medium companies, and even comparable to the behavior of big companies. Evidently, the study is based on the companies of Castellón's ceramic cluster, due to this fact we can conclude that for these companies the size is not a barrier. What happens with our study is that the big size of a company is verified as a facilitator of environmental proactivity 
$\mathrm{H} 2$ : The multinational nature of a company facilitates its proactive orientation. This hypothesis is fulfilled because all multinational companies (Small, medium or large) have a better environmental behavior than national ones.

H3: The direct implication of management is vital to facilitate proactive orientation. This hypothesis is fulfilled because all companies with high involvement of management have a better environmental behavior than the other ones.

\subsection{Conclusion}

As for the obstacles observed for environmental proactivity, the major one is the lack of institutional support (66\%), followed by lack of financial support (54\%), and of lack of information of the tools (51\%). According to the observed company group, there are differences as for the perception of obstacles: The lack of institutional support is the major problem for small companies $(75 \%)$, international companies $(89 \%)$ and companies with poorly implicated management $(70 \%)$. The shortage of financial support is the major problem for the domestic enterprises $(63 \%)$, and for companies with poorly implicated management. The lack of information of the tools is the major problem for the medium companies.

As for the benefits observed of environmental proactivity, the major one is to avoid sanctions (71\%), followed by improving the corporate image $(68 \%)$, the saving of long-term costs $(60 \%)$ and obtaining new opportunities of business $(60 \%)$. According to the group of companies, there are differences in the perception of benefits of the environmental proactivity. To avoid sanctions is the major benefit waited for medium, national companies and with poorly implicated management. To improve the corporate image is the best benefit for big, international companies and with high implication of management. Whereas for small companies the major benefit is the possibility of obtaining new business opportunities.

To sum up, and according to the results obtained with the analyzed information, we can conclude that in Castellón's ceramic sector, many companies can be found that would be considered to be proactive, and even some as leaders. There are several indicators that show that environmental proactivity is a value taken into account in the strategic planning of companies. In this work we have highlighted the main actions that companies can work on to improve their environmental proactive orientation and improve their competitive resources set.

Nevertheless still possibilities of improvement are seen in the fields of institutional support and financial support basically. In the current circumstances of economic crisis, and seen the possible benefits that environmental proactivity can bring, its impulse might contribute with distinguishing factors to help companies exit of the crisis. These will lead our further research.

\footnotetext{
Acknowledgments. The authors would like to thank the Spanish Science and Innovation Ministry for its financial support through the research project (EC02011-27369). Also the Technical University of Valencia for its research funding to the project "Innovative impact on the companies' environmental performance: identifying moderating factors" (PAID-06-2011-1879) and for supporting the sabbatical research 2011-2012 course of M. Segarra.
}

\section{References}

[1] Albors-Garrigós J, Marquez-Rogríguez P, Segarra-Oña, M. (2009) Internet como herramienta de creación de valor en sectores maduros. El caso de los productores y distribuidores cerámicos en España. Análisis empírico de los factores moderadores. Bol. Soc. Esp. Ceram. V. 48 (6):279-288.

[2] Aragón-Correa J A, Hurtado-Torres N, Sharma S, García-Morales, VJ (2008) Environmental strategy and performance in small firms: A resource-based perspective. Journal of Environmental Management 86(1)

[3] Azzone G, Bertele U (1994) Exploiting Green Strategies for Competitive Advantage. Long Range Planning 27(6):69-81.

[4] Banerjee S B (2002) Corporate environmentalism. The construct and its measurement. Journal of Business Research 55:177-191.

[5] Banerjee S B, Iyer SY, Kashyap R K (2003) Corporate environmentalism. Antecedents and influence of industry type. Journal of Marketing 67:106-122.

[6] Buil-Carrasco I, Fraj-Andrés E, Martínez-Salinas E, Matute-Vallejo J (2005) Tipología de empresas medioambientales en el sector de bienes de consumo final. Revista de economía y empresa 54, 55(XXIII): 69-93.

[7] Christmann P (2000) Effects of best practices of environmental management on cost advantage: The role of complementary assets. Academy of Management Journal 43:663-680.

[8] Da Silva E M, Jabbour C J C, Santos F C A (2009) Integrating environmental management and manufacturing strategy: an emerging competitive priority. International Journal of Environmental Technology and Management 10(3):397-411.

[9] Dowell G, Hart S, Yeung B (2000) Do corporate global environmental standards create or destroy market value? Management Science 46:1059-1074. 
[10] Dubé L, Paré G (2003) Rigor in information systems positivist case research: current practices, trends, and recommendations. Mis Quarterly 27(4):597-635.

[11] Fairchild R (2008) The Manufacturing Sector's Environmental Motives: A Game-theoretic Analysis. Journal of Business Ethics 79(3):333-344.

[12] Flyvbjerg B (2006) Five Misunderstandings About Case-Study Research. Qualitative Inquiry 12(2):219-245.

[13] Fundación Entorno (2003) Entorno 2003. Informe sobre la gestión ambiental en la empresa española. Avances hacia la sostenibilidad. Fundación Entorno, Madrid.

[14] González Benito J, González Benito O (2005) Environmental proactivity and business performance: an empirical analysis. Omega Internacional. Journal of Management Science 33(1):1-15.

[15] González Benito J, González Benito O (2006) A review of determinant factors of environmental proactivity. Business Strategy and the Environment 15:87-102.

[16] Hitchens D, Thankappan S, Trainor M, Clausen J, De Marchi B (2005) Environmental performance, competitiveness and management of small businesses in Europe. Tijdschrift voor economische en sociale geografie 96(5):541-557.

[17] Hunt C B, Auster E R (1990). Proactive environmental management: avoiding the toxic trap. Sloan Management Review 31(2):7-18.

[18] Kalantari Kh, Asadi A (2010) Designing a structural model for explaining environmental attitude and behaviour of urban residents (Case of Tehran). Int. J. Environ. Res., 4(82):309-320.

[19] Kaplan, R S (1986) The role for empirical research in management accounting. Accounting, Organizations and Society.

[20] King N (1994) The qualitative research interview. Qualitative methods in organizational research, Cassel, C. y Simon G. Eds. Sage Publications, Ltd. London.

[21] Martin-Tapia I, Aragón-Correa J A, Rueda-Manzanares A (2009). Environmental strategy and exports in medium, small and micro-enterprises. Journal of World Business. In press doi: 10.1016/j.jwb.2009.09.009.

[22] McKeiver C, Gadenne D, (2005) Environmental management systems in small and medium businesses. International Small Business Journal 23(5):513-537.

[23] Melnyk S A, Sroufe R P, Calantone R, (2003) Assessing the impact of environmental management systems on corporate and environmental performance. Journal of Operations Management 21(3):329-351.

[24] Miret-Pastor, L., Segarra-Oña, M., Peiró-Signes, A. (2011), Identification of service sectors and high technology in Valencia: a new cluster mapping? (In Spanish: Identificación de sectores de servicios y de alta tecnología en la Comunidad Valenciana: ¿Un nuevo cluster mapping?). Revista de estudios regionales, 90: 71-96.

[25] Mitchell R, Com M A, Wooliscroft B, Higham J (2010) Sustainable Market Orientation: A New Approach to Managing Marketing Strategy. Journal of Macromarketing, doi:10.1177/0276146710361928.

[26] Murillo, Garcés, Rivera (2004) Estrategia empresarial y medio ambiente: opinión de un grupo de expertos. Universia Business Review- Actualidad económica, cuarto trimestre: 52-63.

[27] Noci G, Verganti R (1999) Managing green product innovation in small firms. R\&D Management 29(1).

[28] Peteraf M (1993) The cornerstone of competitive advantage: a resource based view. Strategic Management Journal 14:179-191.

[29] Peiró-Signes, A., Segarra-Oña, M., Miret-Pastor, L., Verma, R. (2011) Eco-innovation attitude and industry's tecnological level. An important key for promoting efficient vertical policies. Environmental Engineering and Management Journal.10 (12): 1893 1901.

[30] Porter M E, Van der Linde C (1995) Toward a new conception of the environment competitiveness relationship. Journal of Economic Perspectives 9(4):97-118.

[31] Roome N (1994) Business strategy, R\&D management and environmental imperatives. R\&D Management 24(1):65-82.

[32] Rouse M J, Daellenbach U S (1999) Rethinking research methods for the resource-based perspective: isolating sources of sustainable competitive advantage. Strategic Management Journal 20:487-494.

[33] Russo M V, Harrison N S (2005) Organizational design and environmental performance: clues from the electronics industry. Academy of Management Journal 48(4):582-593

[34] Schaefer A, Harvey B (1998) Stage models of corporate greening: a critical evaluation. Business Strategy and the Environment 7(3):109-123.

[35] Segarra-Oña M, Peiró-Signes A, Albors-Garrigós J, Miret-Pastor P (2011) Impact of Innovative Practices in Environmentally Focused Firms: Moderating Factors. Int.J.Environ.Res. 5:425-434

[36] Segarra-Oña, M., Carrascosa-López, C., Segura-García-del-Río, B., Peiró-Signes, A. (2011) Empirical analysis of the integration of environmental proactivity into managerial strategy. Identification of benefits, difficulties and facilitators at the Spanish automotive industry. Environmental Engineering and Management Journal.10 (12): 1821-1830.

[37] Segarra-Oña, M. Peiró-Signes, A., Miret-Pastor, L.,Albors-Garrigós, J. (2011) ¿Eco-innovación, una evolución de la innovación? Análisis empírico en la industria cerámica española Bol. Soc. Esp. Ceram. V. 50(5):253-260.

[38] Segarra-Oña, M., De Miguel Molina, B. (2009), Evaluación de la Concentración Industrial Sinérgica: propuesta metodológica y aplicación a un sector industrial, TEC Empresarial 65, 3 (1-2): 65-72.

[39] Sharma S, Vredenburg H, (1998) Proactive corporate environmental strategy and the development of competitively valuable organisational capabilities. Strategic Management Journal 19:729-753.

[40] Sharma S, Aragón-Correa J A, Rueda-Manzanares A (2007). The contingent influence of organizational capabilities on proactive environmental strategy in the service sector: an analysis of North American and European ski resorts. Canadian Journal of Administrative Sciences 24:268-283.

[41] Singh R K, Murty H R, Gupta S K, Dikshit A K (2008) Development and implementation of environmental strategies for steel industry. Int. J. Environmental Technology and Management 8(1):69-86.

[42] Smith A D (2010) Growth of corporate social responsibility as a sustainable business strategy in difficult financial times. International Journal of Sustainable Economy 2(1):59-79.

[43] Stake R E (1995) The art of case study research. Thousand Oaks, CA. Sage.

[44] Telle K, Larsson J (2007) Do environmental regulations hamper productivity growth? How accounting for improvements of plants environmental performance can change the conclusion. Ecological Economics 61:438-445.

[45] Vastag G, Kerekes S, Rondinelli D A (1996) Evaluation of corporate environmental management approaches: A framework and application. International Journal of Production Economics 43(2-3):193-211.

[46] Verbeke A, Bowen F, Sellers M (2006). Corporate environmental strategy: extending the natural resource-based view of the firm. Academy of Management Best Paper. 
[47] Walker H, Di Sisto L, McBain D (2008) Drivers and barriers to environmental supply chain management practices: lessons from the public and private sectors. Journal of Purchasing \& Supply Management 14:69-85.

[48] Winsemius P, Guntram U (1992) Responding to the environmental challenge, Business Horizons 35(2):12-20. 


\section{CAPÍtUlo 4}

EMPIRICAL ANALYSIS OF THE INTEGRATION OF ENVIRONMENTAL PROACTIVITY INTO MANAGERIAL STRATEGY. IDENTIFICATION OF BENEFITS, DIFFICULTIES AND FACILITATORS AT THE SPANISH AUTOMOTIVE INDUSTRY. 


\title{
EMPIRICAL ANALYSIS OF THE INTEGRATION OF ENVIRONMENTAL PROACTIVITY INTO MANAGERIAL STRATEGY. IDENTIFICATION OF BENEFITS, DIFFICULTIES AND FACILITATORS AT THE SPANISH AUTOMOTIVE INDUSTRY
}

\author{
María-del-Val Segarra-Oña ${ }^{1,3 *}$, Conrado Carrascosa-López ${ }^{1}$, \\ Baldomero Segura-García-del-Río ${ }^{2}$ Ángel Peiró-Signes ${ }^{1}$ \\ ${ }^{1}$ Universitat Politècnica de València, Management Department, Camino de Vera, s/n 46022 Valencia, Spain \\ ${ }^{2}$ Universitat Politècnica de València, Social Sciences and Economics Department, Camino de Vera, s/n 46022 Valencia \\ (Spain) \\ ${ }^{3}$ Globalization,Tourism and Heritatge Research Microcluster
}

\begin{abstract}
Industrial firms around the world are focusing on environmental sustainability seeking competitive advantages. Environmental proactivity stands as a fundamental part of these actions. The objective of this work is to understand who and why, companies include the environmental proactivity as an element of the company's strategy. This research has been divided into two separate but interconnected, methodological phases. The first step applied qualitative methods to describe a generic model environmental performance at the automotive industry, while the second step applied quantitative methods to reinforce previous hypothesis. The empirical application focuses on the Spanish automotive industry. The barriers and facilitators of the integration of environmental proactivity in business strategy as well as the benefits it provides to companies are identified.
\end{abstract}

Key words: automotive industry, environmental proactivity, sustainable development, strategy

* Author to whom all correspondence should be addressed: e-mail: maseo@omp.upv.es; Phone: +34-963877000 (\# 76844); Fax: +34963879779 (\# 79779) 


\section{Introduction}

Environmental proactivity, understood as a firm's tendency to initiate changes in its various strategic policies rather than to react to events (Aragón-Correa, 1998), offers a vision of progress that integrates immediate and longer term objectives as well as local and global action, and regards social, economic and environmental issues as inseparable and interdependent components of human progress (Porter and Van der Linde, 1995), understanding social development to be a social dilemma (Cordente-Rodríguez et al., 2010).

In broad terms, the concept of sustainable development is an attempt to combine growing concerns about a range of environmental issues with socio-economic issues (Ferrari et al., 2010; Herea, 2010). In this new context, it is essential to examine the extent to which the environmental factor is part of the business strategy of companies (Singh et al., 2008; Welford, 1995), how companies incorporate their environmental performance is an emerging competitive priority in manufacturing strategy (Segarra et al., 2011a).

Companies need to differentiate through sustainability as a strategic factor is becoming more and more evident, but there is still no scientific basis to carry out its measure. Consequently, it is necessary to analyze the environmental factor as a proactive aspect of company's management, as well as the determining factors encouraging a company to move towards environmental protection in what come to be called „corporate environmentalism” (Banerjee, 2002; Banerjee et al., 2003). Several authors have analyzed the integration of the environmental factor in business strategy (Da Silva et al., 2009; SegarraOña et al., 2011a). On a general level, the influence of factors such as social pressure (Vargas-Vargas et al., 2010), environmental legislation (Repetto et al., 1997; Telle and Larsson, 2007), competitive advantages and management's commitment to the company's environmental focus (Boyd and McClelland, 1999; Russo and Harrison, 2005 Hopwood et al., 2005) and the development of its strategies have been studied (Liu et al., 2010; Walker et al., 2008), and also aspects as companies' efficiency and environmental performance, concerning health, safety and environmental management system principles (Abbaspour et al., 2006).

Multiple studies have been performed on the application of environmental management tools; Abbaspour et al. (2006) studied the implementation of sustainable management systems in sports complexes, Russo and Harrison (2005) found that incentives could be a valuable tool for improving environmental performance and, then, environmental promotion could be an opportunity to shape an organization's redesign to be more proactive. McKeiver and Gadenne (2005) analyzed both, the external and internal factors affecting the implementation of an environmental management system and Brunnermeier and Cohen (2003) studied which were the determinants of environmental innovation in US manufacturing industries. Other authors studied how could competitive advantages be gained through environmental orientated activities (Ferguson and Toktay, 2006; Sharma and Vredenburg, 1998) or how firms performance could be improved (González-Benito and González-Benito, 2005; Melnyk, 2003).

Some studies have applied the theories developed so far to identify the factors affecting the environmental orientation adopted by companies. Extensive studies on business proactivity applied to specific sectors can be found. For example, on a Spanish level, Aragón-Correa et al. (2008) found that in the automotive repair sector, the economic performance of companies with more proactive practices was improved. In the work performed by Martín-Tapia (2009), the food industry was studied and a correlation between advanced environmental strategies and the export level of the SMEs was found. Some authors have shown that there is a correlation between environmental social responsibility and the economic performance of hotels (García and Armas, 2007), and a correlation between environmental orientation and economic performance was found in the tourism industry (Claver-Cortés et al., 2007; Molina-Azorín et al., 2009).

\section{Aims and structure of the article}

Currently, there is a need to analyze the actual inclusion of environmental proactivity in the global strategy of organizations as a differentiating element and hence, creator of competitive advantages, by analyzing the extent to which the environmental factor forms part of the business strategy. Taking into account the above, the overall aim of this work is to study the environmental factor as a proactive aspect of company management and identify the factors that help companies to move towards sustainable management; the specific objectives being the identification of the factors characterizing environmental performance, the classification of these companies based on this behavior, the assessment of the level of integration of environmental proactivity in the companies' strategy and the identification of the facilitators and difficulties encountered by companies with respect to their environmental management (Gavronski, 2007; Walker, 2008).

The study has been performed on the automotive Spanish industry. Studies characterizing the environmental orientation of the companies in the industry have been done before. Simpson et al. (2007) studied the automotive supply chain in Australia supporting the importance of asset-specific investments in the relationship between a customer's environmental performance requirements and their potential to improve the supplier's environmental 
responsibilities, Crotty and Smith (2006) analysed the U.K. automotive sector, Zhu et al. (2007) identifies internal and external drivers to implement green supply chain management systems at the that Chinese automobile companies, that has been studied from diverse perspectives in the last years (Darnall et al., 2008; Simpson et al., 2007; Walker, 2008). González-Torre et al. (2009) studied the Spanish automotive industry from a reverse logistic focus remarking the importance of external and internal barriers for implementing it.

On the other hand, trying to identify factors affecting the environmental orientation adopted by companies, some studies have been developed. In the consumer goods sector, factors such as the influence of external pressure forces, environmental orientation, corporate and marketing strategies, size, macro-sector and whether or not the company has a marketing department were found to have an influence on which environmental strategy is adopted (Buil-Carrasco, et al., 2005; Mitchell et al., 2010). González-Benito and González-Benito (2005) identified several environmental proactivity strategies in three industrial sectors, electricity, chemicals and furniture, noting the multidisciplinary nature of environmental proactivity. López-Gamero et al. (2009) quantitatively and qualitatively studied how environmental regulations affect companies differently depending on the sector they belong to, and found they had a greater effect on companies in sectors which are potentially more polluting such as the primary and secondary sectors, than on service sector companies.

The combination of the resource based theory, RBV (Penrose, 1959), with the adoption of environmental strategies has also been considered, through the development of an integrated framework for analyzing the relationship between environmental strategies and the development of the company's specific environmental capabilities (Da Silva et al., 2009; Sharma et al., 2007; Smith, 2010; Verbeke et al., 2006).

Though they may appear to be different, they all have points in common in that they analyze the strategic positioning in different intermediate states between the most reactive and most proactive point of view (Alvárez-Gil et al., 2001).

Although the studies performed to date are high quality and specialized works, there is not yet enough data which aids in identifying the particular aspects of environmental proactivity as size, type (national or multinational) and preeminence at the industry (automotive producer, first level supplier, etc.) with an influence on business competitiveness nor is there sufficient scientific basis for carrying out its measurement, even the needs that car manufacturers have to consider effects of environmental factors on their businesses (Segarra et al., 2011b). Our study points in this direction, and our main hypotheses are as follows:

H1: Proactive environmental orientation depends on the size of the company.
H2: The multinational nature of a company facilitates its proactive orientation.

\section{General overview of the automotive sector}

Spain is a country with a significant international influence in the automotive industry (González-Torre et al., 2009), being one of the main pillars for the Spanish economy, and in 2008, it generated approximately $9 \%$ of both direct and indirect jobs available to the labor force and accounted for 3.5\% of the GDP (Aláez et al., 2009).

The automotive sector in Spain includes vehicle manufacturing industry and the ancillary industry of automotive parts. The first of the subsector, the vehicle manufacturing industry is composed of a group of multinational companies, all of whose capital is foreign (Renault-Nissan, Volkswagen, General Motors, Daimler-Chrysler, PSA and Ford), which engage in the manufacturing of passenger and commercial vehicles. Spain is the 8th largest manufacturer of passenger and commercial vehicles worldwide, and the 3rd largest manufacturer in Europe, after Germany and France (ACEA, 2010).

There are a total of 18 factories in Spain, which have produced 2,541,644 vehicles (2008), of which approximately $80 \%$ were for export. The total employment includes 67,263 workers and has a total turnover of 38,421 million euro (ANFAC, 2009). The ancillary industry of automotive parts is composed of a large group of companies with a key role in the Spanish economy. This sector has a turnover of 29,970 million euro, of which approximately $60 \%$ are for export. In terms of employment its importance is greater, since it employs 208,766 individuals (ANFAC, 2009). Of every 5 employees in the automotive sector, 4 belong to the ancillary parts industry. As for the origin of the capital of the above mentioned companies, it is important to highlight that in 2008, the Spanish capital is responsible approximately for $50 \%$ of the turnover. The presence of Spanish capital is major in the medium and small companies. As for the large ones, $26 \%$ of the companies of more than 500 workers belong to Spanish capital.

\section{Material and methods}

This research has been divided into two separate but interconnected, methodological phases. The first step applied qualitative methods to describe a generic model environmental performance at the automotive industry, while the second step applied quantitative methods to reinforce previous hypothesis.

Part one of this study is based on research in the automotive industry and, considering that according to Kaplan (1986), if a theory is to be generated based on a theoretical framework and the key questions are what they are, as well as how the barriers and facilitators of environmental proactivity 
influence competitiveness, it is most appropriate to carry out studies of cases of explanatory type, classified as direct data collection (Stake, 1995). Five cases were studied according to Rouse and Daellenbach (1999).

To have high rigor level when using case studies as the methodological research, some considerations have to be taken into account, related to design aspects (identify clear research questions, selection, take advantage of pilot cases in order to help refine the design and the data collection plans), to data collection (provide detailed information with respect to the data collection methods, procedures, sampling strategies, number of interviews, and interviewees, use of an interview guide, instrument validation, effectively use tables to summarize information about the data collection process and triangulate data in order to increase internal validity of the findings and provide clear explanations on how the triangulation process is achieved) and data analysis (Dubé and Paré, 2003).

Following Flyvbjerg (2006), when the objective is to achieve the greatest possible amount of information on a given problem or phenomenon, atypical or extreme cases reveal more information, for that reason we studied the vehicles producer, Ford among the chosen firms and four of this company's vendors, which supply either services or subassemblies. The geographic location of all the companies is the same, all of them being located in the province of Valencia. Since the aim of this study is not to single out the companies and make their environmental management policy public, but rather to aid them in learning and identifying factors which are helpful to them or the difficulties they encounter, the companies have been numbered from one to five to preserve their anonymity.

\subsection{Part one: identifying case's studied proactive attitude}

A questionnaire to measure environmental integration (Segarra et al., 2009) was applied, used as a tool for guiding semi-structured interviews as casestudy method can certainly contribute to the cumulative development of knowledge (Flyvbjerg, 2006; Stake, 1995)

The results of the interviews conducted with the environmental heads of the companies studies were then analyzed, differentiating between the level of the manufacturers (according to industry criteria), and the type of company (national, multinational) and size. Findings were determinant since differences between companies belonging to the same industry were explained in order to characterize the company in terms of its level of environmental proactivity and to establish a system for measuring the integration of environmental proactivity in the company's business strategy.

Furthermore, the factors determining the proactive environmental orientation have been classified as internal aspects of the company (size, level of internationalization, position on the value change, attitude of the management as well as the motivation and strategic attitude of the company), external (sector and Geographic location) and as a determining factor, the pressure of the shareholders/owners (González-Benito and González Benito, 2005). Also, Aragón-Correa et al. (2008) and Paulraj (2011) followed the factors classification as external (legislation, clients, vendors, companies in the sector, financial entities, insurers, media, ecologists and/or citizens or nearby communities; and internal (management, partners and shareholders and/or employees).

On the other hand, since the interview is conducted personally by one of the researchers, an attempt is made to gather qualitative information not directly related to the specific questions included in the questionnaire by means of informal talks with employees of the company, identification of information/internal training, and examination of the company's products and manufacturing processes (Beveridge, 1951).

Since qualitative research is very helpful and its use is essential when one wishes to avoid errors of assessment and interpretation, information control has been included in the study in several ways: firstly, through prior contact with environmental experts and department heads or research groups, by including a qualitative phase prior to the design of the survey in order to extract information for the design of the response categories. Secondly, since it is the researcher who conducts the interview, is able to qualitatively guide the questions and advise on the response categories.

\subsection{Part two: empirical data confrontation}

This research adopted a three-step quantitative methodology. In line with Dubé and Pare (2003), well-known standardized statistical analysis methods, such as analysis of variance and regression analysis, have helped researchers confirm or reject hypotheses in quantitative research. Thus, a factorial analysis method was applied to reduce data variables. This technique allows us to obtain homogeneous correlated variable groups. Moreover, a linear regression model with previous factor analysis identification fitted with the data and, finally a correspondence analysis (Greenacre, 1984, Greenacre 1993) to measure the reciprocal averaging between the variables studied and the environment orientation of the company.

\subsection{The sample}

Companies analysed in the first part are located in the Valencian region, belonging to the automotive cluster (Miret-Pastor et al., 2011) while the sample of companies used for the quantitative analysis were located across Spain in order to cover a broader scenario. 
For the cases study, two large international companies (E1 and E5) three medium-sized companies were studied, one of which is multinational (E2) and two national (E3 and E4). All the companies have implemented environmental management systems based on the ISO 14001 standard, and at least one individual dedicated to environmental tasks, as well as a company, although one company has its own environmental management department. The fact that all companies surveyed have implemented an environmental management system based on ISO 14001 is not a differentiating factor between them, since environmental certification is required of all their vendors by automobile manufacturers. Therefore, other aspects must be identified to effectively characterize their environmental orientation.

For the quantitative analysis the data were collected from the PITEC database (Technological innovation panel), which consists of a statistical tool to monitor the technological innovation activities of Spanish companies. The database was built by the INE (Spanish national statistics institute) with the advice of academics and experts and includes a comprehensive list of Spanish companies which are characterised by the type of innovation (classified by the Oslo Manual, 2005) that they undertake, by industry (in line with the Spanish national activities classification, CNAE) or by geographical location and a total of 255 variables are analysed in each period. Affiliate level information is not available as data is taken from an anonymous macroeconomic survey.

Out of 11,686 firms that conform the whole 2008 database a total of 268 firms belong to the automotive industry.

Variables included in this study were selected according to theoretical statements. Net sales (NS) represents the total sales income in 2008, total goods investment (INVER) represents gross investment in tangible goods in 2008, size by number of employees (SZ) represents the number of full-time employees in the company during 2008, National market (MDONAC) indicates whether the companies operate on a national scale. This is a binary variable with $1=$ Yes and $0=$ No. E.U. market (MDOUE) indicates whether the companies operate on a European scale. This is a binary variable with $1=$ Yes and $0=$ No. The total investment in RandD activities at an internal level is represented by (GINTID) and at external level by (GEXTD). (PIDCA) represents the number of full-time employees who work on RandD activities. (PATNUM) number of national patents and (PATEPO) number of European patents were measured as the number of patents applied at European and Spanish level.

\section{Results analysis}

\subsection{Results from the qualitative analysis}

5.1.1. Identification of factors characterizing the companies' environmental performance

Based on qualitative case study on environmental proactivity at the automotive industry questions were classified and tangible and nontangible data obtained in the interviews were analyzed twofold. On one hand, the importance that companies give to specific actions was evaluated and, on the other hand, each company was assessed by means of the application of these measures. Results show that, on one hand and in order of importance, the environmental performance measures that companies take are: 1) To report internally information on the measures taken, 2) To quantify environmental costs and savings in internal budgets, 3) To apply energy saving measures, 4) To apply water saving measures, 5) To report information on the measures taken externally and 6) To use ecological arguments in their marketing campaigns.

On the other hand, it was found that the importance given by companies studied to the available environmental measures is mainly based in the orientation towards the use of ecological products and the manufacturing of recyclable products, as it was observed, and there was a clear tendency to eliminate the most polluting products as well as lines of work on inverse logistics aimed at the environment, consisting of attempting to recycle, repair, re-use, and reprocess components for competitive, economic and environmental reasons (Cordente-Rodríguez et al., 2010; Gruia et al., 2010).

All the companies have different binds for separating waste and all but one (C4) implements measures to improve training in environmental issues. With regard to external environmental orientation, on the whole companies externally reported information on activities carried out $56 \%$ of the time. Ecological arguments are used in marketing campaigns $44 \%$ of the time. A higher incidence of issues relating to internal environmental orientation were found, since on a whole, the companies internally report information on measures taken $88 \%$ of the time, and quantify environmental costs and savings in internal budgets $84 \%$ of the time. A group of companies (1,2 and 5) was found to both internally and externally report the environmental management measures taken. One company (3) quantifies and reports its measures internally but not externally and the other neither quantifies nor reports these measures either internally or externally.

It was also noted that the influence of partners, shareholders and management on decisions relating to the environment as well as the influence of the government is important. However, the influence of employees and vendors on decisions taken in relation to the environment was not considered to be an aspect to be taken into account.

\subsubsection{Identification of obstacles to proactive orientation}

The main obstacles faced by companies when attempting to adopt a more proactive environmental 
strategy are lack of financial support, lack of institutional support, lack of technical solutions, lack of qualified human resources and lack of information on tools (See Fig. 1).

A higher score shows that the company sees "great obstacles" and a low score shows that the obstacles perceived are lower.

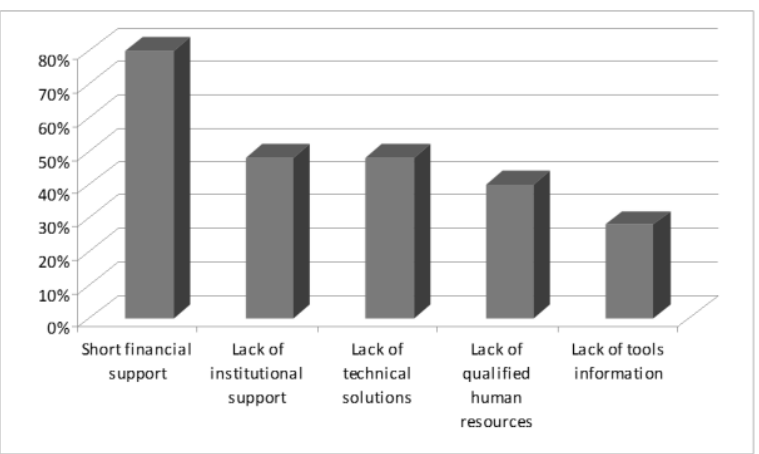

Fig. 1. Obstacles to proactivity

\subsubsection{Identification of the benefits of environmental actions \\ Companies studied identify significant} benefits arising from the implementation of proactive environmental management actions, including the improvement of its image, competitive position and the long-term benefits achievement, although positive aspects were not noted in the short-term. Fig. 2 shows the benefits as well as their weighted weight. On the other hand, the benefits of research and development on new products and more ecological processes was successfully identified, noteworthy being the improvement of the quality of the products and process, the possibility of entering new markets, the possibility of being market leader and the increase in market share
The environmental management systems are seen as being applicable in the companies studied in $100 \%$ of the cases, also considering that they contribute to improved control and decision making (80\%).

In the majority of cases they are considered to be a necessary investment ( $72 \%$ of the time) and it is not considered that they should be implemented only if compulsory $(36 \%)$ or only in large companies $(16 \%)$.

\subsection{Results from the quantitative analysis}

An exploratory factor analysis was performed on all ten independent variables, using factor analysis (Varimax method) in an attempt to understand the factor structure and the corresponding measurement quality. The solution shows four factors which account for $80.83 \%$ of the variance and significance 0.000 , namely size, open market orientation, formal innovative activity and total innovation investment (Table 1 shows the factor analysis results).

Considering the aggregation of the variables derived from the previous factor analysis, a multinomial regression was applied, as can be seen in Table 2. Due to the lack of some data, 39 companies were discarded, so the final subpopulation remained in 229 Spanish companies belonging to the automotive industry.

The chi-square statistic is the difference in -2 log-likelihoods between the final model and a reduced model. The reduced model is formed by omitting an effect from the final model. The null hypothesis is that all parameters of that effect are 0 .

The overall interpretation of the statistics outcomes indicates that the model fits significatively (0.002) and that Factor 1 (Size) and Factor 3 (export orientation) have a consistent weight in it.

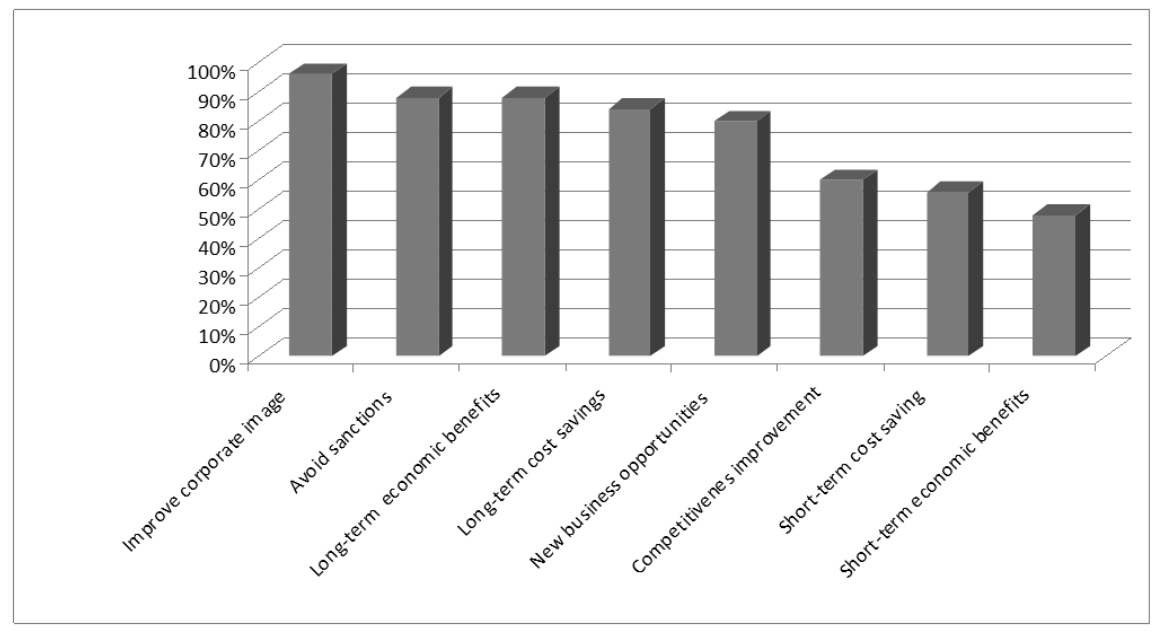

Fig. 2. Benefits arising from environmental proactivity 
Table 1. Summary of exploratory factor analysis results Rotated Component Matrix ${ }^{\mathrm{a}}$

\begin{tabular}{|l|c|c|c|c|}
\hline \multirow{2}{*}{} & \multicolumn{3}{|c|}{ Components } \\
\cline { 2 - 5 } & Size & $\begin{array}{c}\text { Formal } \\
\text { innovative activity }\end{array}$ & $\begin{array}{c}\text { Export } \\
\text { orientation }\end{array}$ & $\begin{array}{c}\text { Total innovation } \\
\text { investment }\end{array}$ \\
\hline Net sales (NS) & 0.980 & & & \\
\hline Total goods investment, (INVER) & 0.918 & & & \\
\hline Size by number of employees (SZ) & 0.957 & & 0.777 & \\
\hline National market (MDONAC) & & & 0.817 & \\
\hline E.U. market (MDOUE) & & & & -0.701 \\
\hline Internal RandD investment (GINTID) & & & & 0.838 \\
\hline External RandD investment (GEXTID) & & & & \\
\hline Number of RandD employees (PIDCA) & 0.771 & & & \\
\hline Number of national patents (PATOEPM) & & 0.870 & & \\
\hline Number of European patents (PATEPO) & & & & \\
\hline$\%$ of variance & $33.85 \%$ & $18.97 \%$ & $15.94 \%$ & $12.075 \%$ \\
\hline
\end{tabular}

a. Rotation converged in 4 iterations. * Principal Component analysis. Varimax with Kaiser Normalisation. $72.70 \%$ variance explained -KMO 659- Sig .000

The dependent variable of the model is the so called EFECTO 8 in the PITEC database (ENV-IMP in our research), which measures how essential it is for innovating firms to improve their environmental impact.

Correspondence analysis represents the rows and columns of a two-way contingency table as points in Euclidean spaces (Cox and Cox, 2008), used to reduce the dimensionality of the categorical data (Vyas and Kumaranayake, 2006).

Table 3 shows the results of each of the profiles of the companies studied. As you can see most of the companies or are $100 \%$ Spanish private capital (type 2) and companies with more than 50\%, foreign capital (type 5). An analysis of correspondence with minimal distance between the two variables has been made (Table 4 ), concluding that companies in group 5, 4 and 3 answered mostly 1 or 2 on the target 11 that is, medium and high environmental proactivity, while companies belonging to group 2 (only 100\% Spanish capital firms) tend to answer 4 or 3 (no interest).

As we can see in Fig. 3, distances between circles of classes and the responses show a greater tendency or affinity to such responses. The closer a circle of class and more likely a response indicates that response and vice versa. Class 1 (public company) could be ruled out since there is only one case and therefore a single response (this is far removed from the set of responses). In Fig. 3 the distances between each group and each response are represented. Minimal distances have been coloured.

Table 2. Multinomial regression likelihood ratio tests

\begin{tabular}{|l|c|c|c|c|c|c|}
\hline \multirow{2}{*}{ Effect } & \multicolumn{3}{|c|}{ Model fitting criteria } & \multicolumn{3}{|c|}{ Likelihood ratio tests } \\
\cline { 2 - 7 } & $\begin{array}{c}\text { AIC of reduced } \\
\text { model }\end{array}$ & $\begin{array}{c}\text { BIC of reduced } \\
\text { model }\end{array}$ & $\begin{array}{c}\text {-2 log likelihood of } \\
\text { reduced model }\end{array}$ & $\begin{array}{c}\text { Chi- } \\
\text { square }\end{array}$ & sf & sig. \\
\hline Size & 641.368 & 682.573 & 617.368 & 16.845 & 3 & $0.001 *$ \\
\hline $\begin{array}{l}\text { Formal } \\
\text { innovative } \\
\text { activity }\end{array}$ & 626.797 & 668.001 & 602.797 & 2.274 & 3 & 0.518 \\
\hline $\begin{array}{l}\text { Export } \\
\text { orientation }\end{array}$ & 635.644 & 676.849 & 611.644 & 11.121 & 3 & $0.011 *$ \\
\hline $\begin{array}{l}\text { Total innovation } \\
\text { investment }\end{array}$ & 627.724 & 668.929 & 603.724 & 3.201 & 3 & 0.362 \\
\hline
\end{tabular}

*The chi-square statistic is the difference in -2 log-likelihoods between the final model and a reduced model. The reduced model is formed by omitting an effect from the final model. The null hypothesis is that all parameters of that effect are 0. 
Table 3. Correspondence table

\begin{tabular}{|c|c|c|c|c|c|}
\hline \multirow[b]{2}{*}{ COMPANY TYPE (“CLASEN”VARIABLE) } & \multicolumn{5}{|c|}{ Env-Imp (eco-innovative orientation) } \\
\hline & High & Medium & Low & $\begin{array}{c}\text { Not } \\
\text { considered }\end{array}$ & $\begin{array}{c}\text { Active } \\
\text { margin }\end{array}$ \\
\hline 1. Public companies & 1 & 0 & 1 & 0 & 2 \\
\hline 2. Private companies & 29 & 35 & 29 & 49 & 142 \\
\hline 3. Private companies with less than $10 \%$ of foreign capital & 1 & 1 & 0 & 0 & 2 \\
\hline 4. Private companies with $10 \%<$ foreign capital $<50 \%$ & 2 & 4 & 1 & 1 & 8 \\
\hline 5. Private companies with more than $50 \%$ of foreign capital & 19 & 28 & 16 & 12 & 75 \\
\hline 6. Research associations & 0 & 0 & 0 & 0 & 0 \\
\hline Active margin & 52 & 68 & 47 & 62 & 229 \\
\hline
\end{tabular}

Table 4. Minimal distances between type of company and proactivity orientation

\begin{tabular}{|c|c|c|c|c|c|}
\hline & $\begin{array}{c}\text { High } \\
\text { environmental } \\
\text { proactivity when } \\
\text { innovating }\end{array}$ & $\begin{array}{c}\text { Medium } \\
\text { environmental } \\
\text { proactivity when } \\
\text { innovating }\end{array}$ & $\begin{array}{c}\text { Low environmental } \\
\text { proactivity when } \\
\text { innovating }\end{array}$ & $\begin{array}{c}\text { No } \\
\text { environmental } \\
\text { proactivity } \\
\text { when } \\
\text { innovating } \\
\end{array}$ & $\begin{array}{l}\text { Minimal } \\
\text { distance }\end{array}$ \\
\hline 1. Publics & 3.04041116 & 3.66928835 & 2.88234366 & 3.71692306 & $\begin{array}{c}2.8823436 \\
6 \\
\end{array}$ \\
\hline 2. Private national & 0.72648331 & 0.9089824 & 0.59360677 & 0.40264749 & $\begin{array}{c}0.4026474 \\
9\end{array}$ \\
\hline $\begin{array}{l}\text { 3. Private less than } 10 \% \\
\text { of foreign capital }\end{array}$ & 1.52143748 & 1.18457798 & 1.92850953 & 2.40094002 & $\begin{array}{c}1.1845779 \\
8 \\
\end{array}$ \\
\hline $\begin{array}{l}\text { 4. Private } 10 \%<\text { foreign } \\
\text { capital<50\% }\end{array}$ & 1.14246444 & 0.54729882 & 1.51916095 & 1.72313784 & $\begin{array}{c}0.5472988 \\
2\end{array}$ \\
\hline $\begin{array}{l}\text { 5. Private more than } \\
50 \% \text { of foreign capital }\end{array}$ & 0.33308407 & 0.40927497 & 0.73600272 & 1.28860933 & $\begin{array}{c}0.3330840 \\
7\end{array}$ \\
\hline
\end{tabular}






Fig. 3. Correspondence analysis. Minimal distance

Therefore, the general trend is that the more foreign capital in the company are the answers to environmental proactivity are higher than in $100 \%$ Spanish capital firms that tend to show little or no interest in environmental proactivity.

\section{Results and discussion}

The objective of this work was to identify the integration of the environmental actions into the managerial strategy of firms. In general terms it could be argued that firms are optimistic when directly questioned about the inclusion of environmental actions. However, when specifically asked how such inclusion materializes, their actions are not as optimistic.

The analysis of the data shows that multinational companies could be classified as proactive, with a high involvement of the partners, management, and shareholders, whereas the national companies could be classified as reactive, considering that the involvement of partners, management and shareholders is either medium or indifferent. The actual inclusion of environmental proactivity in the overall strategy of the organizations, as a differentiator, and therefore, creator of competitive advantages, was analyzed. Interesting conclusions were obtained such as the fact that this process was considered to be compatible with industrial development (76\%) of the time, although in a high percentage of cases, the companies feel pressured by legislation $(60 \%)$ and the cost of the resources allocated is high $(60 \%)$. None of the companies studies consider it to be an aim which has been fully achieved and $50 \%$ of the companies sampled considered this to be utopian.

The barriers to and facilitators of the implementation of proactive environmental actions have been identified, which enables policy makers to act directly on the sector studied. Additionally, it is interesting to note that the companies take action in this field in order to improve their image, obtain future benefits and largely due to changes in legislation. However, in general they quantify environmental costs and savings.

The main lines of action taken by the company consist in water and energy saving measures. Also noteworthy is that ecological arguments are scarcely used (44\%) in marketing campaigns.

The cases studied were reduced specifically to the automobile sector in order to be able to articulate vertical industrial policies that contribute to the fostering of measures to promote environmental proactivity.

On the other hand, an exploratory factor analysis was performed reducing initial variables in four factors which account for $80.83 \%$ of the variance and significance 0.000 , representing size, open market orientation, formal innovative activity and total innovation investment. Therefore, a multinomial regression was applied showing that the main aspects that determine the environmental orientation at the automotive Spanish industry are size and export orientation. Accordingly, a complementary correspondence analysis was applied confirming the previous results, the minimal Euclidean distance found that the more foreign capital in the company are, the attitude towards environmental is more responsible and that companies without external influence (100\% Spanish capital), tend to show little or no interest in environmental proactivity.

The methodology applied in this study is shown to be of interest and useful in that it enables the companies studied to be classified according to their environmental proactivity and to objectively measure the importance of the actions taken for the company. The analysis of the environmental factor as a proactive aspect of company management is a complex phenomenon involving a number of 
determinants. In this regard, multivariate statistical analyses play a significant role in the adoption of environmental decisions enabling, on one hand, the company (D'Amico et al., 2010) and, on the other hand, policy makers (Faber and Frenken, 2009, Rivas and Magadán, 2010, Burciu et al., 2010) to move towards environmental protection. Thus, modeling is one of the main multivariate statistical techniques for assessing environmental aspects and which ones have more influence when it comes to differentiating a company by means of environmental sustainability, so the study will continue in that line, extending the study to other industrial sectors for the purpose of drawing up a Spanish map of environmental proactivity, and replicate the results in studies including other neighboring countries.

\section{Conclusions}

The environmental proactivity of the automobile industry located in the Valencian region was studied. The barriers and facilitators that companies consider to be important for including proactive environmental actions in their business strategies were identified. With respect to the hypotheses made in the study, it was observed in both, quantitative and qualitative analysis, that multinational and larger companies have a clearer environmental orientation. Therefore, it can be concluded that H1 (small size is a barrier to the company's environmental proactivity) and $\mathrm{H} 2$ (the multinational nature of the company facilitates its proactive orientation) are correct.

\section{Acknowledgements}

The authors acknowledge the financial aid received from the Spanish Ministry of Science and Innovation through the research project reference no. EC02008-05895-C02-01/ECON. Also the Technical University of Valencia for its research funding to the project "Innovative impact on the companies environmental performance: identifying moderating factors" (PAID-06-2011) leaded by M. Segarra and for supporting the sabbatical research 2011-2012 course of M. Segarra-Oña.

\section{References}

Abbaspour M., Karbassi A.R., Khadivi S., (2006), Implementation of green management concepts in sport complexes, International Journal of Environmental Research, 3, 213-219.

ACEA, (2010), EU Economic report, European Automobile Manufacturers Association, Brussels, 193-199.

Aláez R., Bilbao J., Camino V., Longás J.C., (2009), Thoughts on the crisis in the Spanish automotive industry and its perspectives Spanish Business Information, ICE: Journal of Economics, Published in Spanish (Reflexiones sobre la crisis de la industria española del automóvil y sus perspectivas, Información Comercial Española, ICE: Revista de economía), 850, 41-56.

ANFAC, (2009), Memoria de 2008, Spanish Vehicles Manufacters Association, Madrid.

Aragón-Correa J.A., (1998), Strategic proactivity and firm approach to the natural environment, Academy of Management Journal, 41, 556-568.

Aragón-Correa J.A., Hurtado-Torres N., Sharma S., García-Morales V.J., (2008), Environmental strategy and performance in small firms: A resource-based perspective, Journal of Environmental Management, 86, 88-103.

Banerjee S.B., (2002), Corporate environmentalism. The construct and its measurement, Journal of Business Research, 55, 177-191.

Banerjee S.B., Iyer, S.Y., Kashyap R.K., (2003), Corporate environmentalism. Antecedents and influence of industry type, Journal of Marketing, 67, 106-122.

Beveridge W.I.B., (1951), The art of scientific investigation, William Heinemann, London.

Boyd G.A., McClelland J.D., (1999), The impact of environmental constraints on productivity improvement in integrated paper plants, Journal of Environmental Economics and Management, 38, 121-142.

Brunnermeier S.B., Cohen M.A., (2003), Determinants of environmental innovation in US manufacturing industries, Journal of Environmental Economics and Management, 45, 278-293.

Burciu A., Bostan I., Condrea P., Grosu V., (2010), Financing the environmental policies in the Communitarian space, Environmental Engineering and Management Journal, 9, 1179-1185.

Claver-Cortés E., López M.D., Molina J.F., Tarí J.J., (2007), Environmental management and firm performance: A case study, Journal of Environmental Management, 84, 606-619.

Cordente-Rodríguez M., Mondéjar-Jiménez J.A., Meseguer-Santamaría. M., Mondéjar-Jiménez J., Vargas-Vargas M., (2010), Environmental behavior and selective waste management in Spanish housing, Environmental Engineering and Management Journal, 9, 1165-1171.

Cox M.A., Cox T.F., (2008), Multidimensional Scaling, In: Handbook of Data Visualization, Chen C.-h., Hardle W., Unwin A. (Eds), Springer Handbooks of Computational Statistics, Springer, 315-347.

D’Amico F., Buleandra M.M., Buleandra M., D’Amico G., Tanase J., (2010), Industrial district revitalization through sustainable development policies, Environmental Engineering and Management Journal, 9, 281- 291.

Dubé L., Paré G., (2003), Rigor in IS Positivist Case Research, MIS Quarterly, 27, 597-635.

Faber A., Frenken K., (2009), Evolutionary methodologies for analyzing environmental innovations and the implications for environmental policy, Technological Forecasting and Social Change, 76, 462-470.

Ferguson M.E., Toktay L.B., (2006), The effect of competition on recovery strategies, Production and Operations Management, 15, 351-368. 
Ferrari G., Mondéjar-Jiménez J., Vargas-Vargas M., (2010), Environmental sustainable management of small rural tourist enterprises, International Journal of Environmental Research, 4, 407-414

Flyvbjerg B., (2006), Five misunderstandings about case-study research, Qualitative Inquiry, 12, 219-245.

García F.J., Arma Y., (2007), Relation between social-environmental responsibility and performance in hotel firms, Hospitality Management, 26, 824-839.

González Benito J., González Benito O., (2005), Environmental proactivity and business performance: an empirical analysis, Omega Internacional. Journal of Management Science, 33, 1-15.

González-Torre P., Álvarez M., Sarkis J., Adenso-Díaz B., (2009), Barriers to the implementation of environmentally oriented reverse logistics: Evidence from the automotive industry sector, British Journal of Management, 21, 889-904.

Greenacre M.J., (1984), Theory and Applications of Correspondence Analysis, Academic Press, London.

Greenacre M.J., (1993), Correspondence Analysis in Practice. Academic Press, London.

Gruia R., Tane N., Marculescu A., Padureanu V., (2010), Study on the process of emergetic sustainability applied in the management of "environmental-economy" complex systems, Environmental Engineering and Management Journal, 9, 1647-1650.

Herea V., (2010), Policy and strategy for improving sustainable social development programmes. Environmental Engineering and Management Journal, 9, 861-868.

Hopwood B., Mellor M., O’Brien G., (2005), Sustainable development: mapping different approaches, Sustainable Development, 13, 38-52.

Kaplan R.S., (1986), The role for empirical research in management accounting, Accounting, Organizations and Society, 11, 429-452.

Liu X., Liu B., Shishime T., Yu Q., Bi J., Fujitsuka T., (2010), An empirical study on the driving mechanism of proactive corporate environmental management in China, Journal of Environmental Management, 91, 17071717.

López-Gamero M.D., Claver-Cortés E., Molina-Azorín J.F., (2009), Evaluating environmental regulation in Spain using process control and preventive techniques, European Journal of Operational Research, 195, 497-518.

McKeiver C., Gadenne D., (2005), Environmental management systems in small and medium businesses, International Small Business Journal, 23, 513-537.

Melnyk S.A., Sroufe R.P., Calantone R., (2003), Assessing the impact of environmental management systems on corporate and environmental performance, Journal of Operations Management, 21, 329-351.

Miret-Pastor L., Segarra-Oña M., Peiró-Signes A. (2011), Identification of service sectors and high technology in Valencia: a new cluster mapping?,Regional Studies Journal (In Spanish, Revista de estudios regionales), 90, 71 96.

Mitchell R., Com M.A., Wooliscroft B., Higham J., (2010), Sustainable market orientation: a new approach to managing marketing strategy, Journal of Macromarketing, 30, 160-170.

Molina-Azorín J.F., Claver-Cortés E., Pereira-Moliner J., Tarí J.J., (2009), Environmental practices and firm performance: an empirical analysis in the Spanish hotel industry, Journal of Cleaner Production, 17, 516-524.

Paulraj A., (2011), Understanding the relationships between internal resources and capabilities, sustainable supply management and organizational sustainability, Journal of Supply Chain Management, 47, 19-37.

Penrose E.T., (1959), The growth theory of the firm, Wiley, New York.

Porter M.E., Van der Linde C., (1995), Toward a new conception of the environment competitiveness relationship, Journal of Economic Perspectives, 9, 97-118.

Repetto R., Rothman D., Faeth P., Austin D., (1997), Has environmental protection really reduced productivity growth, Challenge, 41, 46-57.

Rivas J., Magadán M., (2010), Less green taxes and more control over pollutant industries: a theoretical proposal, Environmental Engineering and Management Journal, 9, 1173-1177.

Rouse M.J., Daellenbach U.S., (1999), Rethinking research methods for the resource-based perspective: isolating sources of sustainable competitive advantage, Strategic Management Journal, 20, 487-494.

Russo M.V., Harrison N.S., (2005), Organizational design and environmental performance: clues from the electronics industry, Academy of Management Journal, 48, 582-593.

Segarra-Oña M., Peiró-Signes A., Albors-Garrigós J., Miret-Pastor L., (2011a), impact of innovative practices in environmentally focused firms: moderating factors, International Journal of Environmental Research, 5, 425434.

Segarra-Oña M., Carrascosa-López C., Segura B., (2011b), Do companies know which are the barriers and facilitators that enable proactive environmental orientation of the industry? An empirical study of a low tech industry, Information Technologies in Environmental Engineering Environmental Science and Engineering, 3, 373-388.

Sharma S., Vredenburg H., (1998), Proactive corporate environmental strategy and the development of competitively valuable organisational capabilities, Strategic Management Journal, 19, 729-753.

Sharma S., Aragón-Correa J.A., Rueda-Manzanares A., (2007), The contingent influence of organizational capabilities on proactive environmental strategy in the service sector: an analysis of North American and European ski resorts, Canadian Journal of Administrative Sciences, 24, 268-283.

Singh R.K., Murty H.R., Gupta S.K., Dikshit A.K., (2008), Development and implementation of environmental strategies for steel industry, International Journal of Environmental Technology and Management, 8, 69-86.

Simpson D., Power D., Samson D., (2007), Greening the automotive supply chain: a relationship perspective, International Journal of Operations and Product Management, 27, 28-48. 
Smith A.D., (2010), Growth of corporate social responsibility as a sustainable business strategy in difficult financial times, International Journal of Sustainable Economy, 2, 59-79.

Stake R.E., (1995), The art of case study research, Thousand Oaks, CA. Sage.

Telle K., Larsson J., (2007), Do environmental regulations hamper productivity growth? How accounting for improvements of plants' environmental performance can change the conclusion, Ecological Economics, 61, 438445.

Vargas-Vargas M., Meseguer-Santamaría M.L., Mondéjar - Jiménez J., Mondéjar-Jiménez J.A., (2010), Environmental protection expenditure for companies: a Spanish regional analysis, International Journal of Environmental Research, 4, 373-378

Verbeke A., Bowen F., Sellers M., (2006), Corporate environmental strategy: extending the natural resource-based view of the firm, Academy of Management Best Paper.

Vyas S., Kumaranayake L., (2006), Constructing socio-economic status indices: how to use principal components analysis, Health Policy and Planning, 21, 459-468.

Walker H., Di Sisto L., McBain D., (2008), Drivers and barriers to environmental supply chain management practices: lessons from the public and private sectors, Journal of Purchasing and Supply Management, 14, 6985 .

Welford R., (1995), Environmental Strategy and Sustainable Development, Routledge, London.

Zhu Q., Sarkis J., Lai K., (2007), Green supply chain management: pressures, practices and performance within the Chinese automobile industry, Journal of Cleaner Production, 15, 1041-1052. 
CAPÍtulo 5

ENVIRONMENTAL PROACTIVITY APPLIED TO

MANUFACTURING INDUSTRIES. IS IT VALUABLE? 


\title{
Environmental proactivity in manufacturing industries: Is it valuable?
}

\author{
Conrado Carrascosa-López, Universidad Politécnica de Valencia, Spain \\ Maríadel Val Segarra-Oña, Universidad Politécnica de Valencia, Spain \\ Angel Peiró-Signes, Universidad Politécnica de Valencia, Spain \\ Baldomero Segura-García-del-Rio, Universidad Politécnica de Valencia, Spain
}

\begin{abstract}
The purpose of this paper is to study the concept of environmental proactivity and its application to manufacturing industries. The literature on environmental proactivity and its application to different types of industries is reviewed. This paper examines the latest trends in the field and verifies their practical applicability and usefulness for companies. Increasing companies' competitiveness is key to their survival; interestingly, environmental proactivity can improve companies' productivity, and hence their competitiveness. The concept of environmental proactivity is often viewed with suspicion by manufacturing firms; in this work, a positive view of the concept of environmental proactivity is presented. This paper includes case studies of the application of environmental proactivity to three industrial sectors as well as a quantitative study to verify the results. The paper's conclusion is that the adoption of a proactive environmental approach provides benefits to companies in terms of image enhancement, cost savings, and new business opportunities, all of which contribute to the sustainable growth of companies.
\end{abstract}

Key words: environmental proactivity, sustainability, productivity, competitiveness

\section{Introduction.}

Interest in environmental care has increased across many fields in recent years (Vargas-Vargas et al., 2010). Global demand for low-environmental-impact and high-energy-efficiency products is increasing(Porter, Van der Linde, 1995).Throughout history, the industrial sector has been responsible for large-scale environmental degradation; however, industry's negative impact on the environment has decreased because of the growth of environmental awareness and the implementation of legislative changes to control industry's environmental impact (Fairchild, 2008).

Environmental proactivity is defined as the voluntary implementation of practices and initiatives aimed at improving companies' environmental performance (Gonzalez-Benito, Gonzalez-Benito, 2006). Determinants of environmental proactivity can be classified as internal or external to the company. Internal factors that can influence a company's environmental proactivity include the size of the company, support and commitment level of management, and whether the company is part of a larger corporation. External factors bearing on environmental proactivity include industrial sector (each sector has different pollution potential and it is controlled by public administrators in different ways) and location(environmental legislation and social pressure depend on where a company is located) (GonzálezBenito, González-Benito, 2006).Stakeholder commitment is considered essential for the development of proactive environmental strategies (González-Benito, González-Benito, 2010). Aragón-Correa et al.(2008) study small and medium enterprises (SMEs)and conclude that large company size aids the adoption of environmentally proactive policies; however, Aragón-Correa et al. also note that small company size does not completely prevent a business from adopting proactive environmental strategies. The relationship between pressure from stakeholders and proactive environmental practices varies by firm size. Small firms are more sensitive to these pressures and are more motivated to improve environmental performance (Darnall et al., 2010). However, not all companies respond well to internal pressure to increase environmental proactivity. Gadenne et al.(2009) note that even among companies with managers who have environmentally friendly attitudes, some still have poor environmental practices. 
It is necessary to look beneath the surface of companies, considering their fundamental absorptive capacities (Delmas et al., 2011) to identify those that are capable of adopting sustainable strategies successfully. Environmentally positive attitudes are not always linked with decisions that improve environmental performance; this is why empirical studies are recommended (Gadenne et al., 2009). An empirical approach is necessary in order to compare the effects of factors affecting environmental performance and to identify what influences each of them. (González-Benito, GonzálezBenito, 2006, Aragón-Correa, Sharma, 2003).

Several research papers describe benefits obtained by increasing environmental proactivity. For example, Aragón-Correa (1998) defines the positive impact of environmental proactivity in terms of the competitive advantages it affords to companies. There are situations where proactive behavior produces benefits for both the environment and companies (King, Lenox, 2001).A current research trend specifies and analyzes each benefit afforded to companies by increased environmental proactivity, such as corporate image improvement (Buysse and Verbeke, 2003). González-Benito's paper(2005) reveals that some aspects of environmental proactivity lead to positive effects in both company performance and marketing. In the research of Gadenne et al.(2009), more benefits conferred to companies by environmental proactivity are listed, including waste reduction, cost savings, increased customer satisfaction, product improvements, and public relations benefits. More recent research adds that environmental proactivity aids internationalization processes (Martín-Tapia et al., 2010), and even leads to improvements in companies' financial resources (Clarkson et al., 2011). Other researchers explore the link between environmentally friendly management techniques and value creation. For example, a case study verifies that certification under ISO 14001 (the International Organization for Standardization's environmental management standard)leads to company changes that may be transformed into benefits (Rondinelli, Vastag, 2000).Melnyk et al. (2003) demonstrate in a larger study of the US industrial sector that ISO 14001 certification brings real benefits. Darnall et al. (2008) find, in a sample of industrial companies in Canada, Germany, Hungary, and the United States, that implementing environmental management systems confers empirical benefits and creates potential business value for companies. In Spain, Segarra et al. (2011a) reveal the same positive relationship in the food industry. Rivas and Magadán(2010) propose a theoretical framework under which the Spanish government could reduce taxes on green companies and increase control over industries that pollute the most.

The most common method of studying corporate environmental proactivity is through quantitative studies based on surveys or interviews (Aragón-Correa, 1998, King, Lenox,2001;Menlyk,2003;Buysse y Verbeke,2003; González-Benito, GonzálezBenito,2005;Butler,2008;Darnall et al.,2008; Murillo-Luna et al.,2008;Darnall et al.,2010; Martín-Tápia et al.,2010; Haddock-Fraser, Tourell, 2010;Delmas et al.,2011; Clarkson et al., 2011; Segarra,2011a). Statistical studies confirm correlations among different aspects, but provide no evidence on causality (González-Benito, González-Benito, 2010).Some case studies have been conducted, although the sample sizes for these are smaller than those in statistical studies(Rondinelli, Vastag, 2000; Gadenne et al.,2009). Case studies can provide a better understanding of the true effects of environmental proactivity, and may prove whether it can provide real benefits.

Some authors criticize an excessively positive view of environmental proactivity; to a certain extent, they challenge the hypothesis that "it pays to be green". For instance, King and Lenox (2001) argue that research linking improved environmental performance with improved financial performance often lacks enough longitudinal information to verify this relationship. It is difficult to confirm the value of "being green in a sector" versus "being in a green sector."Therefore, the most important question in this field is, "When does it pay to be green?"The relationship between having a proactive strategy towards the environment and gaining a competitive advantage may not always be positive; it depends on the characteristics of the business environment, such as uncertainty and complexity, among others (AragónCorrea, Sharma, 2003). It has not always been possible to find evidence that environmental proactivity ensures greater profitability, at least in the short term (González-Benito, González-Benito, 2005). The first step in answering the question, "When does it pay to be green?" is to classify environmental investments according to their potential to yield competitive advantages. Orsato(2006) identifies four types of environmental strategies and indicates which competitive advantages may be obtained from each.

Some companies facilitate environmentally proactive strategies; however, in some companies, obstacles can stand in the way of adoption (Aragón-Correa, Sharma, 2003). The difficulties faced by companies who want to adopt more proactive environmental policies have not been well studied. Lack of financial resources is one of the major barriers hindering the development of proactive environmental practices (Gadenne et al., 2009). 


\section{Objectives and methodology}

This study's main objective is to perform an in-depth analysis of industry's environmental proactivity in the Valencian Community region of Spain. A rigorous study of industry's internal motivating factors with respect to environmental proactivity requires controlling for external factors, including environmental legislation, industrial sector, and location. Environmental legislation in Spain is not uniform throughout the country; part of the responsibility for environmental legislation lies with the governments of autonomous communities. Therefore, this study takes place solely within the Valencian Community, a geographic area with uniform environmental laws.

This research is divided into two independent but interconnected phases. In the first phase of the study, three empirical case studies are performed, one on each of the three major industrial sectors of the region. In the second phase of the study, a quantitative analysis is performed in order to verify and reinforce the first two hypotheses tested in the case studies. The analysis method used in this study allows comparison and contrast between information obtained from case studies and information obtained via quantitative analysis.

\section{Three case studies: The most important industrial sectors of the Valencian Community}

Case studies were conducted on the three most important sectors in the Valencian Community's economy in terms of export volume: the automotive sector, food industry, and tile industry. In 2010, the automotive sector produced $17 \%$ of the region's total export volume, the food industry produced $14 \%$, and the tile industry produced 9\% (IVEX, 2011).

The three case studies had the same structure. The first objective was to identify facilitators of environmental proactivity; company characteristics that help to develop proactive environmental performance were identified, such as company size, internationalization, and direct involvement of management. The second objective was to identify the obstacles inhibiting a company's adoption of an environmentally proactive approach. The third objective was to identify the benefits a company can expect after the adoption of a proactive environmental policy. Heterogeneous samples of firms were selected after appointments were made with company environmental officers. The company environmental officers were asked to complete verbal surveys that included Likert-scale questions and items designed to bear on each of the three hypotheses. The visits were conducted in person by a researcher, who made observations directly and indirectly. The data were analyzed in order to derive conclusions based on the following three hypotheses:

H1: Large company size facilitates environmental proactivity, and small size is a barrier to it.

H2: International competition facilitates environmental proactivity.

H3: Direct involvement of management is essential to facilitate environmental proactivity.

\subsection{Automotive sector case study}

A sample of five enterprises in the automotive sector was chosen, of which two were large multinational companies and three were SMEs. One SME was a multinational, and the remaining two conducted their activities only in Spain. Among the sample, all companies were ISO 14001 certified.

All three hypotheses were supported by the results of this case study, because the most proactive companies were multinational, large, and their management teams were highly involved with environmental issues.

The main obstacles to environmental proactivity faced by these companies were a lack of financial and institutional support. The main benefits expected by the companies after becoming more environmentally proactive were corporate image improvement, avoidance of punitive economic sanctions, and long-term economic benefits (Segarra et al., 2011a).

\subsection{Food industry case study}

A sample of 18 companies in the food industry was chosen, of which $38 \%$ were large and $62 \%$ were SMEs. Twenty-eight percent of the companies were multinational, and the remaining $72 \%$ conducted their activities only in Spain. Among the sample, 55\% of the companies were ISO 14001 certified.

$\mathrm{H} 2$ and $\mathrm{H} 3$ were supported by the results of this case study.H1 was only partially supported by the results of the case study: it was observed that large firms generally have better environmental performance than SMEs, but one SME had excellent environmental performance; its performance was even better than that of some of the large companies in the sample. This exceptional SME competed internationally and its management was very involved with environmental proactivity. In this sector, management involvement with environmental policy and international competition appeared to be much more decisive than company size in determining companies' environmental proactivity. 
The main obstacles to environmental proactivity faced by these companies were a lack of financial resources, institutional support, and access to information on environmental management systems. The main benefits expected by the companies after becoming more environmentally proactive were corporate image improvement, avoidance of punitive economic sanctions, long-term economic benefits, and the creation of new business opportunities (Segarra et al., 2011b).

\subsection{Tile industry case study}

A sample of 14 companies in the tile industry was chosen, of which $30 \%$ were large and $70 \%$ were SMEs. Fifty percent of the companies were multinational, and the remaining fifty percent conducted their activities only in Spain. Among the sample, 71\% of the companies were ISO 14001 certified.

Only $\mathrm{H} 2$ and $\mathrm{H} 3$ were supported by the results of this case study. Some companies in the sample were small, but competed internationally and had management teams that were highly involved with environmental issues. Therefore, is impossible to conclude based on data from the tile industry that small company size is a barrier to environmental proactivity. In this sector, like in the food industry, management involvement and international competition appeared to be much more decisive than company size in determining companies' environmental proactivity.

The main obstacles to environmental proactivity faced by these companies were a lack of financial resources, institutional support, and information on environmental management systems. The main benefits expected by the companies after becoming more environmentally proactive were corporate image improvement, avoidance of punitive economic sanctions, long-term economic benefits, and the creation of new business opportunities.

\section{Quantitative study}

In the quantitative study, the first and second hypotheses were tested on a broader sample.

H1: Large company size facilitates environmental proactivity, and small size is a barrier to it.

H2: International competition facilitates environmental proactivity.

Information for the quantitative study was obtained from the Technological Innovation Panel (PITEC) database. This database was compiled by the Spanish National Statistics Institute (INE). It includes listings of Spanish firms classified by innovation types, industrial sector, and location; 255 total variables are analyzed in the INE database. The sample analyzed for this study consisted of data collected in 2008 on 268 firms in the automotive industry. Variables analyzed in this study were selected according to the theoretical framework of the hypotheses and included net sales, total goods investment, number of employees, Spanish national market share, European market share, total investment in internal and external research and development (R\&D), number of full-time employees who work on R\&D activities, number of national patents, and number of European patents. An exploratory factor analysis was performed on all ten independent variables. The factor analysis yielded four main factors: size, open market orientation, formal innovative activity, and total innovation investment, which accounted for $80.83 \%$ of the variance. Among these four factors, factor size and export orientation had a consistent weight. The model's dependent variable is titled "EFECTO 8 " in the PITEC database; it measures the necessity for innovating firms to reduce environmental impact.

Correspondence analysis concluded that companies operating only in Spain tended to show little interest in environmental proactivity, whereas international companies showed medium or high interest rates in environmental proactivity (Segarra el al., 2011b).

\section{Conclusions}

Quantitative analysis demonstrated that large company size is a facilitator for environmental proactivity, verifying statements made by González-Benito and González-Benito(2006) and VargasVargas et al.(2010). The case studies of the tile industry and the food industry showed that small company size was not an insurmountable barrier to environmental proactivity. This confirmed Aragón-Correa et al.'s(2008)findings regarding the environmental proactivity of SMEs. H2 was supported by both the case studies and the quantitative analysis: companies that compete internationally demonstrated more proactive environmental behaviors. These findings validated Martín-Tapia et al.'s(2010) hypothesis that environmental proactivity aids companies in the internationalization process. It also stands to reason that international companies are externally pressured to minimize their impact on the environment much more than companies that do not export their products. Spanish industry lags behind other EU members in terms of its environmental conscience (Vargas-Vargas et al.,2010); therefore, export-oriented businesses are more likely to improve environmental performance. This demonstrates that international competition and environmental conscience are two factors that have a synergistic influence on environmental proactivity. H3was verified in the three case studies performed for this study: motivation and 
management involvement are necessary for the adoption of environmentally proactive policies, as stated by Villavicencio (2007).

In the automotive sector case study, all firms were ISO 14001 certified, because automobile manufacturers demand this certification in order to work with any company. However, it was also observed in the case study that many of the certification benefits were not properly understood. Once the companies became certified, some environmental principles cease to be prioritized by the companies, and therefore the positive effects of these principles diminish. This attitude demonstrates that some companies do not truly believe in the real advantages of certification and, and therefore, they lose certain potential benefits. Gadenne et al. (2009) observed several companies with "green appearances," but they implemented environmental practices poorly.

Another objective of this research was to confirm that environmental proactivity could provide benefits to companies in the Valencian Community industrial network. Eco-efficiency strategies can be recommended for virtually any business type, and lessening environmental impact by saving energy or reducing waste is often rewarded with cost savings. Many types of companies can reap benefits from adopting an environmentally proactive attitude, even companies that supply other companies, such as the automotive supply industry, those that generate waste, such as the food industry, or those that require high levels of energy consumption, such as the tile industry (Gabaldon, 2003). An eco-efficiency strategy is recommended for the Valencian industrial network, because it encourages companies to increase productivity by reducing environmental impact and its associated costs. This research can enable companies' management teams to acquire information on how to prioritize environmental investments. The benefits of ISO 14001 are widely recognized, and ISO 14001 certification is recommended whenever possible. Nevertheless, if certification is not possible, as is the case for many SMEs with limited resources, this should not be a reason to forget that environmental proactivity can be a source of competitive advantages. Simple systems can be adopted in order to improve energy use and minimize waste, and such systems would have direct, positive impacts on companies' productivity.

In conclusion, the benefits of institutional environmental proactivity should be suggested to industrial policy makers. Environmental proactivity improves companies' productivity, improves companies' corporate image, and can lead to business opportunities to fulfill the needs of new niche markets. Future lines of research could move towards larger quantitative studies, include other sectors or other regions, or compare and contrast analogous industrial sectors in different regions in order to analyze the effects of different environmental legislation.

Acknowledgments. The authors would like to thank the Spanish Science and Innovation Ministry for its support through the research project (EC02011-27369), and the Universitat Politècnica de Valènciafor its research funding to the project (PAID-06-2011).

\section{References}

1. Aragón-Correa JA, (1998) Strategic proactivity and firm approach to the natural environment. Academy of Management Journal 41(5): 556-567

2. Aragón-Correa JA, Sharma S, (2003) A Contingent Resource-based view of proactive corporate environmental strategy. Academy of Management Review, Vol 28. No. I. 71-88.

3. Aragón-Correa JA, Hurtado-Torres N, Sharma S, García-Morales V. (2008), Environmental strategy and performance in small firms: A resource-based perspective, Journal of Environmental Management, 86, 1, 88-103.

4. Butler, J. (2008) The Compelling "Hard Case" for "Green" Hotel Development, Cornell Hospitality Quarterly, 49 (3), pp. 234-244.

5. Buysse K, Verbeke A, (2003) Proactive environmental strategies: A stakeholder management perspective. Strategic Management Journal, 24, 453-470

6. Clarkson PM, Li Y, Richardson GD, Vasvari FP, (2011):”Does it really pay to be green? Determinants and consequences of proactive environmental strategies. J. Account Public Policy 30, 122-144

7. Darnall N, Henriques I, Sadorsky P, (2008) Do environmental management systems improve business performance in an international setting? Journal of International Management 14, 364376

8. Darnall N, Henriques I, Sadorsky P, (2010) Adopting proactive Environmental Strategy: The influence of Stakeholders and Firm size. Journal of Management Studies 47: September 2010

9. Delmas M, Hoffmann VH, Kuss M (2011) Under the tip of the Iceberg: Absorptive Capacity, Environmental Strategy, and competitive Advantages Business and Society 50(I) 116-154 
10. Fairchild R, (2008) The Manufacturing Sector's Environmental Motives: A Game-theoretic Analysis. Journal of Business Ethics, Vol. 79, No 3, pp. 333-334.

11. Gabaldon, S. Lopez, J. B. Carda, J. B. Legislación y gestiónmedioambiental en la producción de baldosascerámicas, Bol. Soc. Esp. Ceram. Vidr., 42 (3): 169-179, (2003).

12. Gadenne DL, Kennedy J, Mckeiver C, (2009) An empirical Study of environmental Awareness and Practices in SMEs. Journal of Business Ethics 84, 45-63

13. González-Benito J., González-Benito O. (2005), Environmental proactivity and business performance: an empirical analysis, Omega International. Journal of Management Science, 33, 1, $1-15$.

14. González-Benito J, González-Benito O, (2006), A Review of Determinant factors of Environmental Proactivity. Business Strategy and the Environment 15, 87-102 (2006)

15. González-Benito J, González-Benito O, (2010) A Study of Determinant Factors of Stake Environmental pressure perceived by industrial companies. Business Strategy and the Environment 19, 164-181

16. Haddock-Fraser JE, Tourelle M, (2010) Corporate Motivations for Environmental Sustainable Development: Exploring the role of consumers in stakeholder engagement. Business Strategy and the Environment 19, 527-542

17. IVEX, InstitutoValenciano de exportación, 2011.Información sectorial. http://www.ivex.es/dms/estudios/informacion_sectorial_CV/ceramicofeb/CERAMICOCV2011.pdf

18. King A.A, Lenox MJ (2001) Does It Really Pay to Be Green? An Empirical Study of Firm Environmental and Financial Performance Journal of Industrial Ecology Volume 5, Number 1 105-116

19. Martín-Tapia I, Aragón-Correa J, Rueda-Manzanares A, (2010) Environmental Strategy and exports in medium, small and micro-enterprises. Journal of World Business 45, 266-275

20. Melnyk S, Sroufe R, Calantone R, (2003) Assessing the impact of environmental management systems on corporate and environmental performance Journal of Operations Management 21 (2003) 329-351

21. Murillo-Luna J, Garcés-Ayerbe C, Rivera-Torres P, (2008) Why do patterns of environmental response differ? A stakeholders' pressure approach. Strategic Management Journal 29: 12251240

22. Orsato RJ, (2006) Competitive environmental strategies: when does it pay to be green? California Management Review Vol. 48, No.2

23. Porter M, Van der Linde C, (1995) Toward a New Conception of the EnvironmentCompetitiveness Relationship Journal of Economic Perspectives Vol. 9 No 4 pp. 97-118

24. Rivas J, Magadán M (2010) Less green taxes and more control over pollutant industries: a theoretical proposal Environmental Engineering and Management Journal, 9 (9) 1173-1177

25. Rondinelli D, Vastag G (2000) Panacea, common sense or just a label? The value of ISO 14001 Environmental management systems.European Management Journal Vol. 18, No. 5, pp. 499510,2000

26. Segarra-Oña M, Carrascosa-López C, Segura-García-del-Río B, Peiró-Signes A (2011b) Empirical analysis of the integration of environmental proactivity into managerial strategy. Identification of benefits, difficulties and facilitators at the Spanish automotive industry, Environmental Engineering and Management Journal, Forthcoming.

27. Vargas-Vargas M, Meseguer-Santamaría ML, Mondéjar-Jiménez J, Mondéjar-Jiménez JA, (2010) Environmental Protection Expenditure for Companies: A Spanish Regional Analysis, International Journal of Environmental Research, 4 (3) 373-378.

28. Villavicencio, J. M. (2007) Factoresqueinciden en el desempeñoexportador de lasPymes: unaaplicaciónempírica, Tec Empresarial, 1(4) 28-40.

\section{ConradoCarrascosa-López:}

Degree in Industrial Engineering by the Universidad Politécnica de Valencia.Assistant Professor in industrial competitiveness and economics, at the School of Industrial Engineering at the Universidad Politécnica, Valencia, Spain.Research Interest: Environmental proactivity, concarlo@ upvnet.upv.es

\section{Maria-del-Val Segarra-Oña:}

$\mathrm{PhD}$ in Management and Degree in Industrial Engineering. Associate Professor in Innovation, Competitiveness, Regional Development and Industrial Policies at the School of Industrial Engineering at the Universidad Politécnica, Valencia (Spain). Research Interest: Environmental proactivity, ecoinnovation and economic performance applied to industrial and service sectors. maseo@omp.upv.es. 


\section{Angel Peiró-Signes:}

$\mathrm{PhD}$ in Business Administration and Degree in Industrial Engineering. Assistant Professor in Analytical Accounting in Manufacturing firms and Strategic Management at the Faculty of Business Administration at the Universidad Politécnica de Valencia (Spain). Research Interest: Eco-innovation and economic performance of companies, applied to industrial and service sectors. anpeisig@omp.upv.es.

\section{Baldomero Segura-García-del-Rio:}

$\mathrm{PhD}$ Agronomist by the Universidad Politécnica de Valencia.Professor in Economics at the Agronomic Engineering in Universidad Politecnica, Valencia, Spain. Research interest: International economy, Risk analysis, Financial markets, RSC and the environment, bsegura@upvnet.upv.es 


\section{CAPítulo 6}

EXPLORANDO LA RELACIÓN ENTRE MEJORA CONTINUA, INNOVACIÓN Y COMPROMISO MEDIOAMBIENTAL DE LA GERENCIA, UN ESTUDIO EMPÍRICO. 


\title{
Explorando la relación entre mejora continua, innovación y compromiso medioambiental de la gerencia, un estudio empírico.
}

\author{
Conrado Carrascosa-López ${ }^{1}$, \\ Angel Peiró-Signes ${ }^{1}$, \\ María del Val Segarra-Oña ${ }^{1,2}$ \\ ${ }^{1}$ Universitat Politècnica de València, Spain \\ ${ }^{2}$ Inerte, International Network for Economic Research on Tourism and Environment
}

\begin{abstract}
La mejora continua es un campo de estudio y aplicación muy desarrollado a nivel empresarial. Por otra parte, el concepto innovación parece en el siglo XXI ser el remedio a cualquier tipo de problema de empresas y países. Estos conceptos unidos al interés creciente por el cuidado del medioambiente y la implantación de políticas medioambientalmente responsables tanto por parte de la sociedad, las empresas y las administraciones publicas nos lleva a preguntarnos si existe alguna relación entre estos conceptos. Así, el propósito de este trabajo es explorar la relación existente entre la voluntad de la gerencia a impulsar mejoras en la gestión medioambiental de la empresa con la aplicación de la mejora continua, las dos como componentes de una orientación innovadora. Para ello se analizan los datos relativos a 8038 empresas españolas recogidas en la base de datos PITEC ${ }^{\mathrm{i}}$ utilizando técnicas cuantitativas. Los resultados indican que efectivamente tras la clasificación de las empresas en grupos con diferente proactividad medioambiental, se observa que las empresas con mayor proactividad medioambiental muestran una relación directa con las actividades de innovación y mejora continua.
\end{abstract}

Key words: Environmental commitment, Innovation, Continuous improvement, Management.

\section{1.- Introducción.}

La mejora continua se define como el proceso planificado, organizado y sistemático de cambio continuado (Bond, 1999). Está basada en el ciclo de Deming, que consiste en cuatro fases: estudio de la situación actual, adquisición de información para proponer sugerencias de mejora; ajuste e implantación de propuestas seleccionadas; comprobación de resultados de las propuestas; implementación y estandarización de las propuestas con las necesarias modificaciones (García-Sabater, Marín-García, 2009). Las prácticas de mejora continua se han relacionado con la competitividad empresarial y se ha destacado la necesidad de de un compromiso por parte de la gerencia, inversión de tiempo y recursos (Albors et al., 2009)

Por otra parte, aunque los orígenes del concepto innovación fueron introducidos por Schumpeter en 1939, sigue siendo un campo de estudio actual en el ámbito académico. Este autor definió la 
innovación como un proceso que incluye la introducción en el mercado de un nuevo bien, la introducción de un nuevo método de producción, la apertura de un nuevo mercado y la conquista de una nueva fuente de suministro. Se han encontrado varias definiciones elaboradas por diferentes autores de dicho concepto. Según Gee (1981), innovación es el proceso en el cual a partir de una idea, invención o reconocimiento de necesidad, se desarrolla un producto, técnica o servicio útil. Según Perrin (1995) la innovación puede definirse como formas nuevas de hacer las cosas mejor o de manera diferente, muchas veces por medio de saltos cuánticos, en oposición a ganancias incrementales. En línea con esta última definición Trott (2008) propone la diferencia entre innovación radical e innovación incremental. Las innovaciones radicales suelen aparecer explorando nuevas tecnologías, pueden enfocarse a productos, procesos o servicios con novedades sin precedentes, crean un cambio dramático que puede transformar o incluso crear nuevos mercados o industrias. Las innovaciones incrementales surgen de la tecnología existente, enfocadas a mejoras en procesos, productos o servicios, mejoran la competitividad en los mercados o industrias existentes. El Manual de Oslo (2005) ha distinguido tradicionalmente entre la innovación de productos y procesos y, en la edición más reciente, considera también la organización y comercialización, pero aún no ha definido las innovaciones relacionadas con las cuestiones ambientales, lo que la academia está considerando como la eco-innovación (Peiró, Signes et al, 2011). Algunos motivos que animan a las empresas para innovar son: la mejora de la productividad (De Benito Valencia, 2000), la mejora de la calidad (Albors et al., 2009), la reducción de costes de producción (Bond, 1999). Del mismo modo la mejora continua se considera una herramienta para incrementar la competitividad (Albors et al., 2009).

El interés por el medioambiente es cada vez mayor tanto por parte de las empresas como a nivel social. Banerjee (2002), introduce el concepto de ecologismo de empresa, según el cual se integran los aspectos medioambientales en el proceso de planificación estratégica de la empresa. En la misma dirección, los principios de la responsabilidad social corporativa promueven la búsqueda del cumplimiento de los objetivos de los accionistas, compatibilizándola con la protección de la naturaleza y el desarrollo sostenible (Bravo et al. 2005). En la actualidad, el número de trabajos que han analizado los factores determinantes que promueven un comportamiento medioambiental responsable es importante (Ferrari et al, 2010). Entre estos factores, el apoyo y el compromiso de la gerencia son considerados como factores fundamentales necesarios para explicar el comportamiento medioambiental de una empresa (González-Benito y González-Benito, 2008, Aragón-Correa et al., 1998). Incluso es considerado como el central y esencial para el desarrollo de estrategias medioambientales proactivas (Gavrilescu, 2002, González-Benito, González-Benito, 2010,).

Estos tres conceptos diferentes, mejora continua, innovación y proactividad medioambiental, tienen cosas en común. La interrelación entre ellos se basa en que las consecuencias deseadas de la innovación, de la mejora continua y de la proactividad medioambiental convergen hacia una misma meta, la mejora de la productividad y por lo tanto de la competitividad de la empresa (Hitchens, 2005, Esty, 2006, Gonzalez-Benito, 2010). Esta relación, hasta el momento, no ha sido estudiada desde un punto de vista empírico. Ese será el objetivo de este trabajo, para lo que se realizará un estudio cuantitativo con información obtenida de la base de datos PITEC relacionando las variables innovación, mejora continua y orientación eco-innovadora

La estructura de este artículo es la siguiente, primero se va a hacer una revisión de literatura existente en mejora continua, innovación y proactividad medioambiental centrándonos en la relación entre estos tres conceptos. En el siguiente apartado se plantea la hipótesis del trabajo. A continuación se explica la metodología utilizada y las características de la muestra para el estudio empírico aplicado a los sectores industriales. Por último se plantean y discuten los resultados obtenidos y exponen las principales conclusiones, limitaciones del estudio y futuras líneas de investigación.

\section{2.- Revisión de literatura}

La revisión de literatura de los conceptos estudiados sigue la siguiente estructura. En primer lugar se introduce el concepto de mejora continua, con una explicación del mismo. En segundo lugar se introduce el concepto de proactividad medioambiental, se explican los factores que la promueven, y los beneficios que se esperan de ella. En tercer lugar se exponen las relaciones que se han encontrado en la literatura entre mejora continua e innovación. En cuarto lugar se explica la relación encontrada entre mejora continua y proactividad medioambiental. En último lugar se añade la relación entre proactividad medioambiental e innovación. 
La mejora continua es un sencillo concepto que puede ser aplicado para mejorar cualquier aspecto del ámbito de la producción: costes, calidad, flexibilidad y productividad (Bessant et al., 1993). Se puede definir como un proceso organizado y sistemático de cambios continuos. Está basada en el ciclo virtuoso de mejora de Deming que consiste en cuatro fases : "Plan", estudiar la situación actual y desarrollo de propuesta de cambios para mejorarla; "Do", obtención de información para elaborar la propuesta; "Check", examinar el efecto de los cambios para comprobar si el efecto es el deseado; "Action", implementación de la propuesta. El objetivo es corregir la causa del problema y no solo combatir sus síntomas para así erradicarlo y por lo tanto conseguir la mejora permanente (Bond, 1999). El objetivo de la mejora continua es conseguir mejoras en costes, calidad, flexibilidad o en la productividad, produciéndose estas mayoritariamente de una forma gradual o incremental (Bessant et al., 1993). La mejora continua representa el proceso de búsqueda de mejora en sí mismo, no solo la resolución de los problemas. Siguiendo este concepto básico se han desarrollado diferentes metodologías. Las más conocidas son: Lean manufacturing, six sigma, el cuadro de mando integral y la integración de las dos primeras como lean six sigma. (Bhuiyan y Baghel, 2005). Existe también la visión de la mejora continua como una materialización de iniciativas de calidad existentes como la gestión de la calidad total (Oakland, 1999), y la normas ISO (Terziovski et al. 2003, Bonilla y Aviles, 2008)

Podría definirse proactividad medioambiental como el comportamiento que incita a la implementación voluntaria de prácticas e iniciativas que conducen a mejorar la relación de la empresa con el medioambiente (González-Benito, González-Benito, 2006). Según Sharma y Vredenburg (1998) la proactividad medioambiental se refiere en la empresa a su habilidad para una gestión medioambiental avanzada consistente en prevenir voluntariamente sus impactos medioambientales.

Los factores determinantes de la proactividad medioambiental pueden clasificarse en internos de la empresa o externos a ella. Los internos son: el tamaño grande de la empresa, el formar parte de una corporación internacional y el apoyo y compromiso de la alta gerencia (González-Benito, GonzálezBenito, 2006). Los factores externos a la empresa son: el sector industrial al que se pertenece, ya que cada industria tiene un potencial diferente de polución y está sujeta a diferentes controles por parte de las administraciones públicas, instituciones y consumidores, y la localización, ya que de ella dependen tanto la legislación medioambiental como la presión social (González-Benito, González-Benito, 2006). También es importante nombrar la presión social hacia productos o servicios con menor impacto medioambiental (González-Benito, González-Benito, 2008) De entre estos determinantes, el considerado central y esencial para el desarrollo de estrategias medioambientales proactivas es la presión y compromiso de los accionistas (González-Benito, González-Benito, 2010). Aragón-Correa et al. (2008) estudiaron las pequeñas y medianas empresas con el fin de verificar que el tamaño de la empresa es relevante, pero no una condición determinista que impida desarrollar estrategias medioambientales proactivas. La relación entre la presión del accionariado y las prácticas medioambientales proactivas varían con respecto al tamaño de las empresas. Las empresas pequeñas son más sensibles a dichas presiones percibidas, y estas surten como efecto un mejor comportamiento medioambiental (Darnall et al., 2010). Con respecto a la teoria de Stakeholders, Gadenne et al. (2009) observaron que a pesar de encontrar empresas con accionistas / gerentes con actitudes "verdes", sin embargo el nivel de implementación de prácticas medioambientales en dichas empresas era pobre. Estas observaciones indican la necesidad de explorar la conexión entre las presiones ejercidas sobre los gerentes, y las acciones y decisiones concretas tomadas por ellos. La presión transmitida a los gerentes no siempre se ve manifestada en acciones de la misma intensidad.

Es necesario mirar dentro de la empresa, para comprender mejor cuales son las capacidades que apoyan la aparición de estrategias sostenibles con éxito, considerando fundamental el concepto de capacidad de absorción, se refiere este concepto a la habilidad de las empresas para reconocer el valor de nueva información, su capacidad para asimilarla y aplicarla para su beneficio (Delmas et al., 2011). Así mismo, no siempre el hecho de mostrar actitudes favorables hacia el medioambiente está asociado con la toma de acciones para mejorar el impacto medioambiental de la empresa, por lo que se recomiendan los estudios empíricos. (Gadenne et al. 2009)

Existen estudios en los que se relaciona la proactividad medioambiental de la empresa con la obtención de diferentes beneficios. Estos beneficios suelen aparecer con la integración de la orientación medioambiental de la empresa con su estrategia empresarial (Bravo et al. 2005). Por ejemplo, AragónCorrea (1998), define los efectos positivos de la proactividad medioambiental como una nueva área de ventaja competitiva. Hay situaciones en las que el comportamiento proactivo produce beneficios tanto 
para el medio ambiente como para la empresa (King y Lenox, 2001). Los estudios cada vez van concretando y analizando cada uno de los beneficios obtenidos, como la mejora en la reputación de la empresa (Buysse y Verbeke, 2003), la obtención de efectos positivos tanto en el propio desempeño de la empresa y en sus las actividades de marketing (González-Benito, 2005). En la misma línea, Gadenne et al. (2009) añaden y detallan más beneficios para las empresas, entre los que se encuentran: reducción de desechos, ahorro de costes, aumento de la satisfacción de los clientes, mejoras en los productos y en las relaciones públicas de las empresas. Los estudios más recientes en este campo añaden que la proactividad medioambiental es una ayuda para los procesos de internacionalización (Martín-Tapia et al, 2010) e incluso para mejorar en los recursos financieros (Clarkson et al., 2011).

La relación entre mejora continua e innovación es una cuestión que goza de aceptación en la literatura. Actualmente resulta habitual asociar la mejora continua como una forma de innovación incremental (Marín-García et al. 2008, Bessant, 1998). Incluso también ha sido definida como un proceso de toda la organización de innovación incremental (Bessant y Francis, 1999) cuyos miembros suelen implicarse en los procesos de innovación. Si bien existen diferentes enfoques que discrepan de esta consideración y dudan que la mejora continua pueda identificarse como innovación, sobre todo en el caso de innovaciones radicales (Cilleruelo et al. 2008) .

Siguiendo a Martín Castilla (2007) la innovación se ha impuesto como la única vía de desarrollo organizativo para la gestión del cambio a lo largo del tiempo y la formulación de soluciones de mejora creativas en respuesta a los retos que crea el entorno, enlazando ambos términos con la teoría de la contingencia aplicada por Gertsen (2001) para analizar los aspectos contingentes de la mejora continua con la evolución empresarial.

Relacionando el concepto de mejora continua con la gestión medioambiental proactiva Hart (1995) indica que el concepto de mejora continua es incluido entre los recursos relacionados con la gestión medioambiental proactiva. En el trabajo de Darnall et al. (2006), se subraya que los sistemas de gestión medioambiental están basados en el modelo de mejora continua e incluso se indica que para mantener un sistema de gestión medioambiental se necesitan las capacidades de la mejora continua y es a través de ellas como se consigue facilitar los programas de reducción de residuos medioambientales. En su estudio sobre la norma ISO 14001 Morrow y Rondinelli (2002) indican esta misma relación. En esta misma dirección, el propósito principal del concepto de lean manufacturing es la eliminación de residuos en todas las áreas de la empresa, incluyendo el área de residuos medioambientales (Bhuiyan y Baghel, 2005). Otros autores destacan que la producción sostenible es el resultado último de la mejora continua (De Ron, 1997). Delmas et al. (2011) afirman que la estrategia para implementar programas de mejora medioambiental necesita de la implicación de mucha gente realizando esfuerzos de mejora continua. En su trabajo sobre la gestión medioambiental, Gupta (1994), indica que esta requiere de la evaluación completa de todos los procesos, y se esfuerza por lograr una mejora continua en ellos.

La relación entre innovación y gestión medioambiental es señalada por muchos autores. Por ejemplo Angell y Klassen (1999) relacionan las innovaciones tecnológicas como una de las bases sobre la que se sustentan las mejoras medioambientales. El interés combinado en competitividad y responsabilidad ecológica lleva con frecuencia a innovaciones en productos, procesos y políticas que de otro modo no se realizarían (Bansal, Roth, 2000). Las prácticas medioambientales proactivas son innovaciones de gestión que necesitan del compromiso de la organización hacia la mejora del medioambiente (Darnall et al. 2010), este mismo autor indica que las empresas pequeñas, por su menor tamaño y mayor flexibilidad, suelen ser innovadoras más eficaces y por lo tanto tiene una mayor inclinación a invertir en cambios proactivos medioambientales Delmas et al. (2011) basan su investigación en tres estrategias que reconcilian competitividad y proactividad medioambiental: reducción de costes, creación de valor animando a la diferenciación de producto e innovación, y la mejora de la reputación. Para ello es un factor fundamental a tener en cuenta la capacidad de absorción de la empresa. Una de las motivaciones por la cual las empresas alemanas adoptan sistemas de gestión medioambiental es para promover innovaciones tanto de procesos como de productos (Morrow y Rondinelli, 2002). Uno de los aspectos tenidos en cuenta para medir la proactividad medioambiental de una empresa es su tendencia a la innovación (Murillo et al. 2008).

Se ha observado cómo se relacionan entre sí los conceptos objetos de este trabajo, mejora continua con innovación, mejora continua con proactividad medioambiental e innovación con proactividad medioambiental. Porter y Van der Linde (1995) relacionan la legislación medioambiental como una fuente que fomenta la innovación e incita a la mejora continua de los procesos. Sin embargo 
no se ha encontrado en el ámbito académico literatura empírica con análisis cuantitativos que relacione los tres conceptos a la vez Esta es la razón principal que ha motivado este estudio, y la exploración a través del análisis cuantitativo de dichos tres conceptos a la vez y lo que nos lleva a plantear la siguiente hipótesis:

H1: Las empresas cuya gerencia impulsa programas de mejora continua e innovación muestran interés en mejorar su gestión medioambiental.

\section{3.- Muestra y metodología.}

Para el estudio se han utilizado datos provenientes del panel de innovación tecnológica PITEC (2009) que monitorean las actividades de innovación de las empresas españolas. La base de datos depende del INE (Instituto Nacional de Estadística) y se estructuro con el asesoramiento de académicos y expertos. Los primeros datos disponibles son de 2004 y se actualiza anualmente. Incluye un total de 255 variables.

Con anterioridad se ha utilizado para avanzar en la comprensión de la innovación en las empresas y las diferentes estrategias implementadas (Vega-Jurado et al., 2009), y también para identificar los factores que influyen en la orientación sostenible de las empresas (Segarra et al., 2011).

La muestra está compuesta por 8038 empresas españolas. Se han seleccionado las variables relacionadas con la mejora continua y la innovación de acuerdo con la teoría previamente expuesta. La preocupación medioambiental al innovar (denominado Objetivo 11 en la base de datos PITEC) determinada por la importancia de la reducción del impacto medioambiental en las actividades de innovación, muestra la proactividad medioambiental de la empresa y se considera la variable dependiente para poder analizar la influencia que la mejora continua y la innovación tienen sobre ella. Cuadro 1.

Las variables seleccionadas de acuerdo a la revisión de la literatura efectuada se presentan en el

Cuadro 1. Definición de las variables.

\begin{tabular}{|c|c|c|}
\hline VARIABLE & DEFINICION & $\begin{array}{c}\text { CODIGO } \\
\text { RESPUESTA }\end{array}$ \\
\hline OBJET1 & $\begin{array}{l}\text { Importancia objetivo innovación tecnológica: Gama más } \\
\text { amplia de bienes o servicios }\end{array}$ & 1,2 3,4,Blanco \\
\hline OBJET2 & $\begin{array}{l}\text { Importancia objetivo innovación tecnológica: Sustitución de } \\
\text { productos o procesos anticuados }\end{array}$ & 1,2 3,4,Blanco \\
\hline OBJET3 & $\begin{array}{l}\text { Importancia objetivo innovación tecnológica: Penetración en } \\
\text { nuevos mercados }\end{array}$ & 1,2 3,4,Blanco \\
\hline OBJET4 & $\begin{array}{l}\text { Importancia objetivo innovación tecnológica: Mayor cuota de } \\
\text { mercado }\end{array}$ & 1,2 3,4,Blanco \\
\hline OBJET5 & $\begin{array}{l}\text { Importancia objetivo innovación tecnológica.: Mayor calidad } \\
\text { de los bienes o servicios }\end{array}$ & $1,23,4$,Blanco \\
\hline OBJET6 & $\begin{array}{l}\text { Importancia objetivo innovación tecnológica: Mayor } \\
\text { flexibilidad en la producción o la prestación de servicios }\end{array}$ & 1,2 3,4,Blanco \\
\hline OBJET7 & $\begin{array}{l}\text { Importancia objetivo innovación tecnológica: Mayor } \\
\text { capacidad de producción o prestación de servicios }\end{array}$ & 1,2 3,4,Blanco \\
\hline OBJET8 & $\begin{array}{l}\text { Importancia objetivo innovación tecnológica: Menores costes } \\
\text { laborales por unidad producida }\end{array}$ & 1,2 3,4,Blanco \\
\hline OBJET9 & $\begin{array}{l}\text { Importancia objetivo innovación tecnológica: Menos } \\
\text { materiales por unidad producida }\end{array}$ & 1,2 3,4,Blanco \\
\hline OBJET10 & $\begin{array}{l}\text { Importancia objetivo innovación tecnológica: Menos energía } \\
\text { por unidad producida }\end{array}$ & 1,2 3,4,Blanco \\
\hline
\end{tabular}




\begin{tabular}{|c|c|c|}
\hline OBJET11 & $\begin{array}{l}\text { Importancia objetivo innovación tecnológica: Menor impacto } \\
\text { medioambiental }\end{array}$ & 1,2 3,4,Blanco \\
\hline OBJET14 & $\begin{array}{l}\text { Importancia objetivo innovación tecnológica: Aumento del } \\
\text { empleo total }\end{array}$ & 1,2 3,4,Blanco \\
\hline OBJET15 & $\begin{array}{l}\text { Importancia objetivo innovación tecnológica: Aumento del } \\
\text { empleo cualificado }\end{array}$ & $1,23,4$,Blanco \\
\hline OBJET16 & $\begin{array}{l}\text { Importancia objetivo innovación tecnológica: Mantenimiento } \\
\text { del empleo }\end{array}$ & $1,23,4$,Blanco \\
\hline FACE1 & $\begin{array}{l}\text { Importancia factores: falta de fondos dentro de la empresa o } \\
\text { grupo }\end{array}$ & $1,23,4$,Blanco \\
\hline FACE2 & $\begin{array}{l}\text { Importancia factores: falta de financiación externa a la } \\
\text { empresa }\end{array}$ & 1,2 3,4,Blanco \\
\hline FACE3 & Importancia factores: costes de innovación elevados & 1,2 3,4,Blanco \\
\hline FACl1 & Importancia factores: falta de personal cualificado & $1,23,4$,Blanco \\
\hline FACI2 & Importancia factores: falta de información sobre tecnología & 1,2 3,4,Blanco \\
\hline FACI3 & Importancia factores: falta de información sobre mercados & $1,23,4$, Blanco \\
\hline FACl4 & $\begin{array}{l}\text { Importancia factores: dificultad en encontrar socios para la } \\
\text { cooperación en innovación. }\end{array}$ & 1,2 3,4,Blanco \\
\hline OTROFAC1 & $\begin{array}{l}\text { Importancia factores: Mercado dominado por empresas } \\
\text { establecidas }\end{array}$ & 1,2 3,4,Blanco \\
\hline OTROFAC2 & $\begin{array}{l}\text { Importancia factores: demanda incierta de bienes y servicios } \\
\text { innovadores }\end{array}$ & $1,23,4$,Blanco \\
\hline OTROFAC3 & Importancia factores: no necesitadas por innovaciones previas & 1,2 3,4,Blanco \\
\hline OTROFAC4 & $\begin{array}{l}\text { Importancia factores: no necesitadas por falta de demanda de } \\
\text { innovaciones }\end{array}$ & $1,23,4$,Blanco \\
\hline INORGN1 & $\begin{array}{l}\text { Innovación organizativa de (t-2) a t: Nuevas prácticas } \\
\text { empresariales en la organización }\end{array}$ & 1,0,Blanco \\
\hline INORGN2 & $\begin{array}{l}\text { Innovación organizativa de (t-2) a t: Nuevos métodos de } \\
\text { organización de los lugares de trabajo en su empresa con el } \\
\text { objetivo de un mejor reparto de responsabilidades y toma }\end{array}$ & 1,0,Blanco \\
\hline INORGN3 & $\begin{array}{l}\text { Innovación organizativa de }(\mathrm{t}-2) \text { a t: Nuevos métodos de } \\
\text { gestión de las relaciones }\end{array}$ & 1,0,Blanco \\
\hline INCOMN1 & $\begin{array}{l}\text { Innovación comercialización de (t-2) a t: Modificaciones } \\
\text { significativas del diseño del }\end{array}$ & 1,0,Blanco \\
\hline INCOMN2 & $\begin{array}{l}\text { Innovación comercialización de }(\mathrm{t}-2) \text { a t: Nuevas técnicas o } \\
\text { canales para la promoción }\end{array}$ & 1,0,Blanco \\
\hline INCOMN3 & $\begin{array}{l}\text { Innovación comercialización de (t-2) a t: Nuevos métodos para } \\
\text { el posicionamiento del }\end{array}$ & 1,0,Blanco \\
\hline INCOMN4 & $\begin{array}{l}\text { Innovación comercialización de (t-2) a t: Nuevos métodos para } \\
\text { el establecimiento de los }\end{array}$ & 1,0,Blanco \\
\hline
\end{tabular}

Aunque las escalas Likert u ordinales de 5 puntos se han utilizado ampliamente en estudios de regresión tratándolos como escalas continuas, muchos estudios sobre estos métodos sugieren que debe de haber un mínimo de clases para realizarlo, Achen (1991) propuso que como mínimo debía haber 5 clases, Berry (1993) estableció que 5 o menos clases era inadecuado mientras otros indican un mínimo de 7 clases. En consecuencia, a pesar de la gran cantidad de datos, en este estudio hemos considerado más adecuado la utilización de otra metodología.

Las variables seleccionadas en la encuesta PITEC no se encuentran agrupadas en componentes previamente definidos y proporcionan información muy específica sobre los aspectos de los que se realiza el estudió. Sin embargo, varios de estos elementos pueden representar constructos similares o idénticos. En consecuencia, se ha realizado un Análisis factorial exploratorio para determinar las medidas para cada uno de los constructos teóricos subyacentes (Johnson y Wichern, 2001 Hair et al., 1998). Para cada grupo, se realizo un análisis factorial (método Varimax) para descubrir la estructura latente de cada conjunto de 
preguntas. El análisis factorial permite además reducir un gran número de variables a un número menor de factores para modelizar los efectos (Hair et al., 1998).

Las variables fueron asignadas a los factores en los que tuvieron la mayor carga. Utilizamos el coeficiente $\alpha$ de Cronbach para verificar la confiabilidad de cada factor. Valores de $\alpha$ iguales o superiores a 0,70 se consideran aceptables para escalas existentes y superiores a 0,60 para nuevas escalas (Nunnally, 1978; Churchill, 1979).

El cuadro 2 presenta la rotación Varimax de componentes principales resultado del análisis. Para mayor claridad, las puntuaciones de los factores inferiores a 0,4 no se muestran en la Tabla

Cuadro 2. Análisis factorial (rotación Varimax)

\begin{tabular}{lcc}
\hline Factores & Factor 1 & Factor 2 \\
Porcentaje de varianza explicada & 25,43 & 12,93 \\
Autovalores & 7,88 & 4,01 \\
\hline $\begin{array}{l}\text { Calidad interna relacionada con la } \\
\text { mejora continua ( } \alpha=0,885)\end{array}$ & & \\
OBJET6 &, 720 & \\
OBJET7 &, 753 & \\
OBJET8 &, 817 & \\
OBJET9 &, 807 & \\
OBJET10 &, 790 & \\
Barreras internas que afectan a la & & \\
innovación y mejora continua. & & \\
( $\alpha=0,877)$ & &, 797 \\
FACl1 & &, 866 \\
FACI2 & &, 842 \\
FACI3 & &, 610 \\
FACl4 & &, 573 \\
OTROFAC1 & &, 563 \\
OTROFAC2 & &
\end{tabular}

Calidad externa relacionada con la mejora de la calidad percibida por el cliente. $(\alpha=0,883)$

OBJET1

OBJET2

OBJET3

OBJET4

OBJET5

Grado de innovaciones de tipo comercial $(\alpha=0,763)$

INCOMN1

INCOMN2

INCOMN3

INCOMN4

Mejora de la calidad laboral.

$(\alpha=0,899)$

OBJET14

OBJET15

Factores externos que afectan a la innovación. $(\alpha=0,883)$ 
Innovaciones de tipo organizativo

$(\alpha=0,782)$

INORGN1

INORGN2

INORGN3

Otros factores que dificultan los

procesos de innovación $(\alpha=0,682)$

OTROFAC3

KMO 0,893 Variabilidad explicada 76,37\% Análisis de Componentes principales con rotación Varimax. Nota: Para mayor claridad se ha suprimido los factor scores inferiores a 0,4.

KMO 0,885. Variabilidad explicada $68,63 \%$

El análisis factorial muestra que los datos se agrupan en 8 factores que denominaremos:

Factor 1: Calidad interna relacionada con la mejora continua. Unas de los principales objetivos de la mejora continua consiste en la obtención de "ceros", cero stock, cero desperdicio,.. Alineada con esta filosofía se encuentra las acciones de mejora o de innovación destinadas a la mejora de la flexibilidad productiva, mejora de la capacidad, reducción de costes y de consumo de materiales y energía (Papadopoulos, 2011).

Factor 2: Barreras internas que afectan a la innovación y mejora continua. Este factor recoge aquellas barreras de carácter interno que están afectando a los procesos de mejora continua. Se recogen los aspectos como la falta de personal cualificado o de información. La falta de información relativa a la innovación conforma la llamada capacidad de absorción. (Hervás-Oliver, Albors-Garrigós, 2009) (Delmas et al., 2011) que junto a la mejora de las capacidades y habilidades de los trabajadores son elementos fundamentales e imprescindibles para que mantener un proceso de mejora continua sostenido en el tiempo. Por otra parte, se recoge en este factor las incertidumbres internas recogidas respecto a la información de los mercados, lo que en conjunto está determinando la visión interna de la empresa respecto a la utilización de sus habilidades para afrontar el cambio que supone el enfoque de mejora continua.

Factor3: Calidad externa relacionada con la mejora de la calidad percibida por el cliente. Este factor recoge aspectos de innovación o mejora que pretenden mejorar la posición competitiva de la empresa recogiendo aquellas innovaciones y mejoras orientadas a mejorar la parte final de la cadena de valor de la empresa, complementando así la búsqueda de la mejora operativa productiva que recoge el factor 1. Son objetivos de la iniciativa innovadora (Davenport, 1993).

Factor4: Mientras los factores anteriores recogen actitudes, este factor determina el grado de innovaciones de tipo comercial que efectivamente se han llevado a cabo en los últimos 2 años. Esta dinámica de adopción de innovaciones es estudiada por (Damanpour, 2001).

Factor 5: Mejora de la calidad laboral. Este factor recoge objetivos de mejora de la estabilidad y calidad laboral de los trabajadores como uno de los objetivos deseados del proceso de innovación (Pianta, 2003).

Factor 6: Factores externos que afectan a la innovación. Recoge los aspectos, principalmente la falta de financiación, que pueden lastrar el proceso de innovación. Al igual que ocurre en la innovación, la mejora continua requiere del apoyo de la dirección mediante la aportación de los recursos necesarios para las actividades de mejora continua: tiempo, personal y recursos económicos para realizar las mejoras. (Segarra et al., 2011).

Factor 7: Este factor determina el grado de innovaciones de tipo organizativo que efectivamente se han llevado a cabo en los últimos 2 años. Damanpour (2001) explica como son adoptadas las innovaciones organizativas y su relación con las innovaciones de producto. 
Factor 8: Otros factores que dificultan los procesos de innovación. Refleja la actitud de la empresa respecto del proceso de cambio a través de la innovación o proceso de mejora continua. La percepción de la no necesidad de cambio, es una reconocida barrera a actividades de innovación o mejora continua $\mathrm{y}$, por tanto, es un factor a tener en cuenta, ya que las innovaciones comerciales dependen también de las fuerzas del mercado (Kline, Rosenberg, 1986)

Para el análisis, teniendo en cuenta los resultados previos obtenidos en otros estudios se distinguió entre 2 grupos: empresas orientadas y no orientadas. Se creó una variable modificada sobre la variable objetivo11 que representa la proactividad medioambiental en la base de datos PITEC. De esta forma, la nueva variable toma el valor de $1 \mathrm{si}$ es altamente proactiva (objetiv11 =1) o si es medianamente proactiva (objet11=2) y 0 si se trata de una empresa con baja proactividad o no proactiva (objet11=3 o 4). Estudios anteriores (Segarra et al., 20011b, Peiró-Signes et al., 2011) han demostrado que existen pocas diferencias entre los grupos 3 y cuatro y puesto que lo que se pretende es destacar cuales son las características entre las empresas que optan por una actitud proactiva y no proactiva o poco proactiva, la separación de estas dos categorías no aporta información adicional para las conclusiones de este estudio.

\section{Análisis y resultados.}

En este caso, las medida de los distintos factores varía de forma significativa debido al número de variables involucradas y a las características de dichas variables. Por tanto, la utilización de las puntuaciones factoriales para el tratamiento estadístico a partir del análisis factorial es recomendable sobre otros métodos como la utilización de subescalas. Además, la estandarización realizada en el proceso permite una fácil comparación de los resultados posteriores obtenidos para cada uno de los factores independientemente de cómo se hayan formado.

Sobre las puntuaciones de los factores obtenidos en el análisis factorial para cada una de las categorías del Objetivo11 modificado se realizó un test ANOVA para determinar si existen diferencias significativas en las puntuaciones entre las dos categorías.

Los resultados muestran diferencias significativas entre los grupos para cada uno de los 8 factores extraídos. Podemos observar que ,las empresas orientadas medioambientalmente, puntúan más bajo en todos los factores menos en el 4 y 7, debido a la codificación de respuestas (alto=1, medio=2, bajo $=3$, no relevante $=4$ ) realizada en la encuesta. Esto permite afirmar que tienen un mayor grado de proactividad, ya que cuanto menor sea el valor en la respuesta (mayor proactividad) menor es el valor de la puntuación del factor, al ser ésta la representación de la posición de la observación tras normalizar la muestra según una normal de media 0 y desviación típica 1 . Por otra parte, puntúan más alto en los factores 4 y 7, lo que indica que llevan a cabo un mayor número de innovaciones de tipo organizacional o comercial, es decir, que no sólo son más proactivas sino que también son más activas en la realización de innovaciones o mejoras.

Cuadro 3. Análisis de medias (Anova)

\begin{tabular}{|c|c|c|c|c|c|}
\hline Factor & Grupo & Media & $\begin{array}{c}\text { Desviación } \\
\text { típica } \\
\end{array}$ & $\mathrm{F}$ & Sig. \\
\hline \multirow[t]{2}{*}{ Factor 1} & No orientadas & ,358 & ,915 & 1513,7 & ,000 \\
\hline & Orientadas &,- 443 & ,920 & & \\
\hline \multirow[t]{2}{*}{ Factor 2} & No orientadas & ,052 & 1,046 & 26,5 & ,000 \\
\hline & Orientadas &,- 064 & ,936 & & \\
\hline \multirow[t]{2}{*}{ Factor 3} & No orientadas & ,226 & 1,092 & 542,5 & ,000 \\
\hline & Orientadas &,- 280 & ,787 & & \\
\hline
\end{tabular}




$\begin{array}{llrrrr}\text { Factor } 4 & \text { No orientadas } & -, 058 & , 883 & 33,3 & , 000 \\ & \text { Orientadas } & , 071 & 1,124 & & \\ & & & & & \\ \text { Factor 5 } & \text { No orientadas } & , 248 & , 844 & 661,7 & , 000 \\ & \text { Orientadas } & -, 307 & 1,089 & & \\ & & & & & , 062 \\ \text { Factor 6 } & \text { No orientadas } & , 019 & 1,043 & 3,5 & \\ & \text { Orientadas } & -, 023 & , 944 & & \\ & & & & & \\ \text { Factor 7 } & \text { No orientadas } & -, 071 & , 940 & 51,1 & \\ & \text { Orientadas } & , 088 & 1,063 & & \\ & & & & & \\ & \text { No orientadas } & -, 037 & 1,033 & 13,7 & \\ \text { Factor 8 } & \text { Orientadas } & , 046 & , 955 & & \\ & & & & & \\ & & & \end{array}$

A continuación, se desarrolló un modelo discriminante con SPSS sobre la base de las ocho dimensiones relacionadas con la innovación y mejora continua y asumiendo que las empresas fueron clasificadas originalmente en dos grupos (variable dependiente) de acuerdo con la variable Objet11 modificada. El análisis discriminante se usa para clasificar casos dentro de una variable dependiente categórica, generalmente dicótoma. Permite entre otras, determinar el porcentaje de varianza de la variable dependiente explicado por las variables independientes y evaluar la importancia relativa de las variables independientes a la hora de clasificar un caso dentro de la variable dependiente.

La ventaja de esta técnica sobre otras como la regresión logística es que no realiza ajusta el modelo a los datos para obtener la variable dependiente sino que la clasificación en un grupo u otro de la variable dependiente se realiza buscando la combinación lineal de variables independientes que mejor discrimina entre los grupos y, por tanto, no asume que existe una relación entre las independientes y la dependiente. De esta forma, la agrupación se realiza para incrementar el grado de varianza explicada, permitiendo la determinación de grupos diferenciados y cuales son las características que permiten diferenciar estos grupos. Posteriormente comparamos los grupos obtenidos en el análisis con la clasificación que hemos realizado en función de su proactividad medioambiental según la variable Objetivo 11 modificada, de manera que si el grado de aciertos es suficientemente elevado, podemos concluir que las funciones y, consecuentemente, los factores que la componen, están influyendo en esta clasificación y, por tanto, en la proactividad medioambiental. El Cuadro 4 muestra los coeficientes para cada una de las dos funciones discriminantes, así como lambda de Wilk y las puntuaciones medias para cada uno de los tres grupos (Hair et al., 1998).

\section{Cuadro 4. Coeficientes estandarizados de las funciones discriminantes canónicas}

\begin{tabular}{ll}
\hline & \multicolumn{1}{c}{ Función discriminante } \\
\hline Factor 1 &, 787 \\
\hline Factor 2 &, 123 \\
Factor 3 &, 525 \\
\hline Factor 4 &,- 138 \\
Factor 5 &, 571 \\
\hline Factor 6 &, 045 \\
Factor 7 &,- 171 \\
\hline Factor 8 &,- 089 \\
Wilk's lambda & 0,686 \\
& $\mathrm{p}<0,05$ \\
\hline Mean scores & \\
\hline
\end{tabular}




\begin{tabular}{ll}
\hline Grupo 0 & 0,608 \\
Grupo 1 &,- 752 \\
Varianza explicada & $100 \%$ \\
\hline
\end{tabular}

Cuadro 5. Clasificacion de los resultados.

\begin{tabular}{|c|c|c|c|c|c|c|}
\hline \multicolumn{7}{|c|}{ Resultados de la clasificación } \\
\hline \multirow{2}{*}{\multicolumn{4}{|c|}{ obj11mod }} & \multicolumn{3}{|c|}{ Grupo de pertenencia pronosticado } \\
\hline & & & & 0 & 1 & Total \\
\hline \multirow{3}{*}{ Original } & \multirow{3}{*}{\multicolumn{2}{|c|}{ Recuento (\%) }} & 0 & $3166(71,23 \%)$ & $1279(28,77 \%)$ & 4445 \\
\hline & & & 1 & $806(22,43 \%)$ & $2787(77,57 \%)$ & 3593 \\
\hline & & & Total & 3972 & 4066 & 8038 \\
\hline \multirow[t]{2}{*}{ Validación cruzada } & \multirow{2}{*}{\multicolumn{2}{|c|}{ Recuento (\%) }} & 0 & $3164(71,18 \%)$ & $1281(28,82 \%)$ & 4445 \\
\hline & & & 1 & $812(22,6 \%)$ & $2781(77,4 \%)$ & 3593 \\
\hline Total 3976 & 4062 & 8038 & & & & \\
\hline
\end{tabular}

Clasificados correctamente el $74,1 \%$ de los casos agrupados originales.

Clasificados correctamente el 74,0\% de los casos agrupados validados mediante validación cruzada.

Criterio de máxima probabilidad $=55,3 \%$. Criterio de probabilidad proporcional $=63,2 \%$

Como se muestra en la Cuadro 4, la función discriminante es estadísticamente significativa basado en lambda de Wilk ( $p<0,05)$. El coeficiente para el factor 1 , que se encuentra fuertemente relacionado con los procesos de mejora continua como se ha demostrado anteriormente, y los coeficientes para los factores 5 y 3, que representan por un lado, la viabilidad de la empresa y del empleo y, por otro, la calidad externa o percibida por el cliente, ambos objetivos fundamentales de los procesos de mejora continua, fueron los más altos y sustancialmente más altos que los otros coeficientes de la función discriminante.

Es una práctica común para validar los modelos discriminantes estimados mediante la técnica de validación cruzada (por ejemplo, U-Method o jackknifing). La principal diferencia es que el U-Method se centra en la precisión de la clasificación, mientras que jackknifing se centra en la estabilidad de las funciones discriminantes. En nuestro estudio, el propósito del análisis discriminante fue demostrar la exactitud de la clasificación y por lo tanto, se utilizó el U-Method de validación cruzada de los resultados. Los resultados se presentan en la Tabla 5 y muestran que la validación cruzada clasifica con bastante precisión y supera de nuevo el criterio de probabilidad proporcionalidad y el criterio de máxima probabilidad.

Después de los anteriores el objetivo de búsqueda de la calidad externa se estableció como el tercero en importancia en dicha función.

Por otro lado, la segunda función discriminante viene determinada fundamentalmente por el factor 2 y el 3, pero la variabilidad explicada por la misma es mínima 1,1\% por lo que podemos concluirLos coeficientes del resto de factores analizados indican que éstos tienen una influencia al menos tres veces inferior a la de los factores citados anteriormente.

Por tanto, podemos afirmar que los dos factores de los estudiados que influyen significativamente en la proactividad medioambiental al innovar son, la búsqueda de innovaciones internas, que está estrechamente relacionada con las actividades de mejora continua y, la búsqueda de una mejora en la estabilidad y calidad del empleo, que es un objetivo que subyace en cualquier programa de mejora continua, ya que se busca garantizar la viabilidad y la competitividad de la empresa en el largo plazo. 
La Fig. 2 muestra la posición relativa de cada cluster a lo largo de los dos ejes discriminantes.

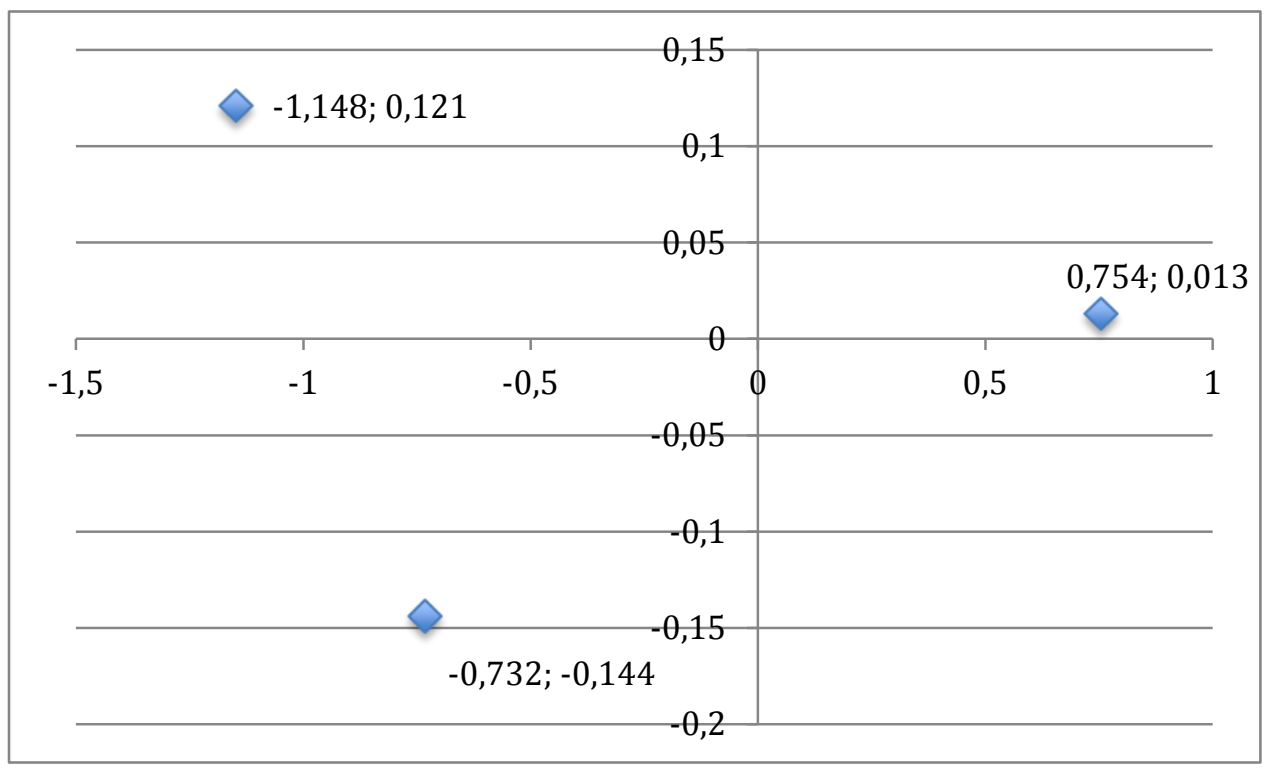

Fig. 2. Cluster a lo largo de los dos ejes discriminantes.

Además, el grupolos de centroides (medias de conglomerados) para cada uno de los tres grupos difieren sustancialmente. Las puntuaciones de la función discriminante fueron estandarizadas para que la totalidad de la muestra tuviera una media de 0,00 y una desviación estándar de 1,00. Esto permite comparar y diferenciar fácilmente los grupos. Por ejemplo, la media para el Grupo 0, empresas no orientadas, se encuentra en 0,608 y para el Grupo 1, empresas orientadas, la media se encuentra en $-0,752$.

Los centroides de grupo nos indican que el grupo 1 puntúa de 0,75 desviaciones típicas respecto de la media del conjunto de datos, lo que implica que puntúa más bajo en los factores 1,5 y 3 . Teniendo en cuenta como se construyen estos factores y que las preguntas relacionadas con los mismos tienen la siguiente codificación 1=Alta, 2=Media, 3=Baja y 4=No relevante/no empleada, resulta que las empresas del grupo 1, empresas orientadas medioambientalmente, muestran una mayor orientación hacia las actividades de mejora continua respecto al grupo 0, empresas no orientadas medioambientalmente. Lo anterior que queda reflejado en la gran distancia entre los centroides de los citados grupos.

A pesar de que es sumamente importante contar con una función estadísticamente significativa, también es muy importante que la función discriminante tenga un buen desempeño en la clasificación de las empresas en sus grupos originales para la calibración y validación de las muestras.

En el cuadro 5 se presentan los resultados de la clasificación basada en la función discriminante. Las filas del cuadro 5 muestran la clasificación actual basada el nivel de proactividad medioambiental que muestran las empresas (objetiv11), mientras que las columnas muestran el grupo que se predijo sobre la base de la función discriminante. Las empresas en la diagonal principal tienen predicciones correctas (en negrita), mientras que las otras celdas representan las empresas mal clasificadas.

Si cada grupo está compuesto por igual número de respuestas sin ninguna información previa adicional, uno puede asignar al azar las empresas en los dos grupos con una probabilidad de asignación correcta del $50 \%$. En nuestro caso, puesto que las proporciones de cada grupo no son iguales, un criterio de selección proporcional se puede utilizar para evaluar la capacidad predictiva de un modelo discriminante (Morrison, 1969, Huberty, 1984, Perreault et al, 1979) y (Hair et al., 1998). El criterio selección proporcional para un modelo discriminante se puede definir como $\Sigma_{\mathrm{i}}={ }_{1, \mathrm{~K}}\left(\mathrm{p}_{\mathrm{i}}\right)^{2}$ donde, $\mathrm{p}_{\mathrm{i}}$ representa la probabilidad de clasificar correctamente una empresa elegida al azar se clasifican en el grupo i. Las probabilidades $\left(\mathrm{p}_{\mathrm{i}}\right)$ se puede calcular simplemente haciendo una relación del número de observaciones por grupo con respecto al tamaño de la muestra total. Las probabilidades esperadas para los dos grupos son el 44,7\% y 55,3\% respectivamente. Por lo tanto, el criterio de selección proporcional para la muestra total permitiría acertar el 40,58\% de las veces. Hair et al. (1998) recomiendan, para considerar el modelo discriminante como bueno, que la clasificación debe ser de al menos un $25 \%$ más alto que el criterio de probabilidad proporcional $(1,25 \times 50,56 \%=63,2 \%)$. Como se muestra en el cuadro 5 , la exactitud de la clasificación para el modelo estimado fue de $74,0 \%$, lo que es considerablemente superior a la directriz propuesta de Hair et al. (1998). Hay que destacar que la exactitud de la clasificación del 
modelo discriminante estimado es también mayor que el criterio de máxima probabilidad (la probabilidad de estar en el grupo con el mayor tamaño, grupo 0, de la muestra que es del 55,3\%) (Hair et al., 1998).

\section{5.- Conclusiones}

Se puede concluir que se verifica la hipótesis planteada, ya que los resultados del análisis empírico demuestran la existencia de una relación directa entre las empresas clasificadas en el grupo 1 y 2 (Alta y media proactividad medioambiental) y las actividades de mejora continua e innovación. Los factores estudiados que con influencia más directa en la proactividad medioambiental son por una parte la búsqueda de innovaciones internas y la búsqueda de una mejora en la estabilidad y calidad del empleo. El primero está estrechamente ligado con las actividades de mejora continua: actividades de reducción de consumo energético, de consumo de materiales, reducción de costes, incremento de flexibilidad y capacidad. De esta forma las empresas orientadas a realizar actividades de mejora continua muestran también una mayor orientación medioambiental, verificando la hipótesis planteada.

El segundo factor es un objetivo que subyace en cualquier programa de mejora continua. Las empresas destinan recursos a mejora continua con el objetivo de ganar competitividad y así garantizar la viabilidad de la empresa en el largo plazo. A su vez, el mantenimiento de acciones de mejora continua requieren de personal estable que conozca en profundidad los procesos y que adquiera cada vez más habilidades y competencias, siendo estas características indisolubles de cualquier sistema de mejora continua. Por tanto, en este estudio se ha comprobado que las empresas que tienen entre sus objetivos a la hora de realizar innovaciones o mejoras, el desarrollo y estabilidad de sus trabajadores, también se preocupan más por los aspectos medioambientales, verificando de nuevo la relación existente entre las actividades de mejora continua y la orientación medioambiental de las empresas.

La aplicación del trabajo es evidente, las empresas que logren mejorar su orientación medioambiental estarán actuando directamente sobe la mejora continua y la capacidad innovadora y viceversa, ya que la relación entre estos tres conceptos ha sido contrastada

\section{Agradecimientos}

Los autores agradecen el apoyo económico recibido de la Universitat Politècnica de València a traves del proyecto"Impacto de las prácticas innovadoras en el performance medioambiental de la empresa: identificación de factores moderadores" (PAID-06-2011-1879) y también al Ministerio de Economia y Competitividad por su apoyo a través del proyecto (EC02011-27369).

\section{Referencias.}

Achen, Christopher H. (1982). Interpreting and using regression. Series: Quantitative Applications in the Social Sciences, No. 29. Thousand Oaks, CA: Sage Publications.

Albors, J. (2002), Pautas de innovación tecnológica industrial en una región intermedia. El caso de la Comunidad Valenciana, Economía Industrial, 346, 135-146.

Albors-Garrigós, J., Hervás-Oliver, J. Segarra-Oña, M. (2009), Análisis de las prácticas de mejora continua en España barreras y facilitadores, Economía Industrial, 373, 185-195.

Angell, L., Klassen, R. (1999), Integrating environmental issues into the mainstream: an agenda for research in operations management Journal of Operations Management 17, 575-598

Aragón-Correa, J. A., (1998), Strategic proactivity and firm approach to the natural environment. Academy of Management Journal 41(5), 556-567

Aragón-Correa, J. A., Hurtado-Torres N, Sharma S, García-Morales V. (2008), Environmental strategy and performance in small firms: A resource-based perspective, Journal of Environmental Management, 86, 1, 88-103.

Banerjee, S. B., (2002), Corporate environmentalism. The Construct and its Measurement. Journal of Businss Review, Vol. 55, 2002. pp. 177-191

Bansal, P., Roth, K., (2000), why companies go green: a model of ecological responsiveness. Academy of Management Journal, 43, 4, 717-736.

Berry, William D. (1993). Understanding Regression Assumptions. Series: Quantitative Applications in the Social Sciences, No. 92. Thousand Oaks, CA: Sage Publications

Bessant, J., Burnell, J., Harding R., Webb S., (1993), Continuous Improvement in British Manufacturing. Technovation, 13, 4, 241-254.

Bessant, J. (1998), Developing Continuous Improvement Capability. International Journal of Innovation Management, 2, 4, 409-429. 
Bessant, J., Francis, D., (1999), Developing Strategic Continuous Improvement Capability, International Journal of Operations \& Production Management 19, 11, 1106-1119.

Bhuiyan, N. Baghel, A. (2005). An overview of continuous improvement: from the past to the present. Management Decision Vol. 43 No. 5, 2005 pp.761-771

Bond, T. C., (1999), The Role of Performance Measurement in Continuous Improvement. International Journal of Operations \& Production Management, 19, 12, 1318-1334.

Bonilla Priego, M. J., Aviles palacios, C. (2008). Analysis of Environmental Statements Issued by EMAS-Certified Spanish Hotels. Cornell Hospitality Quarterly, 49, 4 ,381-394

Bravo, R. Fraj, E. Martínez, E. La importancia del factor medioambiental en las estrategias corporativa y de marketing: una aplicación al sector de bienes de consumo. Cuadernos de Estudios empresariales 2005, núm 15 199-224

Buysse, K., Verbeke, A., (2003), Proactive environmental strategies: A stakeholder management perspective. Strategic Management Journal, 24, 453-470.

Churchill, G.A., 1979. A paradigm for developing better measures of marketing constructs. Journal of Marketing Research 16 (2), 64-73.

Cilleruelo-Carrasco, E., Sánchez-Fuente, F., Etxebarría-Robledo, B. (2008), Compendio de definiciones del concepto innovación realizadas por autores relevantes: diseño híbrido actualizado del concepto. Dirección y Organización, 36, 61-68.

Clarkson PM, Li Y, Richardson GD, Vasvari FP, (2011), Does it really pay to be green? Determinants and consequences of proactive environmental strategies. J. Account Public Policy 30, 122 144.

Damanpour, F. Gopalakrishnan, S., (2001), The dynamics of the adoption of product and process innovations in organizations. Journal of Management Studies, 38, 1, 45-65.

Darnall, N., Jolley, G. J., Handfield, R. (2006), Environmental Management Systems and Green Supply Chain Management: Complements for Sustainability? Business Strategy and the Environment, 18, 30-45.

Darnall, N., Henriques, I., Sadorsky, P., (2010), Adopting proactive environmental strategy: The influence of stakeholders and firm size. Journal of Management Studies, 47, 1072-1094.

Davenport, T. H. (1993): Process Innovation. Boston, MA.: Harvard Business School Press.

De Benito-Valencia, C.M., (2000), La mejora continua en la gestión de calidad. Seis sigma, el camino para la excelencia, Economía Industrial, 331, 59-66.

De Ron, A., (1998), Sustainable production the ultimate result of a continuous improvement. International Journal of production economics, 56-57, 99-110.

Delmas M, Hoffmann VH, Kuss M (2011), Under the tip of the Iceberg: Absorptive Capacity, Environmental Strategy, and competitive Advantages Business and Society 50(I) 116-154

Esty, D. C., Winston, A. S., (2006), "Green to Gold, How smart companies use environmental strategy to innovate, create value, and build competitive advantage", John Wiley and Sons, Hokoben, New Jersey.

Gavrilescu, M. (2002), Risk assessment and management - tools for Sustainable development, Environmental Engineering and Management Journal, 1, 1, 3-20

Gadenne DL, Kennedy J, Mckeiver C, (2009) An empirical Study of environmental Awareness and Practices in SMEs. Journal of Business Ethics 84, 45-63

García-Sabater J, Marín-García J, 2009, Facilitadores y barreras para la sostenibilidad de la mejora continua: Un estudio cualitativo en proveedores del automóvil de la Comunidad Valenciana. Intangible Capital, 2009 - 5(2):183-209 - ISSN: 1697-9818 doi: 10.3926/ic.2009.v5n2.p183-209 New York.

Gee, S. (1981). Technology transfer, innovation \& international competitiveness. Wiley and Sons,

Gertsen, F. (2001): «How continuous improvement evolves as companies gain experience», nternational Journal of TechnologyManagement, Vol. 22, No. 4, pp.303-326.

González-Benito J., González-Benito O. (2005), Environmental proactivity and business performance: an empirical analysis, Omega International. Journal of Management Science, 33, 1, 1-15.

González-Benito J, González-Benito O, (2006), A Review of Determinant factors of Environmental Proactivity. Business Strategy and the Environment 15, 87-102 (2006)

González-Benito J, González-Benito O, 2008, A Study of Determinant Factors of Stakeholder Environmental Pressure Perceived by Industrial Companies. Business Strategy and the Environment 19, 164-181.

González-Benito J, González-Benito O, (2010), A Study of Determinant Factors of Stake Environmental pressure perceived by industrial companies. Business Strategy and the Environment 19, 164-181 
Gupta M, 1994, Environmental management and its impact on the operations function. International Journal of Operations \& Production Management, Vol. 15 No. 8, 1995, pp. 34-51

Hair, J.F., Anderson, R. E., Tatham, R. L., Black, W. C., (1998), Multivariate data analysis: with readings, 5th Ed. Englewood Cliffs, NJ: Prentice-Hall.

Hart, S.L., 1995. A natural-resource-based view of the firm. Academy of Management Review 20, 4., $996-1014$.

Hervás-Oliver, J. L Albors-Garrigós J (2009) The role of the firm's internal and relational capabilities in clusters: when distance and embeddedness are not enough to explain innovation. Journal of Economic Geography 9 (2009) pp. 263-283

Hitchens, D., Thankappan, S., Trainor, M., Clausen, J. \& De Marchi, B. (2005). Environmental performance, competitiveness and management of small businesses in Europe. Royal Dutch Geographical society, KNAG. Vol. 96, No. 5, pp. 541-557.

Huberty C.J., 1984 Issues in the use and interpretation of discriminant analysis. Psychological Bulletin, 95 (1984), pp. 156-171.

Johnson, R.A., Wichern, D. W. (2001), Applied Multivariate Statistical Analysis. $5^{\text {th }}$ Edition, prentice-hall, New Jersey.

King A.A, Lenox MJ (2001) Does It Really Pay to Be Green? An Empirical Study of Firm Environmental and Financial Performance Journal of Industrial Ecology Volume 5, Number 1 105-116

Kline S.J, Rosenberg N, (1986), The positive Sum Strategy: Harnessing technology for Economic Growth . National Academy Press. Washington. D. C.

Marín-García, J. A.; Pardo del Val, M.; Bonavía Martín, T. (2008). La mejora continua como innovación incremental. El caso de una empresa industrial española. Economía Industrial no ${ }^{\circ}$ 368, pp. 155-169

Martín-Castilla J.I. (2007) La consideración de aspectos sostenibles en los enfoques de excelencia. Boletín económico de ICE $\mathrm{n}^{\circ} 2909$.

Martín-Tapia I, Aragón-Correa J, Rueda-Manzanares A, (2010) Environmental Strategy and exports in medium, small and micro-enterprises. Journal of World Business 45, 266-275

Ferrari, G., Mondéjar-Jiménez, J., Vargas - Vargas, M. (2010) Environmental sustainable management of small rural tourist enterprises International Journal of Environmental Research 4, 3, pp. 407-414

Morrow D, Rondinelli D, 2002, Adopting Corporate Environmental Management Systems: Motivations and Results of ISO 14001 and EMAS Certification. European Management Journal Vol. 20, No. 2, pp. 159-171, 2002

Murillo-Luna J, Garcés-Ayerbe C, Rivera-Torres P, (2008) Why do patterns of environmental response differ? A stakeholders' pressure approach. Strategic Management Journal, 29: 1225-1240.

Oakland, J. (1999), Total Organizational Excellence Achieving World Class Performance, Butterworth-Heinemann, Oxford.

Nunnally, J., 1978. Psychometric Theory. McGraw-Hill, New York.

Oslo Manual, (2005) Guidelines for collecting and interpreting innovation data. Third edition, OECD and Eurostat organization for economic co-operation and development statistical office of the European Communities.

Papadopoulos, T (2011) "Continuous improvement and dynamic actor associations: A study of lean thinking implementation in the UK National Health Service", Leadership in Health Services, Vol. 24 Iss: 3 , pp. $207-227$.

Peiró-Signes A, Segarra-Oña M, Miret-Pastor L, Verma L. (2011) An important key for promoting efficient vertical policies. Environmental Engineering and Management Journal, 10 (12), 1893-1901.

Perreault, W. D., Behrman, D. N., Armstrong, G.M, (1979), Alternative approaches for interpretation of multiple discriminant analysis in marketing research. Journal of Business Research, 7, 151-173.

Perrin, B. (1995), Evaluation and future directions for the Job Accommodation Network (JAN) in Canada. Final Report.Employment Policies and Operations, HRDC.

Pianta, M (2003). Innovation and employment, in: I. Faberberg, D. Mowery and R.R. Nelson (Eds), Handbook of Innovation. Oxford University Press (forth) Chapter 22.

Porter, M. Van der Linde, C. (1995) Toward a new conception of the environment competitiveness relationship. Journal of Economic Perspectives Vol 9 No 4 (1995) Pag. 97-118

Schumpeter, J.A. (1939). Business cycles: a theoretical, historical and statistical analysis of the capitalist process. McGraw-Hill, Nueva York. 
Segarra-Oña, M., Peiró-Signes, A., Miret-Pastor, L., Albors-Garrigós, J., (2011a), ¿Ecoinnovación, una evolución de la innovación? Análisis empírico en la industria cerámica española, Boletín de la Sociedad Española de Cerámica y Vidrio, 50, 219-228.

Segarra-Oña, M., Peiró-Signes, A., Albors-Garrigós, J., Miret-Pastor, P.,(2011b) Impact of Innovative Practices in Environmentally Focused Firms: Moderating Factors, Int.J.Environ.Res, 5 425434.

Sharma, S., Vredenburg, H. (1998) Proactive corporate environmental strategy and the development of competitively valuable organizational capabilities. Strategic Management Journal. Vol. 19 pp. $729-753$

Terziovski, M. Power, D. Sohal, A.S (2003) The longitudinal effects of the ISO 9000 certification process on business performance. European Journal of Operational Research 146 (2003) 580-595

Trott P, (2008), Innovation management and new product development. 4th edition. Pearson Education Limited. ISBN 978-0-273-71315-9

Morrison, 1969 D.G. Morrison, On the interpretation of discriminant analysis. Journal of Marketing Research, 62 (1969), pp. 156-163.

Vega-Jurado, J., Gutiérrez-Gracia, A., Fernández-de-Lucio, I. (2009), 1\La relación entre las estrategias de innovación: coexistencia o complementariedad Journal of Technology Management \& Innovation, 4, 3, 74-88. 
CAPÍTULO 7

DISCUSIÓN DE RESULTADOS Y CONCLUSIONES 


\section{1.- Introducción}

En el último capítulo de la presente tesis doctoral se muestran los resultados, las conclusiones principales, sus limitaciones y las futuras líneas de investigación.

La tesis doctoral sigue el proceso de investigación que comenzó hace varios años y que se ha ido materializando con la consecución de los distintos artículos anteriormente presentados. Se ha ido materializando el acercamiento hacia el concepto de la proactividad medioambiental primero a través de los estudios de caso aplicados a los tres sectores industriales estudiados, alimentación, cerámica y automóvil. El caso del automóvil se complementa con un estudio cuantitativo sobre una muestra mayor de empresas, aquellas incluidas en la base de datos Pitec 2008. El posterior estudio cuantitativo sobre los conceptos mejora continua, innovación y compromiso medioambiental de la gerencia indica la relación existente entre dichos tres conceptos. Por último, en el cuarto artículo se revisa la literatura académica de nuevo, incluyendo en este momento aquella que muestra una predisposición menos positiva hacia el concepto de proactividad medioambiental, se contrasta la misma con los resultados obtenidos anteriormente y de esta forma se consiguen obtener una conclusiones mejor fundamentadas.

\section{2.- Resultados}

Los resultados y las conclusiones obtenidas de esta tesis doctoral se abordan según la definición de objetivos hecha en el capítulo 1, en el que se planteaba el objetivo general como la profundización en el concepto de la proactividad medioambiental y su estudio desde el punto de vista de las empresas industriales, en un estudio aplicado fundamentalmente a la Comunidad Valenciana, en el cual se explica cual es el comportamiento de sus industrias con respecto a la proactividad medioambiental y que patrones se pueden identificar en dicho comportamiento. En este apartado una vez planteado el objetivo principal de la tesis se exponen los objetivos específicos y los capítulos de la presente tesis donde se han abordado

En el primer artículo, el correspondiente al capítulo 2 de la tesis se abordan los siguientes objetivos relativos al sector de la alimentación en la Comunidad Valenciana. El primer objetivo es la identificación de facilitadores de la proactividad medioambiental. Este objetivo se subdivide en tres partes: 
1.1.- Comprobar la relación entre el tamaño de la empresa y su proactividad medioambiental para el sector de la alimentación.

Se observa que las empresas grandes tienen un comportamiento medioambiental mejor en comparación con las Pymes. Así lo demuestra el mayor porcentaje obtenido en valor medio por las empresas grandes en su comportamiento medioambiental. Por lo que se puede afirmar que las empresas grandes muestran una mayor proactividad medioambiental que las Pymes.

Sin embargo se ha encontrado un caso de una empresa pequeña con un comportamiento medioambiental comparable e incluso mejor que algunas empresas grandes.

1.2.- Comprobar la relación entre la internacionalización de las empresas y su proactividad medioambiental para las empresas del sector de la alimentación.

Los resultados muestran que las empresas que compiten internacionalmente tienen un comportamiento medioambiental bastante mejor que aquellas que solamente compiten en el mercado español, así lo demuestran los porcentajes obtenidos por la agrupación de las empresas según este criterio.

1.3.- Comprobar la relación entre el compromiso medioambiental de la gerencia y la proactividad medioambiental de las empresas del sector de la alimentación.

Los resultados obtenidos por las empresas con gerencia más comprometida con el medioambiente demuestran que estas tienen un comportamiento mejor en porcentaje que las empresas cuya gerencia no está comprometida con el medioambiente. Además la agrupación de los resultados según este criterio muestra la mayor diferencia entre ellas, lo que demuestra que este factor es el más determinante, más que el tamaño y la internacionalización.

La empresa pequeña encontrada en este sector con un comportamiento medioambiental mayor competía internacionalmente y su gerencia estaba muy implicada con el medioambiente.

2.- Identificación y ponderación según su importancia de los obstáculos para la proactividad medioambiental para el sector de la alimentación. 
El mayor obstáculo para la proactividad medioambiental en el sector de la alimentación es el escaso apoyo financiero, seguido por la falta de apoyo institucional, por la falta de información sobre las herramientas de gestión medioambiental, por la falta de soluciones técnicas y en último lugar por la falta de recursos humanos cualificados.

3.- Identificación y ponderación según su importancia de los beneficios esperados tras la proactividad medioambiental para las empresas del sector de la alimentación.

El mayor beneficio esperado de la proactividad medioambiental en el sector de la alimentación es el prevenir y evitar futuras sanciones, seguido de la mejora de la imagen corporativa, y de los ahorros de costes y beneficios económicos a largo plazo. Con menor importancia le siguen el incremento de la competitividad, la obtención de nuevas oportunidades de negocio y el incremento de clientes. En último lugar se encuentran los ahorros de costes y beneficios económicos a corto plazo.

En el segundo artículo, el correspondiente al capítulo 3 de la tesis se abordan los siguientes objetivos relativos al sector de la cerámica en la Comunidad Valenciana. El primer objetivo es la identificación de facilitadores de la proactividad medioambiental. Este objetivo se subdivide en tres partes:

4.1.- Comprobar la relación entre el tamaño de las empresas y su proactividad medioambiental en el sector de la cerámica.

Las empresas grandes tienen un comportamiento medioambiental mejor en comparación con las Pymes. Así lo demuestra el mayor porcentaje obtenido en valor medio por las empresas grandes en su comportamiento medioambiental. Por lo que se puede afirmar que las empresas grandes muestran una mayor proactividad medioambiental que las Pymes. También en este sector se ha encontrado un caso de una empresa pequeña con un comportamiento medioambiental comparable e incluso mejor que algunas empresas grandes.

4.2.- Comprobar la relación entre la internacionalización de la empresa y su proactividad medioambiental para el sector de la cerámica.

En los resultados se observa que las empresas que compiten internacionalmente tienen un mejor comportamiento medioambiental que aquellas que compiten solamente 
en el mercado español, los porcentajes obtenidos por la agrupación de las empresas según este criterio así lo demuestran.

4.3.- Comprobar la relación entre el compromiso medioambiental de la gerencia y la proactividad medioambiental de las empresas del sector cerámico.

Las empresas con gerencia más comprometida con el medioambiente muestran mejores resultados obtenidos y un comportamiento mejor en porcentaje que las empresas cuya gerencia está menos comprometida con el medioambiente. En este sector sucede también que la agrupación de los resultados según este criterio muestra la mayor diferencia, lo que demuestra que es este factor el más determinante, más que el tamaño y la internacionalización.

La empresa pequeña encontrada en este caso con un mejor comportamiento medioambiental también competía internacionalmente y su gerencia también estaba muy implicada con el medioambiente, como sucedía en el caso similar encontrado en el sector de la alimentación.

5.- Identificación y ponderación según su importancia de los obstáculos para la proactividad medioambiental en el sector cerámico.

El obstáculo para la proactividad medioambiental con una percepción mayor en el sector de la cerámica es la falta de apoyo institucional, seguido por el escaso apoyo financiero, por la falta de información sobre las herramientas de gestión medioambiental, por la falta de soluciones técnicas y en último lugar por la falta de recursos humanos cualificados.

6.- Identificación y ponderación según su importancia de los beneficios esperados tras la proactividad medioambiental en el sector cerámico.

El beneficio mayormente esperado de la proactividad medioambiental en el sector cerámico es el prevenir y evitar futuras sanciones, seguido de la mejora de la imagen corporativa, de los ahorros de costes a largo plazo y la posible obtención de nuevas oportunidades de negocios. En quinto lugar se encuentra la obtención de beneficios económicos. Con menor importancia le siguen los ahorros de costes a corto plazo, el incremento de la competitividad y el incremento de clientes. En último lugar se encuentran los beneficios económicos a corto plazo. 
En el tercer artículo, el correspondiente al capítulo 4 de la tesis se abordan los siguientes objetivos relativos al sector del automóvil en la Comunidad Valenciana. El primer objetivo es la identificación de facilitadores de la proactividad medioambiental. Este objetivo se subdivide en tres partes como en los sectores anteriores:

7.1.- Comprobar la relación entre el tamaño de las empresas del sector del automóvil y su proactividad medioambiental.

Las grandes empresas tienen un evidente comportamiento medioambiental mejor en comparación con las Pymes. Así lo demuestra el mayor porcentaje obtenido por las empresas grandes en su comportamiento medioambiental. Por lo que se puede afirmar que las empresas grandes muestran una mayor proactividad medioambiental que las Pymes. En este sector no se ha encontrado ningún caso de empresa pequeña con un comportamiento medioambiental bueno, como había sucedido en los sectores de la alimentación y la cerámica.

7.2.- Comprobar la relación entre la internacionalización de las empresas del sector del automóvil y su proactividad medioambiental.

Se verifica en los resultados que aquellas empresas que compiten internacionalmente tienen un mejor comportamiento medioambiental en comparación con aquellas que compiten solamente en el mercado español, los porcentajes obtenidos por la agrupación de las empresas según este criterio muestran una evidente diferencia entre ambas.

7.3.- Comprobar la relación entre el compromiso medioambiental de la gerencia y la proactividad medioambiental de las empresas del sector del automóvil.

Todas las empresas cuya gerencia mostraba un mayor compromiso con el medioambiente obtienen mejores resultados y un comportamiento mejor en porcentaje si se comparan con las empresas cuya gerencia muestra un menor compromiso medioambiental. En este sector sucede como en los dos sectores estudiados anteriormente, que la agrupación de los resultados según este criterio muestra la mayor diferencia, lo que demuestra que es este factor en el sector del automóvil el más determinante, más que el tamaño y la internacionalización. 
8.- Identificación y ponderación según su importancia de los obstáculos para la proactividad medioambiental en el sector del automóvil.

El mayor obstáculo para la proactividad medioambiental, con una diferencia muy grande con respecto a los siguientes, es el escaso apoyo financiero, seguido a bastante distancia por la falta de apoyo institucional y la falta de soluciones técnicas. A continuación se percibe la falta de recursos humanos cualificados, y por último y con una percepción muy pequeña la falta de información sobre las herramientas de gestión medioambiental.

9.- Identificación y ponderación según su importancia de los beneficios esperados tras la proactividad medioambiental en el sector del automóvil.

Para las empresas del sector del automóvil, el beneficio mayormente esperado de la proactividad medioambiental es la mejora de la imagen corporativa, seguido por prevenir y evitar futuras sanciones y beneficios económicos a largo plazo. Después se encuentran los ahorros de costes a largo plazo, el incremento de la competitividad y la posible obtención de nuevas oportunidades de negocio. A continuación se encuentra el incremento de clientes y en último lugar están los ahorros de costes y los beneficios económicos a corto plazo.

10.- Comprobar la relación entre el tamaño de la empresa y su proactividad medioambiental a través del estudio cuantitativo.

El estudio cuantitativo verifica la relación entre la variable "Efecto 8", (que mide como es de esencial para compañías innovadoras mejorar su impacto medioambiental) y las empresas grandes. Lo que demuestra que existe una relación directa entre dichas empresas grandes y el comportamiento medioambiental proactivo.

11.- Comprobar la relación entre la internacionalización de la empresa y su proactividad medioambiental a través del estudio cuantitativo.

El estudio cuantitativo verifica que cuanto más capital extranjero tienen las empresas, estas muestran una mayor proactividad medioambiental cuando innovan. Lo que indica dicha relación entre internacionalización y proactividad medioambiental. 
12.- Comparación intersectorial de los patrones de comportamiento y observación de sus similitudes o diferencias entre ellos.

Este objetivo se ha desglosado para su mejor comprensión en tres partes.

\section{1.- Comparación intersectorial de facilitadores.}

El sector del automóvil presenta una peculiaridad con respecto los otros dos sectores estudiados. Dicha peculiaridad es que todas las empresas de la muestra disponían de acreditación medioambiental basada en la ISO 14001. Disponer de la correspondiente acreditación es un requisito que los fabricantes de automóviles piden a las empresas que desean trabajar con ellos. Esta situación plantea el hecho de que sea necesario mirar más profundamente su desempeño, observando su impacto directo con el medioambiente, para poder así evaluar su comportamiento medioambiental. Esta disposición por parte de todas las empresas de la ISO 14001 es a priori positiva. Sin embargo, al analizar el comportamiento durante las entrevistas y su posterior análisis y reflexión, se han encontrado aspectos de comportamiento un tanto paradójicos, que no se corresponderían con empresas acreditadas con la ISO 14001. Parece, esta es la opinión personal del autor, que dichas empresas una vez obtenida la acreditación, se han relajado en su comportamiento y que la importancia de acreditarse no iba más allá de cumplir con el requisito necesario mínimo para trabajar con el fabricante de automóviles en lugar de un cambio más profundo y de mentalidad en lo que al impacto medioambiental se refiere. Se verifica la necesidad de los estudios cercanos de caso cuando se estudia el comportamiento medioambiental, ya que es frecuente encontrar comportamientos no coherentes entre un entusiasmo "verde", que sin embargo no siempre se materializa en acciones igual de "verdes" que el entusiasmo (Gadenne et al. 2009).

Los sectores de la cerámica y de la alimentación son los sectores donde se ha verificado la parte en la que se cuestiona si el tamaño pequeño de una empresa podía considerarse como una barrera para la proactividad medioambiental. En estos sectores se han encontrado casos de empresas pequeñas, con comportamiento medioambiental muy bueno, superando en algunos casos incluso a empresas grandes pertenecientes a dicho sector. Estos casos encontrados presentaban idénticas características internas de las empresas, eran empresas pequeñas que competían internacionalmente y además sus 
gerencias estaban muy motivadas medioambientalmente. Parece que aquí está la clave de estos casos, estas empresas han superado con ilusión y motivación de su gerencia, la menor disponibilidad de recursos que tienen las empresas pequeñas. En el sector del automóvil, por el contrario, no se han encontrado empresas con comportamiento medioambiental alto entre las pymes analizadas.

12.2.- Comparación intersectorial de beneficios.

El análisis comparativo entre los tres sectores industriales estudiados, permite concluir que la percepción de que se pueden obtener beneficios directos como consecuencia de un comportamiento medioambiental proactivo es bastante diferente entre ellos. El sector que percibe más positivamente la obtención de ventajas es el del automóvil $(75,56 \%)$, seguido del de la alimentación $(67,53 \%)$ y del de la cerámica $(54,60 \%)$.

La percepción positiva hacia la obtención de beneficios como consecuencia de un comportamiento medioambiental proactivo es general en el sector del automóvil. Apenas de perciben diferencias entre las empresas grandes y pymes, entre las que compiten internacionalmente y sólo en España, y entre aquellas con gerencia muy implicada medioambientalmente y aquellas no tanto. Todas prácticamente coinciden en que el comportamiento medioambiental proactivo es una fuente de beneficios sobre todo a medio o largo plazo. El único aspecto donde la percepción es un poco diferente es en el corto plazo. Aquellas empresas muy motivadas ven las posibilidades de mejora incluso en el corto plazo, mientras que aquellas que no están tan motivadas no perciben los beneficios a corto plazo.

En el sector de la alimentación no existe tanta unanimidad con respecto a los beneficios. Aquellas empresas más motivadas ven muchas posibilidades de obtención de beneficios a nivel general (75,56\%), sobre todo beneficios económicos (83\%) y ahorro de costes a largo plazo (90\%), mejora de imagen corporativa (88\%) y evitar futuras sanciones $(86 \%)$ mientras que las no tan motivadas ven muchas menos posibilidades a nivel general $(51,48 \%)$ y especialmente pobre con los ahorros de costes en el corto plazo (33\%).

El sector de la cerámica es el que muestra una visión menos optimista hacia los beneficios de la proactividad medioambiental $(54,60 \%)$. Además la visión es bastante 
diferente entre las empresas más motivadas medioambientalmente, las cuales si perciben posibilidades de obtención de beneficios en general $(62,98 \%)$ y sobre todo en las áreas de mejora de la imagen corporativa $(83,20 \%)$, ahorro de costes a largo plazo $(70,80 \%)$ y evitar futuras sanciones $(77,20 \%)$. Mientras que las menos motivadas son mucho más escépticas en general $(31,11 \%)$, incluso en las áreas de mejora de la imagen corporativa y de ahorro de costes a largo plazo (30\%), la percepción es solamente un poco positiva en el área de evitar futuras sanciones (55\%).

12.3.- Comparación intersectorial de obstáculos.

El análisis comparativo entre los tres sectores industriales estudiados, permite concluir que la percepción de los obstáculos hacia un comportamiento medioambiental proactivo es bastante diferente entre ellos.

El sector de la alimentación tiene una percepción mayor de los obstáculos en general $(57,7 \%)$, que el sector de la cerámica $(48,2 \%)$ y que el del automóvil $(48,8 \%)$. Los obstáculos que percibe con mayor intensidad son la falta de apoyo financiero $(72,2 \%)$ y la falta de apoyo institucional $(64,4 \%)$ mientras que la falta de recursos humanos cualificados es el obstáculo que menos se observa $(46,6 \%)$.

El sector de la cerámica percibe como mayor el obstáculo de falta de apoyo institucional $(65,7 \%)$ seguido por la falta de apoyo financiero $(54,2 \%)$. Los que apenas se perciben como obstáculos son la falta de soluciones técnicas $(37,1 \%)$ y la falta de recursos humanos cualificados $(32,86 \%)$.

La percepción en el sector del automóvil es bastante diferente, hay bastante unanimidad en todas las agrupaciones de empresas, en todas coincide la percepción de la falta de apoyo financiero como el mayor obstáculo (80\%), seguido bastante de lejos por la falta de apoyo institucional (48\%) y la falta de soluciones técnicas (48\%). La falta de información sobre las herramientas de gestión medioambiental apenas es percibida como un obstáculo (28\%).

13.- Otro objetivo de esta investigación, a modo de conclusión final, es confirmar si la proactividad medioambiental, además de evidentemente ser buena para el medioambiente, puede proporcionar beneficios a las empresas estudiadas del tejido industrial de la Comunidad Valenciana. 
La corriente que cuestiona en ocasiones la hipótesis "Pays to be green" (Conviene ser verde), propone las siguientes estrategias medioambientales que las empresas pueden adoptar, su aplicación depende de la estructura de la industria en la cual opera la empresa, su posición en dicha industria, los tipos de mercado donde está enfocada y sus capacidades internas.

Estrategia 1: Eco-eficiencia. Consiste en ser eficiente en el uso de los propios recursos energéticos, en disminuir al máximo los desperdicios.

Estrategia 2: Liderazgo más allá del cumplimiento. Consiste en tomar la iniciativa con un mayor compromiso medioambiental, para ello se necesita incluirlo en la estrategia de marketing y basarla en una estrategia de diferenciación medioambiental enfocada hacia clientes o grupos de mercado sensibles.

Estrategia 3: Eco-Marca. Consiste en la diferenciación de marketing basada en los atributos ecológicos de productos.

Estrategia 4: Liderazgo medioambiental. Consiste en ser líderes en productos de orientación ecológica, esta diferenciación permite la obtención de un precio superior por los productos. Esto es aceptable cuando los correspondientes nichos de mercados están preparados para ello.

La primera estrategia propuesta, la de eco-eficiencia, puede recomendarse para prácticamente cualquier tipo de empresa, ya que disminuir el impacto medioambiental a través de ahorro energético o la reducción de residuos suele verse recompensado con ahorros de costes. Si bien algunas circunstancias particulares, pueden ser más beneficiadas con esta actitud. La primera consiste en ser empresas que suministran a otras empresas industriales, como por ejemplo la industria auxiliar del automóvil, La segunda circunstancia es ser empresas que generan desechos, como por ejemplo la industria agroalimentaria. Y la tercera es para aquellas empresas que requieren de alto consumo energético, como la industria de la cerámica (Orsato, 2006). La estrategia de eco-eficiencia, fomenta el desarrollo de capacidades para incrementar la productividad en los procesos productivos disminuyendo el impacto medioambiental y los costes asociados con él.

La segunda estrategia propuesta, la de liderazgo más allá del cumplimiento, podría recomendarse para el sector del automóvil. Desde que a partir de 2002 los grandes fabricantes impusieron la necesidad de la acreditación ISO 14001 para poder 
operar con ellos, dicha acreditación ha dejado de ser un factor diferenciador entre los distintos proveedores. La frontera para obtener una ventaja competitiva a través del medioambiente se ha desplazado hacia un comportamiento medioambiental proactivo mayor.

Las estrategias de eco marca, y de liderazgo medioambiental también podrían sugerirse como posibilidades en aquellas empresas que buscan un cambio en su posicionamiento de mercado aplicable a cualquier sector industrial de los estudiados.

Contrastando estas estrategias con los beneficios que las propias empresas piensan que podrían obtener, podrían desprenderse varias sugerencias de modificación estratégica. Los beneficios de costes a corto y a largo plazo, junto con los beneficios económicos a corto y largo plazo se corresponderían con la estrategia de eco-eficiencia. La mejora de la imagen corporativa se podría identificar con la estrategia de liderazgo más allá del cumplimiento. Y la obtención de nuevas oportunidades de negocio con las estrategias de eco-marca y de liderazgo medioambiental.

14.- Verificar la relación existente entre el compromiso medioambiental de la gerencia y las actividades de mejora continua e innovación.

En el segundo estudio cuantitativo se verifica la relación directa entre las empresas con mayor proactividad medioambiental y las actividades de mejora continua e innovación. Las empresas orientadas a realizar actividades de mejora continua e innovación muestran una mayor orientación medioambiental, verificándose de este modo que los tres conceptos están interrelacionadso y convergen hacia una meta común, la mejora de la competitividad de la empresa.

\section{3.- Conclusiones.}

Se verifica para los sectores industriales estudiados la información referida al tamaño de la empresa como facilitador propuesta por otros autores (González-Benito y González-Benito, 2006; Vargas y Vargas et al. 2010). Sin embargo, el hecho de haber encontrado varios casos de empresas pequeñas con una gran tendencia hacia la proactividad medioambiental ha sido muy revelador, su análisis ha proporcionado información muy valiosa que disminuye a nuestro modo de ver la importancia del factor tamaño grande de la empresa en favor de otras características internas de la empresa estudiadas en las siguientes hipótesis. Además esto permite concluir que 
definitivamente el tamaño pequeño de una empresa no es una barrera infranqueable para la proactividad medioambiental, según afirman Aragón-Correa et al. (2008).

Se verifica que su comportamiento medioambiental es mejor en comparación con aquellas empresas españolas que sólo compiten a nivel nacional. Es bien conocido que la Unión Europea demuestra una mayor concienciación medioambiental que España. Este peor comportamiento medioambiental de las empresas españolas que sólo operan en España, demuestra que el interés por dicho concepto es bastante menor en España que en los países con los cuales tenemos las mayores relaciones comerciales, principalmente la Unión Europea, como afirman Vargas-Vargas et al. (2010). Y verifica que la presión social es claramente un factor motivador, si la sociedad demanda más el cuidado medioambiental, este se tiene en cuenta en mayor medida (GonzálezBenito y González-Benito, 2006). Además se verifica la hipótesis propuesta por Martín-Tapia et al. (2010), que indica que la proactividad medioambiental es una ayuda para las empresas en proceso de internacionalización.

Otra conclusión que se puede extraer es que los tres factores, tamaño, competir internacionalmente e implicación de la gerencia no tienen el mismo peso. Se observa que el factor implicación de la gerencia tiene un mayor efecto en cada uno de los sectores estudiados y también a nivel global, al compararlo con los facilitadores tamaño de la empresa y competir internacionalmente. La agrupación de los resultados según este facilitador así lo indica. Ya que dicha agrupación muestra la mayor diferencia en el comportamiento medioambiental de las empresas estudiadas y el grupo con peor comportamiento medioambiental es aquel cuya gerencia está poco motivada. Se apoya de esta forma la importancia esencial de la gerencia afirmada por González-Benito y González-Benito (2010)

En la parte de la encuesta que hace referencia a los obstáculos de la proactividad medioambiental, se encuentran todos aquellos aspectos que según la literatura académica pueden afectar a las empresas. La pregunta que se ha hecho a las empresas es: ¿En qué medida es un obstáculo para la proactividad medioambiental? Las respuestas se han agregado y los resultados se presentan con un porcentaje, si dicho porcentaje es alto indica que efectivamente se percibe como un obstáculo, y si dicho porcentaje es bajo, la percepción como obstáculo es menor. 
De todos los propuestos, los que se ven como obstáculos en mayor medida son la falta de apoyo financiero $(68,8 \%)$ identificado previamente por Gadenne et al. (2009). Pero además, es importante mencionar la falta de apoyo institucional $(59,9 \%)$. El resto de obstáculos propuestos se perciben en menor medida, como la carencia de información de las herramientas de gestión medioambiental $(44,6 \%)$, la falta de soluciones técnicas $(45,4 \%)$ y la carencia de recursos humanos cualificados $(39,8 \%)$.

Según la agrupación de empresas se observan diferencias en la percepción de algunos de los obstáculos. Por ejemplo el obstáculo falta de apoyo institucional se percibe en menor medida para las empresas grandes $(48,8 \%)$, y para las empresas que compiten sólo en España (45,4\%). El obstáculo falta de información de las herramientas de gestión medioambiental se percibe en mayor medida para las empresas pequeñas $(50,6 \%)$ y aquellas que compiten internacionalmente $(54,6 \%)$.

En la parte de la encuesta que hace referencia a los beneficios de la proactividad medioambiental, se encuentran todos aquellos aspectos que según la literatura académica pueden beneficiar a las empresas con un comportamiento medioambiental proactivo. Las respuestas están agregadas en forma de porcentaje. Así su interpretación puede intuirse de manera más concreta. Un porcentaje alto de un beneficio indica que se ven muchas posibilidades de beneficiarse de él, y un porcentaje bajo indica lo contrario, que no se ven muchas posibilidades de que ser proactivo medioambientalmente pueda suponer la obtención de dicho beneficio. Los resultados mostrados son los siguientes:

El beneficio que con mayor probabilidad se podría obtener de la proactividad medioambiental es evitar futuras sanciones $(81,6 \%)$, seguido por la mejora de imagen corporativa $(81,1 \%)$, por el ahorro de costes a largo plazo $(73,93 \%)$, por beneficios económicos a largo plazo (72,24\%), por la aparición de nuevas oportunidades de negocio $(68,52 \%)$, y por el incremento de la competitividad $(63,65 \%)$. Los beneficios con menor probabilidad de darse son el incremento de los clientes $(54,02 \%)$, el ahorro de costes a corto plazo $(51,15 \%)$ y por último la obtención de beneficios económicos a corto plazo (46,74\%). Las mayores diferencias entre los grupos de empresas se dan entre las empresas con gerencia poco motivada, las cuales ven menores probabilidades de obtención de todos los beneficios, incluso valores muy bajos para ahorro de costes a corto plazo $(37,78 \%)$ e incremento de los clientes $(36,11 \%)$ mientras que las empresas 
con gerencia motivada percibe para los ahorros de costes a corto plazo $(65,02 \%)$ e incremento de los clientes $(66,73 \%)$ valores mucho mayores. Este mismo hecho se da, aunque en menor medida, entre las empresas que compiten a nivel nacional, con respecto al incremento de clientes $(49,05 \%)$ y el ahorro de costes a corto plazo $(42,46$ $\%)$ y las empresas que compiten internacionalmente con respecto al incremento de clientes $(60,48 \%)$ y el ahorro de costes a corto plazo $(59,14 \%)$. Mientras que no se dan estas diferencias entre empresas grandes y pymes.

Tras este análisis de las conclusiones se podría hacer consecuentemente unas sugerencias de mejora.

Esta información y este marco conceptual puede ayudar a los gerentes de las empresas a definir y priorizar acciones de mejora que optimicen el retorno económico de las inversiones medioambientales para transformar dichas inversiones en fuentes de ventaja competitiva. No se pretende en esta tesis disminuir la eficacia y el interés por la certificación ISO 14001, más bien al contrario, se recomienda siempre que sea posible. En este respecto, sobre todo para pequeñas empresas con recursos limitados que tienen dificultades para lograr la acreditación, se sugiere que si la certificación no es posible, esto no debe ser una razón para olvidar que el medioambiente puede ser una fuente de ventaja competitiva. Sistemas sencillos de ahorro de energía o de minimización de residuos siempre pueden ser adoptados, y esto impacta y mejora de forma inmediata la productividad de la empresa.

Como conclusión final de esta investigación, podría proponerse a los responsables de política industrial que merece la pena el apoyo institucional hacia la proactividad medioambiental, porque se pueden obtener beneficios de ella. Este apoyo institucional es a su vez visto como una acción de mejora necesaria por los propios sectores cerámico y de la alimentación, y también aunque en menor medida, por el sector del automóvil. Dicha acción de mejora, es incluso factible y recomendable en la situación actual de crisis. Ya que la concienciación, explicación y motivación, se pueden hacer sin necesidad de acometer grandes desembolsos monetarios. $\mathrm{Y}$ es en aquellos aspectos con potencial de beneficios y poca necesidad de recursos financieros donde primero deberían proponerse las mejoras 


\section{4.- Limitaciones}

Los resultados obtenidos en los estudios cualitativos de caso no se pueden generalizar para otros sectores industriales.

El estudio para la Comunidad Valenciana se ha realizado para los sectores más importantes en términos de exportaciones, pero existen además de estos tres sectores estudiados, el de la alimentación, la cerámica y el automóvil, otros sectores con un peso importante que no han sido estudiados.

De estas principales limitaciones de la tesis se desprenden las futuras líneas de investigación propuestas.

\section{5.- Futuras líneas de investigación}

La presente tesis doctoral, además de contribuir en aspectos claves para el conocimiento y comprensión de la proactividad medioambiental aplicada a los sectores industriales espera abrir nuevas vías a futuras investigaciones que ayuden a promover este importante campo de estudio.

Para obtener una imagen más completa de todo el sector industrial se propone ampliar el estudio de casos a otros sectores industriales con presencia relevante en la Comunidad Valenciana, como el sector del mueble, el sector del juguete y el sector del calzado.

Así mismo, para completar la visión cuantitativa, se propone la realización de estudios de muestras más amplias para los estudios del sector cerámico y de alimentación, así como un estudio teniendo en cuenta todas las empresas industriales.

También sería interesante estudiar estos mismos sectores en otras zonas donde tienen una presencia importante, así se podría comparar el efecto de la distinta localización geográfica para un mismo sector. 


\section{Referencias}

Dubé L, Paré G (2003). Rigor in information systems positivist case research: current practices, trends, and recommendations. Mis Quarterly, Vol. 27, No 4, pp. 597-635

Gadenne DL, Kennedy J, Mckeiver C, (2009) An empirical Study of environmental Awareness and Practices in SMEs. Journal of Business Ethics 84, 45-63

González-Benito J, González-Benito O, (2006), A Review of Determinant factors of Environmental Proactivity. Business Strategy and the Environment 15, 87-102 (2006)

González-Benito J, González-Benito O, (2010) A Study of Determinant Factors of Stake Environmental pressure perceived by industrial companies. Business Strategy and the Environment 19, 164-181

Martín-Tapia I, Aragón-Correa J, Rueda-Manzanares A, (2010) Environmental Strategy and exports in medium, small and micro-enterprises. Journal of World Business 45, 266-275

Orsato RJ, (2006) Competitive environmental strategies: when does it pay to be green? California Management Review Vol. 48, No.2

Vargas-Vargas M, Meseguer-Santamaría ML, Mondéjar-Jiménez J, MondéjarJiménez JA, (2010) Environmental Protection Expenditure for Companies: A Spanish Regional Analysis, International Journal of Environmental Research, 4 (3) 373-378. 
CAPítulo 8

ANEXOS 


\section{1.- Cuestionario de evaluación de la proactividad medioambiental.}

Bloque 1 del cuestionario. Caracterización.

\section{BLOQUE 1 - CARACTERIZACIÓN}

1. Denominación social

2. Número de empleados

$<50$

50-249

$>250$

3. Tipo de empresa (local, nacional, internacional, multinacional)

4. Breve descripción de la actividad

5. Organigrama

ANEXAR

6. Número de titulados superiors

7. Número de titulados medios

8. Tiene departamento propio de Gestión Medioambiental

SI/NO

9. (SI) Breve descripción

10. (NO) ¿Quién se encarga de las tareas SI/NO relacionadas con la gestión medioambiental?

11. ¿Tienen alguna acreditación relacionada con el Medioambiente?

Explicar:

12. ¿Está en marcha algún proceso para conseguirlo?

\section{SI/NO}

Explicar:

SI/NO

Explicar:

13. ¿Tiene implantada su empresa algún SGMA?

SI/NO

Comentarios:

14. ¿Han desarrollado alguna patente relacionada con

SI/NO la actuación medioambiental ${ }^{3}$ ?

Fuente: Elaboración propia

3 Brunnermeier y Cohen (2003) relacionan la innovación en patentes medioambientales con la competitividad internacional. 
Bloque 2 del cuestionario. Clasificación.

\begin{tabular}{|c|c|c|c|c|c|c|}
\hline \multicolumn{7}{|l|}{ BLOQUE 2 - CLASIFICACIÓN } \\
\hline $\begin{array}{l}\text { 15. ¿En qué medida desarrollan actuaciones para } \\
\text { ahorrar energía? }\end{array}$ & 0 & 1 & 2 & 3 & 4 & 5 \\
\hline $\begin{array}{l}\text { 16. ¿En qué medida utilizan productos ecológicos en } \\
\text { sus ciclos productivos? }\end{array}$ & 0 & 1 & 2 & 3 & 4 & 5 \\
\hline $\begin{array}{l}\text { 17. ¿En qué medida desarrollan actuaciones para } \\
\text { ahorrar agua? }\end{array}$ & 0 & 1 & 2 & 3 & 4 & 5 \\
\hline $\begin{array}{l}\text { 18. ¿En qué medida gestionan los residuos derivados de } \\
\text { su actividad? }\end{array}$ & 0 & 1 & 2 & 3 & 4 & 5 \\
\hline 19. ¿En qué medida son sus productos reciclables? & 0 & 1 & 2 & 3 & 4 & 5 \\
\hline $\begin{array}{l}\text { 20. ¿En qué medida desarrollan acciones destinadas a } \\
\text { mejorar la formación en cuestiones ambientales? }\end{array}$ & 0 & 1 & 2 & 3 & 4 & 5 \\
\hline $\begin{array}{l}\text { 21. ¿En qué medida utilizan argumentos ecológicos en } \\
\text { las campañas de marketing? }\end{array}$ & 0 & 1 & 2 & 3 & 4 & 5 \\
\hline $\begin{array}{l}\text { 22. ¿Cuantifican los costes y ahorros ambientales en los } \\
\text { presupuestos internos? }\end{array}$ & 0 & 1 & 2 & 3 & 4 & 5 \\
\hline $\begin{array}{l}\text { 23. ¿Divulgan de manera externa la información sobre } \\
\text { las actuaciones desarrolladas? }\end{array}$ & 0 & 1 & 2 & 3 & 4 & 5 \\
\hline $\begin{array}{l}\text { 24. ¿Divulgan de manera interna la información sobre } \\
\text { las actuaciones desarrolladas? }\end{array}$ & 0 & 1 & 2 & 3 & 4 & 5 \\
\hline 25. Determine su grado de conocimiento de los SGMA & & 1 & 2 & 3 & 4 & 5 \\
\hline 26. Indique el grado de implantación de los SGMA: & & 1 & 2 & 3 & 4 & 5 \\
\hline $\begin{array}{l}\text { 27. Indique en qué grado está de acuerdo con las } \\
\text { siguientes afirmaciones: }\end{array}$ & & & & & & \\
\hline
\end{tabular}


oportunidad para innovar y mejorar.

$\begin{array}{llllll}0 & 1 & 2 & 3 & 4 & 5\end{array}$

Mi empresa aplica sistemas de gestión y prevención medioambiental.

Mi empresa reacciona ante las obligaciones medioambientales y toman decisiones para cumplir la normativa vigente.

En mi empresa cuesta adoptar las medidas necesarias y no existe compromiso con el medioambiente.

En mi empresa la preocupación medioambiental supone una amenaza que dificulta el funcionamiento.

$\begin{array}{llllll}0 & 1 & 2 & 3 & 4 & 5\end{array}$

$\begin{array}{llllll}0 & 1 & 2 & 3 & 4 & 5\end{array}$

$\begin{array}{llllll}0 & 1 & 2 & 3 & 4 & 5\end{array}$

$\begin{array}{llllll}0 & 1 & 2 & 3 & 4 & 5\end{array}$

Bloque 3 del cuestionario.

\section{BLOQUE 3 - INTEGRACIÓN DE LA PROACTIVIDAD MEDIOAMBIENTAL EN LA ESTRATEGIA EMPRESARIAL}

28. Determine el nivel de influencia sobre las decisiones que toman Uds. relacionadas con el medioambiente que tienen:

Socios/Accionistas

Directivos.

Clientes.

Administración Pública a nivel nacional.

Administración Pública a nivel regional.

Administración Pública a nivel local.

Asociaciones de empresarios.

Institutos tecnológicos

Matriz/cadena a la que pertenece

Competidores

Empleados

Proveedores

Otros :

Comentarios adicionales:

29. Considera que para su las actuaciones medioambientales de su empresa supone un obstáculo:

Escaso apoyo financiero.

Falta de apoyo institucional

Falta de información de las herramientas

Falta de recursos humanos cualificados

$\begin{array}{llllll}0 & 1 & 2 & 3 & 4 & 5 \\ 0 & 1 & 2 & 3 & 4 & 5 \\ 0 & 1 & 2 & 3 & 4 & 5 \\ 0 & 1 & 2 & 3 & 4 & 5 \\ 0 & 1 & 2 & 3 & 4 & 5 \\ 0 & 1 & 2 & 3 & 4 & 5 \\ 0 & 1 & 2 & 3 & 4 & 5 \\ 0 & 1 & 2 & 3 & 4 & 5 \\ 0 & 1 & 2 & 3 & 4 & 5 \\ 0 & 1 & 2 & 3 & 4 & 5 \\ 0 & 1 & 2 & 3 & 4 & 5 \\ 0 & 1 & 2 & 3 & 4 & 5 \\ 0 & 1 & 2 & 3 & 4 & 5\end{array}$

Falta de soluciones técnicas. 





ecológicos su empresa puede:

Aumentar su cuota de mercado.

Mejorar la calidad de los productos y procesos.

Entrar en nuevos mercados.

Ser líder del mercado.

Comentarios adicionales:

$\begin{array}{llllll}0 & 1 & 2 & 3 & 4 & 5 \\ 0 & 1 & 2 & 3 & 4 & 5 \\ 0 & 1 & 2 & 3 & 4 & 5 \\ 0 & 1 & 2 & 3 & 4 & 5\end{array}$

33. En su empresa se invierte en mejorar las tecnologías con el objetivo de hacerlas más limpias y respetuosas con el medio ambiente.

34. En su empresa hay implantado un sistema de gestión de la tecnología

35.(SI) Con actuaciones directamente relacionadas con la sostenibilidad medioambiental.

36. Con respecto a los SGMA:

Son aplicables en mi empresa

Son aplicables sólo en grandes empresas

Se aplican sólo si son obligatorios

Contribuyen a un mejor control y toma de decisiones......

Suponen un alto coste.

$\begin{array}{llllll}0 & 1 & 2 & 3 & 4 & 5\end{array}$

Son una inversión necesaria

$\begin{array}{llllll}0 & 1 & 2 & 3 & 4 & 5\end{array}$

$\begin{array}{llllll}0 & 1 & 2 & 3 & 4 & 5\end{array}$

$\begin{array}{llllll}0 & 1 & 2 & 3 & 4 & 5\end{array}$

$\begin{array}{llllll}0 & 1 & 2 & 3 & 4 & 5\end{array}$

$\begin{array}{llllll}0 & 1 & 2 & 3 & 4 & 5\end{array}$

$\begin{array}{llllll}0 & 1 & 2 & 3 & 4 & 5\end{array}$

37. En su opinión el desarrollo sostenible:

Es una utopía.

Viene determinado por la legislación.

Es compatible con el desarrollo industrial

Tiene un alto coste en recursos.

Es un objetivo ya alcanzado

$\begin{array}{llllll}0 & 1 & 2 & 3 & 4 & 5\end{array}$

$\begin{array}{llllll}0 & 1 & 2 & 3 & 4 & 5\end{array}$

$\begin{array}{llllll}0 & 1 & 2 & 3 & 4 & 5\end{array}$

$\begin{array}{llllll}0 & 1 & 2 & 3 & 4 & 5\end{array}$

$\begin{array}{llllll}0 & 1 & 2 & 3 & 4 & 5\end{array}$

38. Valore el compromiso de la dirección con la preservación ambiental

$\begin{array}{llllll}0 & 1 & 2 & 3 & 4 & 5\end{array}$

39. Valore el apoyo que reciben los esfuerzos ambientales por parte de la dirección 


\begin{tabular}{|c|c|c|c|c|c|c|}
\hline $\begin{array}{l}\text { 40. La calidad incluye reducir el impacto medioambiental de } \\
\text { productos y procesos. }\end{array}$ & 0 & 1 & 2 & 3 & 4 & \\
\hline $\begin{array}{l}\text { 41. Valore la implicación de la dirección en la elaboración de } \\
\text { la estrategia medioambiental de la empresa. }\end{array}$ & 0 & 1 & 2 & 3 & 4 & 5 \\
\hline $\begin{array}{l}\text { 42. En su opinión, la estrategia medioambiental está integrada } \\
\text { en el proceso de planificación estratégica de su empresa }\end{array}$ & 0 & 1 & 2 & 3 & 4 & \\
\hline
\end{tabular}

Fuente: Elaboración propia. 
2.- Información referente a la publicación del artículo 1.

Información de la publicación como capítulo de libro de la editorial SpringerVerlag.

\section{About This Chapter}

Title

Do Companies Know Which are the Barriers and Facilitators that Enable Proactive Environmental Orientation of the Industry?

Authors

An empirical study of a low tech industry

- María-del-Val Segarra-Oña ${ }^{(1)}$

- Conrado Carrascosa- López ${ }^{(1)}$

- Baldomero Segura-García-del-Río(1)

Author Affiliations

1. Universitat Politècnica de València, Valencia, Spain

DOI 10.1007/978-3-642-19536-5_29

SpringerLink Date Thursday, June 23, 2011

\section{About This Book}

Title

Information Technologies in Environmental Engineering

Editors

New Trends and Challenges

- Paulina Golinska ${ }^{(1)}$

- Marek Fertsch ${ }^{(2)}$

- Jorge Marx-Gómez ${ }^{(3)}$

Editor Affiliations

1. Poznan University of Technology, Strzelecka 11, Poznan, 60-965 Poland

2. Poznan University of Technology, Strzelecka 11, Poznan, 60-965 Poland

3. , Dept. für Informatik, Universität Oldenburg, Ammerländer Heerstr. 114118, Oldenburg, 26129 Germany

Collection

Earth and Environmental Science

Subjects

- Environment

- Environmental Engineering/Biotechnology

Copyright Year 2011

DOI 10.1007/978-3-642-19536-5

ISBN 978-3-642-19535-8 (Print) 978-3-642-19536-5 (Online)

Additional Links 
- About This Book

Publisher

Springer Berlin Heidelberg

SpringerLink Date

Thursday, June 23, 2011

\section{About This Book Series}

Title Editors

Environmental Science and Engineering

- R. Allan

- U. Förstner

- $\underline{\text { W. Salomons }}$ 


\section{3.- Información referente a la publicación del artículo 2. Carta consentimiento de publicación del capítulo e información del libro de la editorial Springer-Verlag.}

\section{Consent to Publish}

\section{黛 Springer}

Series: EcoProduction. Environmental Issues in Logistics and Manufacturing

Title of Book/Volume/Conference: EcoProduction \& Logistics - emerging trends and business practices

Editor(s) name(s): Paulina Golinska

Title of Contribution: IS IT POSSIBLE TO GENERATE ADDED VALUE THROUGH A HIGHER ENVIRONMENTAL PROACTIVITY ORIENTATION? A PRACTICAL ANALYSIS OF THE SPANISH CERAMIC INDUSTRY

Author(s) full name(s): Conrado Carrascosa-López, María-del-Val Segarra-Oña, Ángel PeiróSignes, Luis Miret-Pastor, Baldomero Segura-García-del-Río

Corresponding Author's name, address, affiliation and e-mail: Conrado Carrascosa-López Management Department, 7D Building, Camino de Vera, $\mathrm{s} / \mathrm{n}$, Universitat Politècnica de València,46022, Valencia, Spain. concarlo@upvnet.upv.es

When the Author is more than one person the expression "Author" as used in this agreement will apply collectively unless otherwise indicated.

\section{\$ 1 Rights Granted}

Author hereby grants and assigns to Springer-Verlag GmbH Berlin Heidelberg (hereinafter called Springer) the sole, transferable right to reproduce, publish, distribute, transmit, make available or otherwise communicate to the public, publicly perform, archive, store, lease or lend and sell the Contribution or part thereof individually or together with other works in any language, in all revisions and versions (including soft cover, book club and collected editions, anthologies, advance printing, reprints or print to order, microfilm editions, audiograms and videograms), in all forms and medin of expression including in electronic form (including offline and online use, push or pull technologies, use in databases and networks for display, print and storing on any and all stationary or portable end user devices, e.g. text readers, audio, video or interactive devices, and for use in multimedia or interactive versions as well as for the display or transmission of the works or parts thereof in data networks or search engines), in whole, in part or in summarized form, in each case as row hrown or devcloped in the fiture, throughout the world and during the term of copyright protection as dew knew in dercic defined in domestic law, including the right to grant further time-limited or permanent rights. For purposes of use in electronic form, Springer may adjust the Contribution to the respective form of use and include links or otherwise combine it with other works. Springer may use the Contribution for advertising purposes. Springer will take, either in its own name or in that of Author, any necessary steps to protect these rights against infringement by third parties. It will have the copyright notice inserted into all editions of the Contribution according to the provisions of the Universal Copyright Convention (UCC) and dutifully take care of all formalities in this connection, either in its own name or in that of Author.

If the Contribution was performed under U.S. Government contract, but Author is not a U.S. Government employee, Springer grants the U.S. Government royalty-free permission to reproduce all or part of the Contribution and to authorize others to do so for U.S. Government purposes. If Author is an officer or employee of the U.S. Government reference will be made to this status on the signature page.

$\$ 2$ Rights retained by Author

Author retains, in addition to uses permitted by law, the right to communicate the content of the Contribution to other scientists, to share the Contribution with them in manuscript form, to perform or present the Contribution or to use the content for non-commercial internal and educational purposes, provided the Springer publication is mentioned as the original source of publication in any printed or electronic materials Author retains the right to republish the Contribution in any collection consisting solely of Author's own works without charge and subject only to notifying Springer in writing prior to such publication of the intent to do so and to ensuring that the publication by Springer is properly credited and that the relevant copyright notice is repeated verbatim. 


\section{$\$ 3$ Warranties}

Author warrants that the Contribution is original except for such excerpts from copyrighted works (including illustrations, tables, animations and text quotations) as may be included with the permission of the copyright holder thereof, in which case(s) Author is required to obtain written permission to the extent necessary and to indicate the precise source. Springer has the right to permit others to use individual illustrations within the usual limits.

Author warrants that he/she has power to grant the rights in accordance with Clause "Rights Granted", that he/she has not assigned such rights to third parties, that the Contribution has not heretofore been published in whole or in part, contains no libelous statements and does not infringe on any copyright, trademark, patent, statutory rights or proprietary rights of others, including rights obtained through licenses; and that Author will indemnify Springer against any cost, expenses or damages for which Springer may become liable as a result of any breach of this warranty.

\section{\$4. Delivery of Contribution and Publication}

Author agrees to deliver to the responsible Editor(s) on a date to be agreed upon the manuscript created according to the Instructions for Authors.

Springer agrees to publish the said Contribution at its own cost and expense.

\section{\$5 Author's Discount}

Author is entitled to purchase for his/her personal use (directly from Springer) other books published by Springer at a discount of $331 / 3 \%$ off the list price as long as there is a contractual arrangement between Author and Springer. Resale of such copies or of free copies is not permitted.

\section{\$6 Governing Law and Jurisdiction}

This agreement shall be governed by, and shall be construed in accordance with, the laws of the Federal Republic of Germany. The courts of Berlin, Germany shall have the exclusive jurisdiction.

Corresponding Author signs for and accepts responsibility for releasing this material on behalf of any and all Co-Authors.

\section{Signature of Corresponding Author:}



Date

$\square$ I'm an employee of the US Government and transfer the rights to the extent transferable (Title 17 \$105 U.S.C. applies)

GPU/PS

0152.E-GE $11-12 / 2010$ 


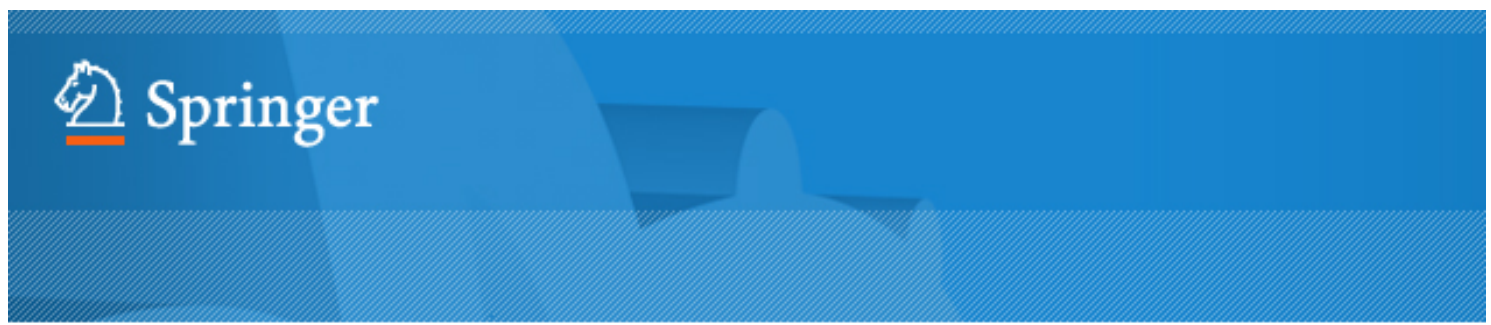

HOME : MY SPRINGER $\quad$ FACHBEREICHE $\quad$ SERVICES $\quad$ IMPRINTS \& VERLAGE $\quad$ ÜBER UNS

7) Umwelttechnik whd-physik Home : Umweitwissensohaften ? Ummeittechnik und -physik FACHGEbIETE $\vdots$ ZEITSCHRIFTEN $\quad$ NEUERSCHEINUNGEN :

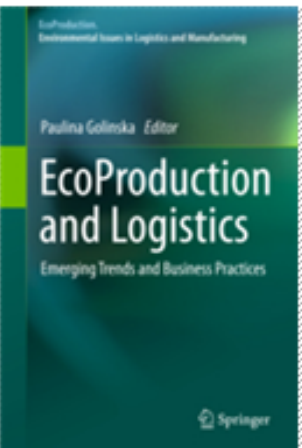

\section{EcoProduction and Logistics}

Emerging Trends and Business Practices

Series: EcoProduction

Golinska, Paulina (Ed.)

2012, 2012, CCCXCl, 6 p. 104 illus.

Hardcover, ISBN 978-3-642-23552-8

Due: June 30, 2012

$139,05 € \nabla$ 䨌

Tweet

ABOUT THIS BOOK

I: Emphasizes the crucial aspects of implementation of the environmental conscious manufacturing practice to existing industrial systems

:1: Provides practical application of tools and methods for solving business practice problems

:I. Includes case studies which guide readers in areas outside of their expertise

Environmentally conscious manufacturing is a new business approach which focuses on the most efficient and productive use of raw materials and natural resources in order to minimize footprints on the natural environment. The book aims to provide the state of the art as well as new ideas of the environmental conscious operations management. The contributors present and discuss such fields as: eco-friendly production technologies; recycling, remanufacturing \& reuse, waste reduction \& management. The scope of topics discussed in this book covers also pollution prevention, energy efficiency, material substitution. The authors describe the problems of environmental management in complex manufacturing systems

Content Level " Research

Keywords » Environmental Management - Recycling - Remanufacturing - Sustainable Manufacturing

Related subjects » Environmental Engineering and Physics - Environmental Management Production \& Logistics - Sustainable Development 


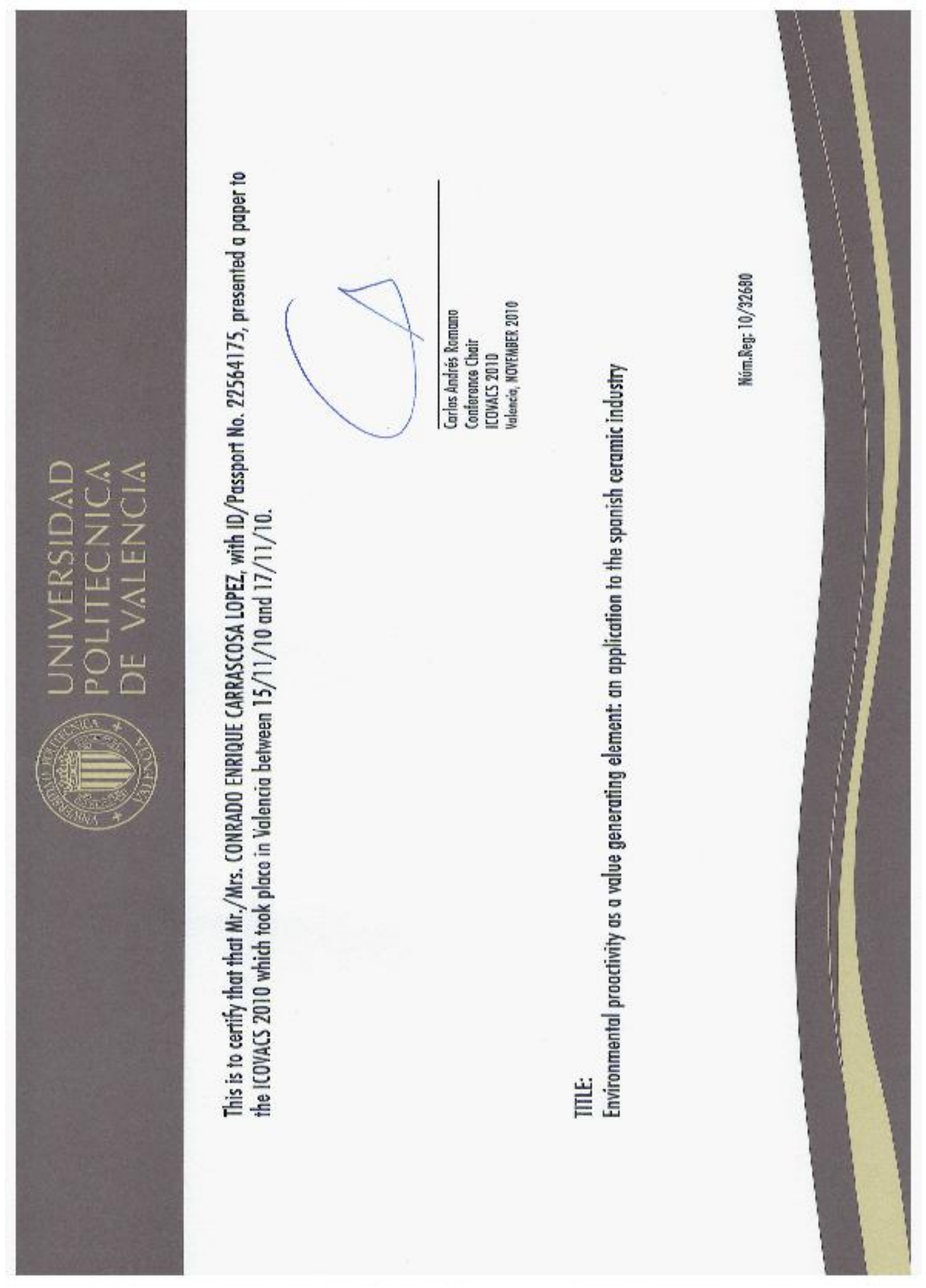


4.- Información referente a la publicación del artículo 3.

Indicios de calidad información de la revista.

El artículo ha sido publicado en la Revista Environmental Engineering and Management Journal, ISSN:1582-9596, On-line ISSN:1843-3707, volumen 10 (número 12, diciembre 2011), comprendiendo las páginas 1821 hasta 1830. Dicha revista se encuentra incluida en la base de datos del ISI Thompson como JCR en el SCIENCE CITATION INDEX, con un factor de impacto de 1.435 en 2010. 


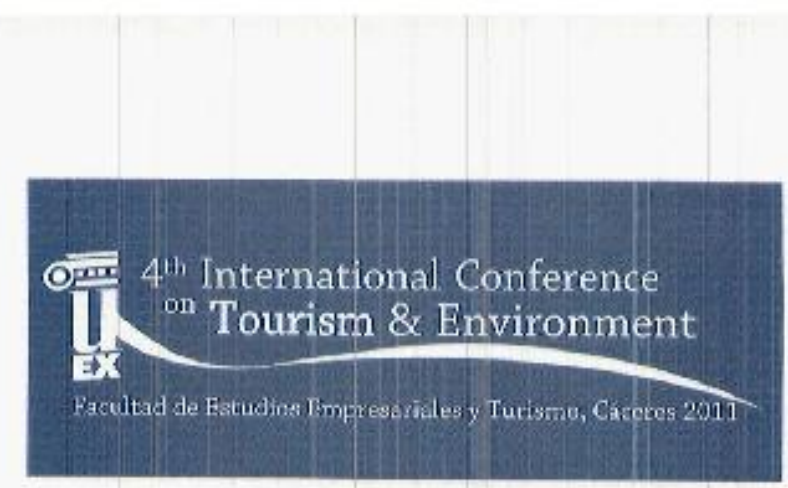

UNIVERSITY OF EXTREMADURA -SHain-

\section{CERTIFICATE OF PRESENTATION}

\section{This is to certify that}

\section{Prof. Conrado Carrascosa López}

Was co-author of the paper entitled «EMPIRICAL ANALYSIS OF THE INTEGRATION OF ENVIRONMENTAL PROACTIVITY INTO MANAGERIAL STRATEGY. IDENTIFICATION OF BENEFITS, DIFFICULTIES AND FACILITATORS AT THE SPANISH AUTOMOTIVE INDUSTRY $>$ presented at the 4th International Conference on Tourism and Environment, heid in University of Extremadura, Cáceres (Spain), 28-30 September 2011.

Cáceres, 30 of Septembrer 2011






\section{5.- Información referente a la publicación del artículo 4.}

\section{Carta aceptación para publicación del artículo e información de la revista.}

De: Clute Institute Payments [mailto:payments@ cluteinstitute.com]

Enviado el: viernes, 02 de marzo de 2012 12:45

Para: maseo@omp.upv.es

Asunto: Journal Manuscript Acceptance IBER 4820

Dear Professor:

Based on the recommendations of two independent reviewers and the editor regarding current editorial requirements, your manuscript entitled "Environmental Proactivity In Manufacturing Industries: Is It Valuable?" has been accepted for publication in the International Business \& Economics Research Journal. This acceptance is valid for one year.

Page fees for journal publication will be invoiced separately via email. As a condition of publication, the authors must assign copyright and publication rights to the Clute Institute to provide us with full copyright protection and the right to disseminate the manuscript to the widest possible readership. Authors retain full, but non-exclusive rights to their manuscript. This means that authors may use their manuscript in any way they see fit without obtaining permission from the Clute Institute provided that appropriate credit to the Clute Institute is noted.

An estimated publication date will be emailed to you following payment of the page fees. A formatted draft of your manuscript will be emailed for approval to each author prior to publication, and at the time of publication, each author will receive a complimentary PDF copy of their manuscript. Hard copies of the journal may be purchased for $\$ 20$ per copy. Please contact us to place your order.

Please be sure that we are provided with email addresses for each author. For journal rating purposes, we are including email addresses in the author biographies.

Congratulations on your successful acceptance, and thank you for allowing the Clute Institute to publish your manuscript.

Ryan

Ryan Kauffman

The Clute Institute

6901 S Pierce St., Suite 239

Littleton, CO 80128

Tel: 303-904-4750, Fax: 720-259-2420

Payments@CluteInstitute.com

www.CluteInstitute.com 


\begin{tabular}{|c|c|}
\hline Main title [English] & $\begin{array}{c}\text { International Business \& Economics Research } \\
\text { Journal }\end{array}$ \\
\hline Abbreviation title & IBER \\
\hline p-ISSN & $1535-0754$ \\
\hline e-ISSN & 2157-9393 \\
\hline URL & http://journals.cluteonline.com/index.php/IBER/issue/archive \\
\hline Country & USA \\
\hline Frequency & Monthly \\
\hline Insert to IC & $2008-10-29$ \\
\hline Year publication & 2002 \\
\hline $\begin{array}{l}\text { Year publication } \\
\text { electronic }\end{array}$ & 2008 \\
\hline Editor in Chief & Ronald C. CLute \\
\hline Fulltext language & English \\
\hline Abstract language & English \\
\hline $\begin{array}{l}\text { Published by } \\
\text { electronic }\end{array}$ & Clute Institute \\
\hline $\begin{array}{c}\text { Journal } \\
\text { description [English] }\end{array}$ & $\begin{array}{c}\text { The International Business \& Economics Research Journal welcomes articles } \\
\text { in all areas of international business and economics research. Both } \\
\text { theoretical and applied manuscripts will be considered for publication. } \\
\text { Theoretical manuscripts must provide a clear and interesting international } \\
\text { application. }\end{array}$ \\
\hline & Extended Section | IC Value \\
\hline IC Value 2010 & not indexed \\
\hline Current status 2011 & Evaluation pending \\
\hline \multirow[t]{2}{*}{ ICV history } & $\begin{array}{l}\text { Voucher required INSERT }[2009] \\
\text { Voucher required }^{\text {INSERT }}[2008]\end{array}$ \\
\hline & Extended Section | Contacts and Addresses \\
\hline $\begin{array}{l}\text { Editorial office } \\
\text { address }\end{array}$ & Voucher required INSERT \\
\hline Editor in Chief & $\begin{array}{c}\text { Ronald C. CLUTE } \\
\text { E-mail: Voucher required INSERT } \\
\text { Telefon: Voucher required INSERT }\end{array}$ \\
\hline \multirow[t]{2}{*}{$\begin{array}{l}\text { Published by } \\
\text { electronic }\end{array}$} & $\begin{array}{c}\text { Clute Institute } \\
\text { Voucher required INSERT } \\
\text { E-mail: Voucher required INSERT }\end{array}$ \\
\hline & Extended Section | Scientific profile \\
\hline
\end{tabular}




\section{6.- Información referente a la publicación del artículo 5.}

\section{Escuela de Administración de Empresas \\ Revista Tec Empresarial}

RTE-02-12

28 de febrero de 2011

\section{Constancia}

A quien corresponda:

Por la presente hago constar que el artículo "Explorando la relación entre mejora continua, innovación y compromiso medioambiental de la gerencia, un estudio empirico", ha sido recibido y aceptado para evaluación en la revista Tec Empresarial. La fecha de recepción que consta en muestros registros es 17 de enero y el proceso de revisión puede tomar hasta un máximo de 12 semanas.

El citado artículo fue presentado por: Conrado Carrascosa-López, Angel Peiró-Signes, y María del Val Segarra-Oña, con afiliación institucional a la Universitad Politécnica de Valencia, España y al International Network for Economic Research on Tourism and Environment.

La revista Tec Empresarial es emitida por la Escuela de Administración de Empresas del Instituto Tecnológico de Costa Rica. Su ISSN es 1659-2395, se publica cuatrimestralmente y se halla indexada/registrada en Latindex, Dialnet, CLASE y EBSCO.

Se emite la presente a solicitud de los interesados

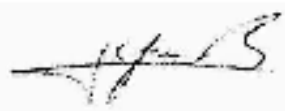

Juan Carlos Leiva Bonilla. PhD. Director.

Revista Tec Empresarial, Escuela de Administración de Empresas

Instituto Tecnológico de Costa Rica

Tel. (506) 2550-9052

Correo E: jleiva@itcr.ac.cr

PB: 159-7050 Costa Rica 
GoBIERNO MINISTERIO

DE ESPAÑA DECIENCIA

E INNOYACIÓN

(ECO2010:17.318)
UNTERIIAT

POLITECNICA

DE VALENCIA



TALLER DE ESTRATEGIA EMPRESARIAL 2012

ACEDE

Valencia, 25 de enero de 2012

\section{CERTIFICA:}

Que D. Conrodo Carroscasa López participó en colidoó de Presentación con Poster al Taller ACEDE de ia Sección de Estrategia Empresarial, tituiado "CONTEMPORARY CONCEPTS IN STRATEGIC MANAGEMENT: UNFOLOING OPEN INNOVATION, ABSORPTIVE CAPACITY, CLUSTERS AND MANAGEMENT INNOVATION", celebrado en Valencia, el 25 de Enero de 2012 en la Facultad de ADE, Departamento de Organización de Empresas, de la Universidad Politécnica de Valencia.

Y para que conste donde convenga,

Atentamente

Dirección del Taller

Dr. D. José Luis Ifervis Oliver

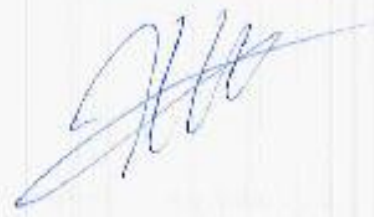

Presidencia

Dr. César Camisón Zorneza

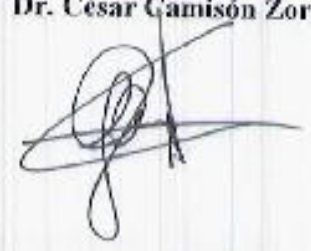

